\title{
Sediment Studies at Bikini Atoll Part 2. Inventories of Transuranium Elements in Surface Sediments
}

\author{
Victor E. Noshkin \\ Rodney J. Eagle \\ Kai M. Wong \\ William L. Robison
}

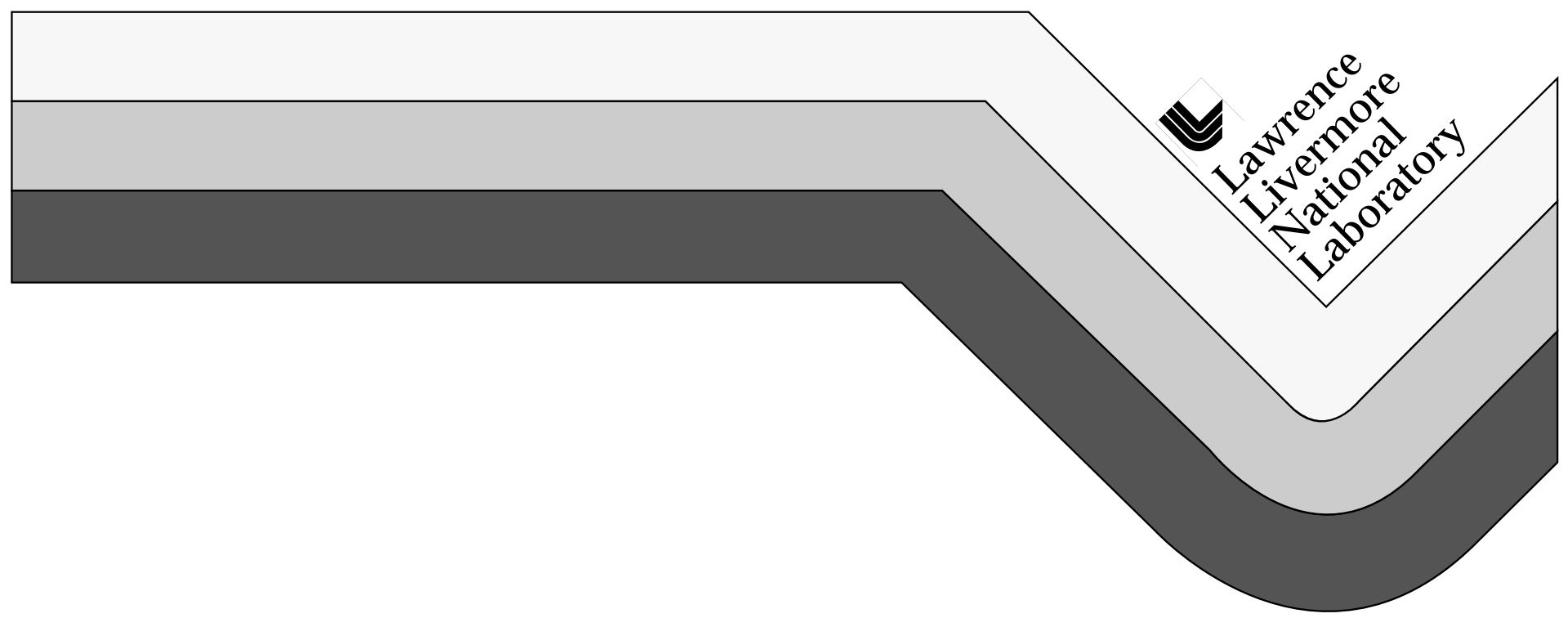




\section{DISCLAIMER}

This document was prepared as an account of work sponsored by an agency of the United States Government. Neither the United States Government nor the University of California nor any of their employees, makes any warranty, express or implied, or assumes any legal liability or responsibility for the accuracy, completeness, or usefulness of any information, apparatus, product, or process disclosed, or represents that its use would not infringe privately owned rights. Reference herein to any specific commercial product, process, or service by trade name, trademark, manufacturer, or otherwise, does not necessarily constitute or imply its endorsement, recommendation, or favoring by the United States Government or the University of California. The views and opinions of authors expressed herein do not necessarily state or reflect those of the United States Government or the University of California, and shall not be used for advertising or product endorsement purposes.

This report has been reproduced directly from the best available copy.

Available to DOE and DOE contractors from the Office of Scientific and Technical Information P.O. Box 62, Oak Ridge, TN 37831

Prices available from (615) 576-8401, FTS 626-8401

Available to the public from the

National Technical Information Service

U.S. Department of Commerce

5285 Port Royal Rd.,

Springfield, VA 22161

Work performed under the auspices of the U.S. Department of Energy by Lawrence Livermore National Laboratory under Contract W-7405-ENG-48. 
UCRL-LR-129379

Distribution Category

Sediment Studies at Bikini Atoll Part 2.

Inventories of Transuranium Elements in Surface Sediments

\author{
VictorE. Noshkin \\ Rodney J. Eagle \\ Kai M. Wong \\ WilliamL.Robison
}

Manuscript date: October 1997 



\section{Contents}

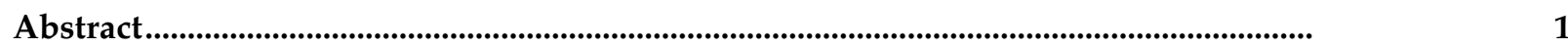

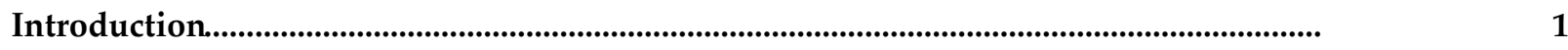

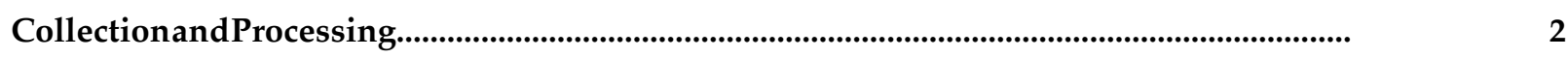

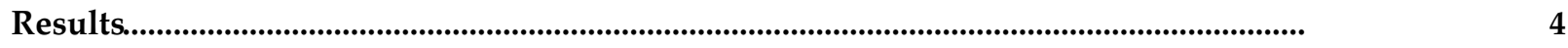

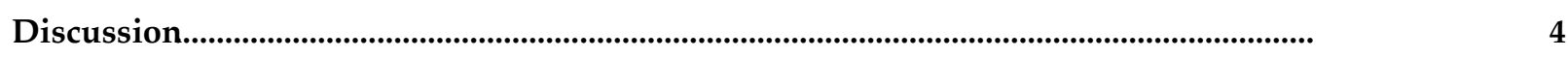

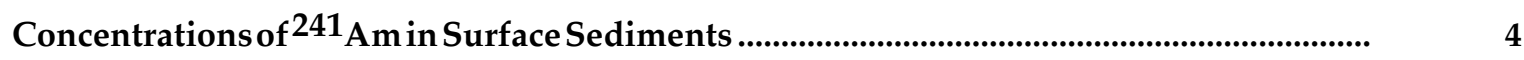

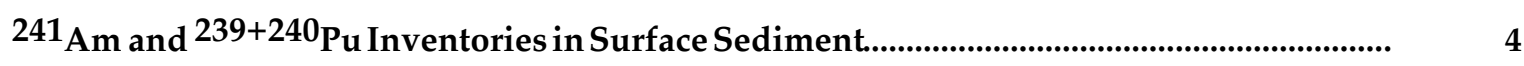

Distribution with Depth in Sediment Column ........................................................................... 10

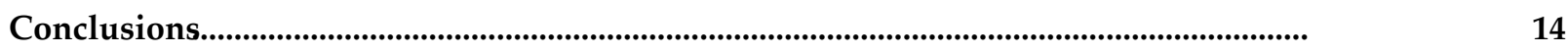

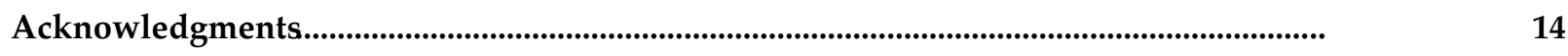

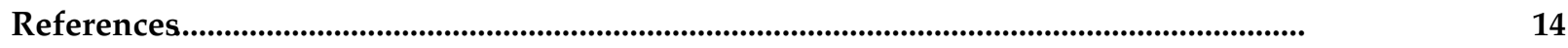

Appendix A: Description of Bikini Lagoon Surface Sediments $(0-2.5 \mathrm{~cm})$

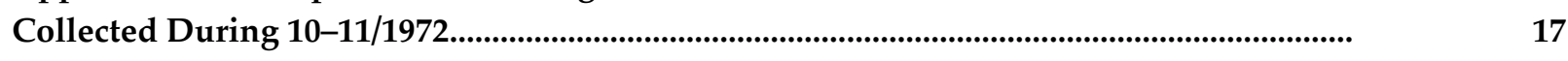

Appendix B: Description of Bikini Lagoon Sediment Cores Collected

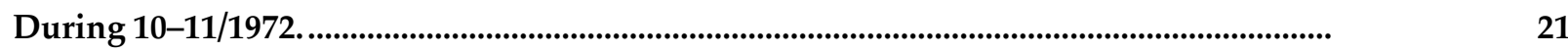

Appendix C: Description of Bikini Lagoon Surface Sediments (0-2 cm)

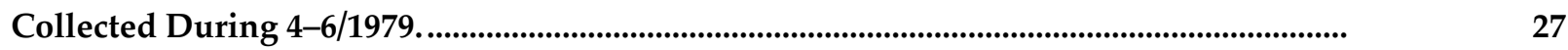

Appendix D: Description of Bikini Lagoon Surface Sediments $(0-4 \mathrm{~cm})$

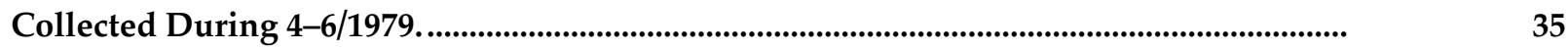

Appendix E: Concentration of ${ }^{241} \mathrm{Am}$ in Fine and Coarse Fractions in

Surface (0-2.5 cm) Sections of Sediment Samples Collected from Bikini

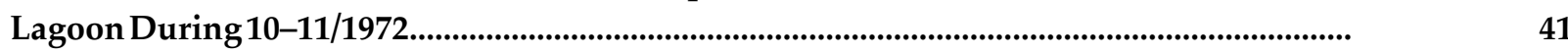

Appendix F: Concentration of ${ }^{241} \mathrm{Am}$ in Fractions from Core Sections of

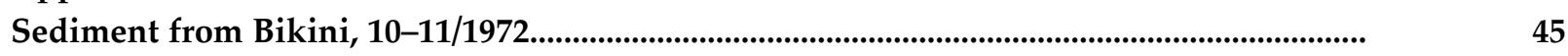

Appendix G: Concentration of ${ }^{241} \mathrm{Am}$ and ${ }^{241} \mathrm{Am} /{ }^{239+240} \mathrm{PuConcentration}$

Ratios in Fine and Coarse Fractions from Surface $(0-2 \mathrm{~cm})$ Sections of

Sediment Samples Collected from Bikini Lagoon During 4-6/1979.................................................. 51

Appendix H: Concentration of ${ }^{241} \mathrm{Am}$ in Fine and Coarse Fractions from

Surface $(0-4 \mathrm{~cm})$ Sections of Sediment Samples Collected from Bikini

Lagoon During 4-6/1979 and Ratio of Inventory in 0-4 cm Section to

Inventory in 0-2 cm Section. 


\section{List of Figures}

Figure 1. Stations locations during the 1972 and 1979 sediment collection

programs

Figure 2. Isoconcentration plot of activity for ${ }^{241} \mathrm{Am}_{\left(\mathrm{Bqkg}^{-1}\right)}$ in the fine components $(<0.5 \mathrm{~mm})$ in surface $(0-2 \mathrm{~cm}$ depth) sediments from 1979 .

Figure 3. Isoconcentration plot of activity for ${ }^{241} \mathrm{Am}_{\left(\mathrm{Bqkg}^{-1}\right)}$ in the coarse components $(>0.5 \mathrm{~mm})$ in surface (0-2 cm depth) sediments from 1979.

Figure 4. Coarse to fine activity ratios for ${ }^{241} \mathrm{Am}$ at lagoon stations sampled in 1979 .

Figure 5. Isoconcentration plot of the inventory for ${ }^{241} \mathrm{Am}\left(\mathrm{kBqm}^{-2}\right)$ in the total sample (fine + coarse) of surface (0-2 cm depth) sediments from 1979.

Figure 6. Isoconcentration plot of the inventory for ${ }^{241} \mathrm{Am}\left(\mathrm{kBqm}^{-2}\right)$ in the total sample (fine + coarse) of surface (0-4 cm depth) sediments from 1979 .

Figure 7. Concentration ratio of ${ }^{241} \mathrm{Am}$ to ${ }^{239+240} \mathrm{Pu}$ in surface sediments from selected stations in lagoon during 1979.

\section{List of Tables}

Table 1. Inventories of ${ }^{241} \mathrm{Am}$ in sediments from regions of Bikini lagoon based on 1979 and 1972 collections.

Table 2. Comparison of 1972 decay-corrected and 1979 measured mean inventories for ${ }^{241} \mathrm{Am}$ and ${ }^{239+240} \mathrm{Pu}$.

Table 3. Core inventories and percent activity of ${ }^{241} \mathrm{Am}$ in the surface $2 \mathrm{~cm}$ of core samples. 


\title{
Sediment Studies at Bikini Atoll Part 2. Inventories of Transuranium Elements in Surface Sediments
}

\author{
Victor E. Noshkin, Rodney J. Eagle, Kai M. Wong, William L. Robison
}

Abstract. This is the second of three reports on Bikini sediment studies, which discusses the concentrations and inventories of ${ }^{241} \mathrm{Am}$ and $239+240 \mathrm{Pu}$ in sediments from the lagoon. Surface sediment samples were collected from 87 locations over the entire lagoon at Bikini Atoll during 1979. The collections were made to map the distribution of longlived radionuclides associated with the bottom material and to show what modifications occurred in the composition of the sediment as a result of the testing program. Present inventories for ${ }^{241} \mathrm{Am}$ and $239+240 \mathrm{Pu}$ in the surface $2 \mathrm{~cm}$ of sediment are estimated to be 14 and $17 \mathrm{TBq}$, respectively. These values are estimated to represent only $14 \%$ of the total inventory in the sediment column. Sediment inventories of $239+240 \mathrm{Pu}$ and ${ }^{241} \mathrm{Am}$ are changing only slowly with time through chemicalphysical processes that continuously mobilize small amounts of the transuranics to the water column. The lowest concentrations and inventories are associated with deposits lagoonward of the eastern reef.

\section{Introduction}

Bikini Atoll, located at about $11^{\circ} 36^{\prime} \mathrm{N}$, $165^{\circ} 22^{\prime} \mathrm{E}$, was one of two sites in the northern Marshall Islands used by the United States between 1946 and 1958 to test nuclear devices. Most of the 23 tests conducted at the atoll were detonated on barges anchored in the lagoon or on the reef. Two tests were airburst detonations, two were explosions under water, and three were ground surface explosions. The locations of the test sites within the atoll are described in Part 1 of this series of reports (Noshkin et al., 1997a). Each test produced some quantity of radioactive fission products, particle-induced radionuclides, or unspent nuclear fuel that became associated with the material incorporated in the fireball from the explosions. Some of this material was deposited locally on islands and in the lagoon. The material deposited over the lagoon eventually settled to the surface of the bottom sediments. Today, only the longer-lived radionuclides are present and associated with environmental components of the Atoll. In the marine environment, these radionuclides are transferred among the sediments and to the water and the biota. Lagoon bottom and surface currents redistribute some material to different regions within the lagoon, and some quantities are transported with surface currents out of the lagoon into the north equatorial Pacific Ocean.

Prior to 1972, little information was available on the inventories or spatial distribution of radionuclides associated with the lagoon sediments. Only five early publications (Lynch et al., 1975; Held, 1971; Beasley and Held, 1971; Welander, et al., 1967; Schell and Yang, 1973) reported measuring specific radionuclides in a few sediment samples collected during 1964 and 1969 from craters and two mid-lagoon locations.

During October and November 1972, personnel from the Puerto Rico Nuclear Center (PRNC), the Laboratory of Radiation Ecology (LRE) at the University of Washington, and Lawrence Livermore National Laboratory (LLNL) participated in a sampling program of the marine environment of Bikini Lagoon. The program was conducted aboard the R.V. Palumbo from PRNC. The purpose of the study was to evaluate the distribution and concentration of the transuranium radionuclides in different components of the marine environment. Included among the collected samples were surface sediments $(2.5 \mathrm{~cm}$ in depth) from 23 widely spaced stations and sediment cores from 9 locations. Additional sediment samples were obtained from within three nuclear craters. These samples provided data to make the first estimate on the concentrations of transuranics and their distribution in the bottom sediments of the 
lagoon. The concentrations of the radionuclides in these samples have since been discussed in several publications (Marshall and Schell, 1974; Mo and Lowman, 1975; Nevissi and Schell, 1975; Noshkin et al., 1975; Schell and Watters, 1975; Schell et al., 1978; Noshkin and Wong, 1980; Schell et al., 1980; Noshkin et al., 1981; Schell, 1987).

Surface sediments were again sampled at 87 locations during 1979. The purpose of the collection was to better map the distribution of the transuranics and other long-lived radionuclides in the bottom surface sediments, to compare the concentrations with the 1972 results, and to assess any modification in specific sedimentary components that resulted from the testing program.

During the late 1970s and early 1980s, sediment studies were assigned a low priority in the marine radiological programs conducted at the Marshall Island Atolls. Analytical efforts were focused on studies that complemented cleanup at Enewetak Atoll, a large radiological survey of several other Northern Marshall Island Atolls, and resettlement at Bikini Atoll. As a result, the sediment data were set aside for assessment at a later date. Support for the marine studies in the Marshall Islands ended in 1984. Therefore, the sediment data from the 1979 program remained unpublished. There is now a need for this information because plans for resettlement at Bikini Atoll call for obtaining lagoon sediments to build causeways and to replace some contaminated soils on specific islands. A better knowledge of the radionuclide activity levels and sediment composition will aid in identifying preferred regions to dredge in the lagoon. Present support and facilities at the Atoll are not adequate to resample the entire lagoon bottom for new surface sediment samples. Therefore, the earlier results are now made available in a series of reports to address the original objectives and provide data for engineering considerations.

The first report (Noshkin et al. 1997a) of this three-part series addresses the distribution of the fine and coarse sedimentary components in the bottom surface sediments. This second report presents data related to the concentrations of ${ }^{241} \mathrm{Am}$ and ${ }^{239+240} \mathrm{Pu}$ radionuclides in the sediment samples. The third report (Noshkin et al. 1997b) in this series will review and discuss the concentrations of other longer-lived radionuclides measured in these bottom surface sediment samples.

\section{Collection and Processing}

Shipboard procedures used for the collection of sediment samples during 1979 are described in Part 1 of this series (Noshkin et al., 1997a). Similar techniques were used in 1972 aboard the RV Palumbo. Sampling locations during the 1972 and 1979 programs are shown in Figure 1.

All samples were placed in plastic bags, frozen, and returned to the laboratories for processing and analysis. At LLNL, the wet weights of the 1972 and 1979 collections were determined. Most of the composite samples were then sieved through a $0.5-\mathrm{mm}$ screen to separate the less than $0.5-\mathrm{mm}$ fraction from the coarse components. Frozen core samples were sectioned into different depth increments before processing. Some sections of the cores were also sieved to separate the fine and coarse fraction. Other sections of cores were processed without separation. Each fraction was dried and weighed. When applicable, the fraction of fine material in the total sample was determined. The amount of Halimeda remains, shell fragments, and foraminifera in the coarse fraction were estimated in the 1979 samples. Both the fine and coarse fractions were ball milled and transferred to containers for analysis by gamma spectrometry using several $\mathrm{Ge}(\mathrm{Li})$ detection systems.

Counting times were usually $1000 \mathrm{~min}$ or longer for each sample. A general-purpose computer program was used for the data reduction of all gamma-ray spectra. A brief description of the gamma-ray program and an account of our quality assurance effort are given in Noshkin, et al. (1988). All radionuclide data were corrected to date of collection. The manmade gamma-emitting radionuclides identified and above detection limits in most 1972 and 1979 fine and coarse components included ${ }^{241} \mathrm{Am}$, ${ }^{155} \mathrm{Eu},{ }^{60} \mathrm{Co},{ }^{207} \mathrm{Bi}$, and ${ }^{137} \mathrm{Cs}$. The radionuclides,

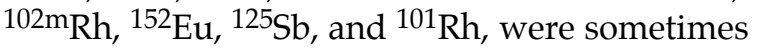
found in concentrations above detection limits in samples collected primarily near test site locations. The third report of this series (Noshkin et al., 1997b) is a summary of the 


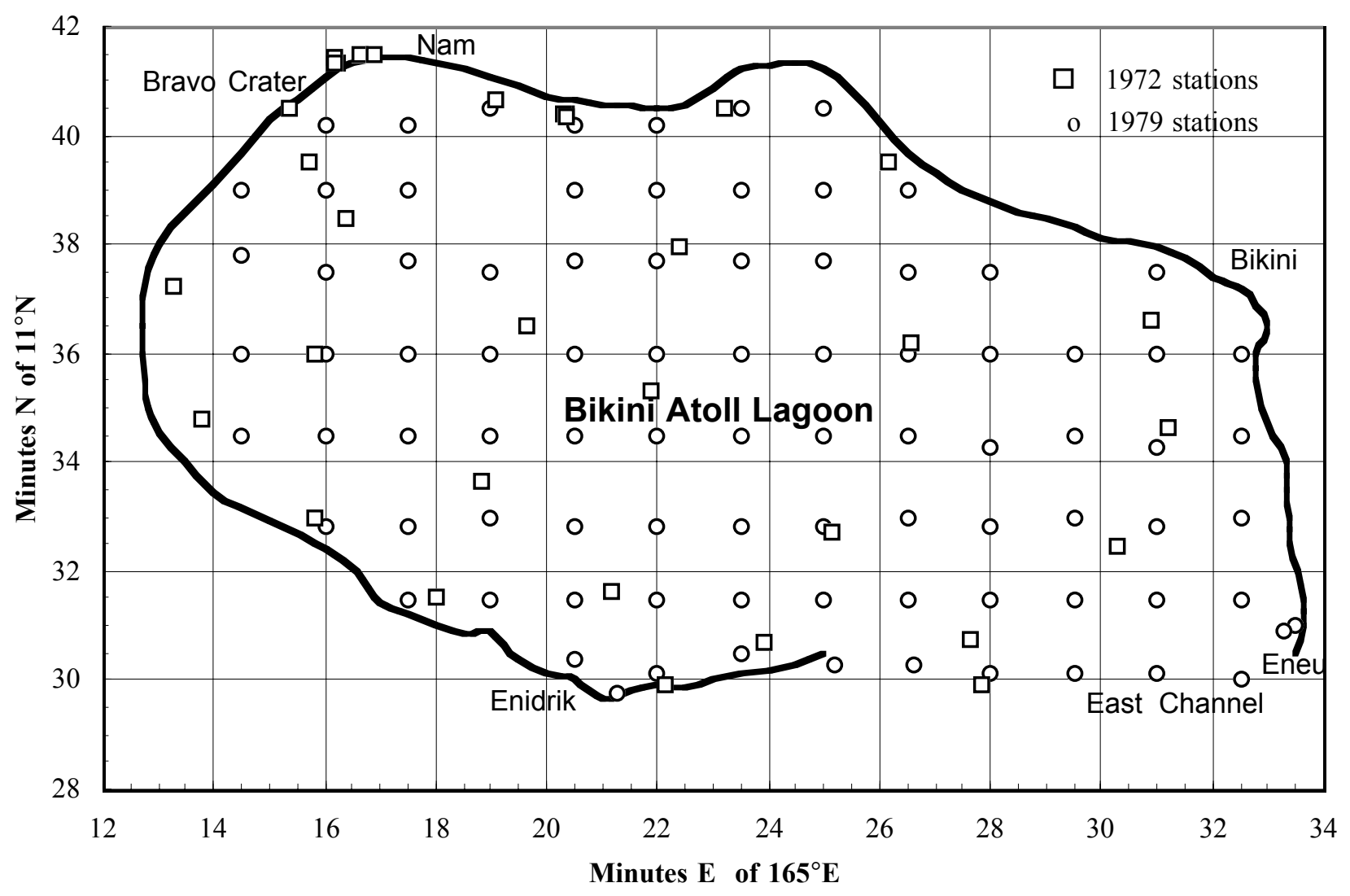

Figure 1. Station locations during the 1972 and 1979 sediment collection programs. 
concentrations and distributions of ${ }^{155} \mathrm{Eu},{ }^{60} \mathrm{Co}$, ${ }^{207} \mathrm{Bi}$, and ${ }^{137} \mathrm{Cs}$ in the sediments from Bikini lagoon.

Chemical separations, following the methodology described in Wong et al. (1994), were used to isolate and determine the concentrations of ${ }^{239+240} \mathrm{Pu}$ and the ${ }^{241} \mathrm{Am}$ to ${ }^{239+240} \mathrm{Pu}$ concentration ratios in a selected number of the 1979 samples.

\section{Results}

Sample data and radiological results for ${ }^{241} \mathrm{Am}$ and ${ }^{239+240} \mathrm{Pu}$ are provided in the appendices. Appendix A describes the surface sediments collected in 1972. Appendix B describes the core samples collected in 1972. Appendix $C$ describes the $0-2 \mathrm{~cm}$ deep surface sediment samples collected in 1979. Appendix D contains information on the $0-4 \mathrm{~cm}$ deep surface sediment samples collected in 1979. Appendix E contains data on concentrations and inventories of ${ }^{241} \mathrm{Am}$ in the fine and coarse fraction and total sample of surface sediment collected in 1972. Appendix F contains data on concentrations and inventories of ${ }^{241} \mathrm{Am}$ in sections of core samples collection in 1972. Appendix $\mathrm{G}$ contains concentrations and inventories of ${ }^{241} \mathrm{Am}$ in the surface $0-2 \mathrm{~cm}$ section of surface sediment and the ${ }^{241} \mathrm{Am}:{ }^{239+240} \mathrm{Pu}$ ratios in selected samples collected in 1979. Appendix H contains concentrations and inventories of ${ }^{241} \mathrm{Am}$ in the 0-4 cm section of surface sediment collected in 1979.

\section{Discussion}

\section{Concentrations of ${ }^{241} \mathrm{Am}$ in Surface Sediments}

The radiological data in the appendices for ${ }^{241} \mathrm{Am}$ are expressed in activity units $(\mathrm{Bq})$ per unit dry weight $(\mathrm{kg})$ and as activity $(\mathrm{kBq})$ per unit area $\left(\mathrm{m}^{2}\right)$ associated with the fine and coarse fractions and in the reconstructed whole sample. Each unit is useful to describe certain features of the analytical data.

Concentration data for ${ }^{241} \mathrm{Am}$ in the fine and coarse fractions from the $0-2 \mathrm{~cm}$ surface sections (from Appendix $G$ ) are plotted on a lagoon chart at the stations sampled. Isoconcentrations lines were constructed to define regions of the bottom sediment with similar concentrations. The resulting distributions of ${ }^{241} \mathrm{Am}$ associated with the fine $(<0.5-\mathrm{mm})$ and coarse $(>0.5-\mathrm{mm})$ bottom material are shown in Figures 2 and 3. The radionuclide is everywhere associated with the fine and coarse sedimentary components. The concentrations in both fractions from the regions outside the $100 \mathrm{Bqkg}^{-1}$ contours ranged from 10 to $99 \mathrm{Bqkg}^{-1}$. The highest concentration are associated with the sediments from the northwestern quadrant of the lagoon, adjacent to the locations of the larger explosions (see Part 1 for test locations in the atoll). Surface concentrations in both fractions decrease from the north to the south and from the west to the east. The highest concentration in the samples collected was associated with the coarse fraction from the lagoon near Bravo crater. Figure 4 shows the ratio of activity for ${ }^{241} \mathrm{Am}$ in the coarse to fine fractions. There are several small areas in the western and central lagoon and larger regions lagoonward of the eastern reef and near the east channel where the activity in the coarse fraction is equivalent to or greater than the activity associated with the fine material. Elsewhere, most of the activity is associated with the fine sedimentary material. In the region west of $165^{\circ} 24^{\prime} \mathrm{E}$ and north of $11^{\circ} 36^{\prime} \mathrm{N}$, the average activity ratio, at the stations where the ratios are $<1$, is $0.4 \pm 0.2$. In the remainder of the lagoon, at stations where the activity ratios are $<1$, the mean activity ratio is $0.7 \pm 0.2$.

\section{${ }^{241} \mathrm{Am}$ and ${ }^{239+240} \mathrm{Pu}$ Inventories in Surface Sediment}

The primary purpose of this report is to define the distribution and estimate the inventory of radionuclides that remain associated with the lagoon sediments. Therefore, the activity per unit area better describes distributions and is the more useful unit for making relative comparisons of areal and temporal changes in inventories.

Inventories of ${ }^{241} \mathrm{Am}$ in the bottom sediment to depths of 2 and $4 \mathrm{~cm}$ from the data in Appendices $\mathrm{G}$ and $\mathrm{H}$ were also plotted on lagoon charts. Isoconcentration lines were constructed to distinguish regions of the bottom surface sediment with comparable inventories. Figures 5 and 6 show the $\mathrm{kBqm}^{-2}$ of ${ }^{241} \mathrm{Am}$ in the bottom sediment to depths of 2 and $4 \mathrm{~cm}$, respectively. Ordered inventory values in the 


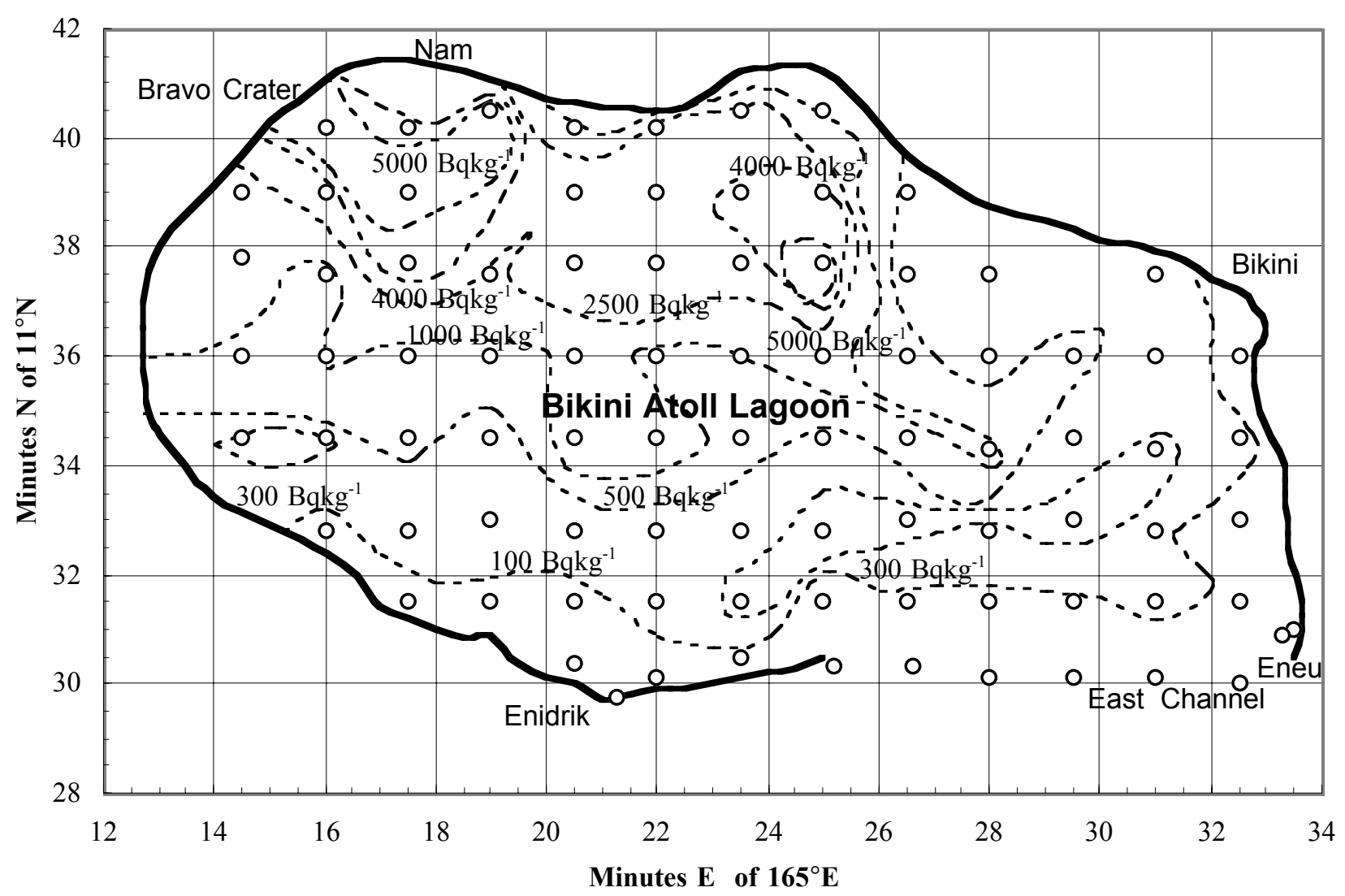

Figure 2. Isoconcentration plot of activity for ${ }^{241} \mathrm{Am}^{\left(\mathrm{Bqkg}^{-1}\right)}$ in the fine components $(<0.5 \mathrm{~mm})$ in surface (0-2 cm depth) sediments from 1979. 


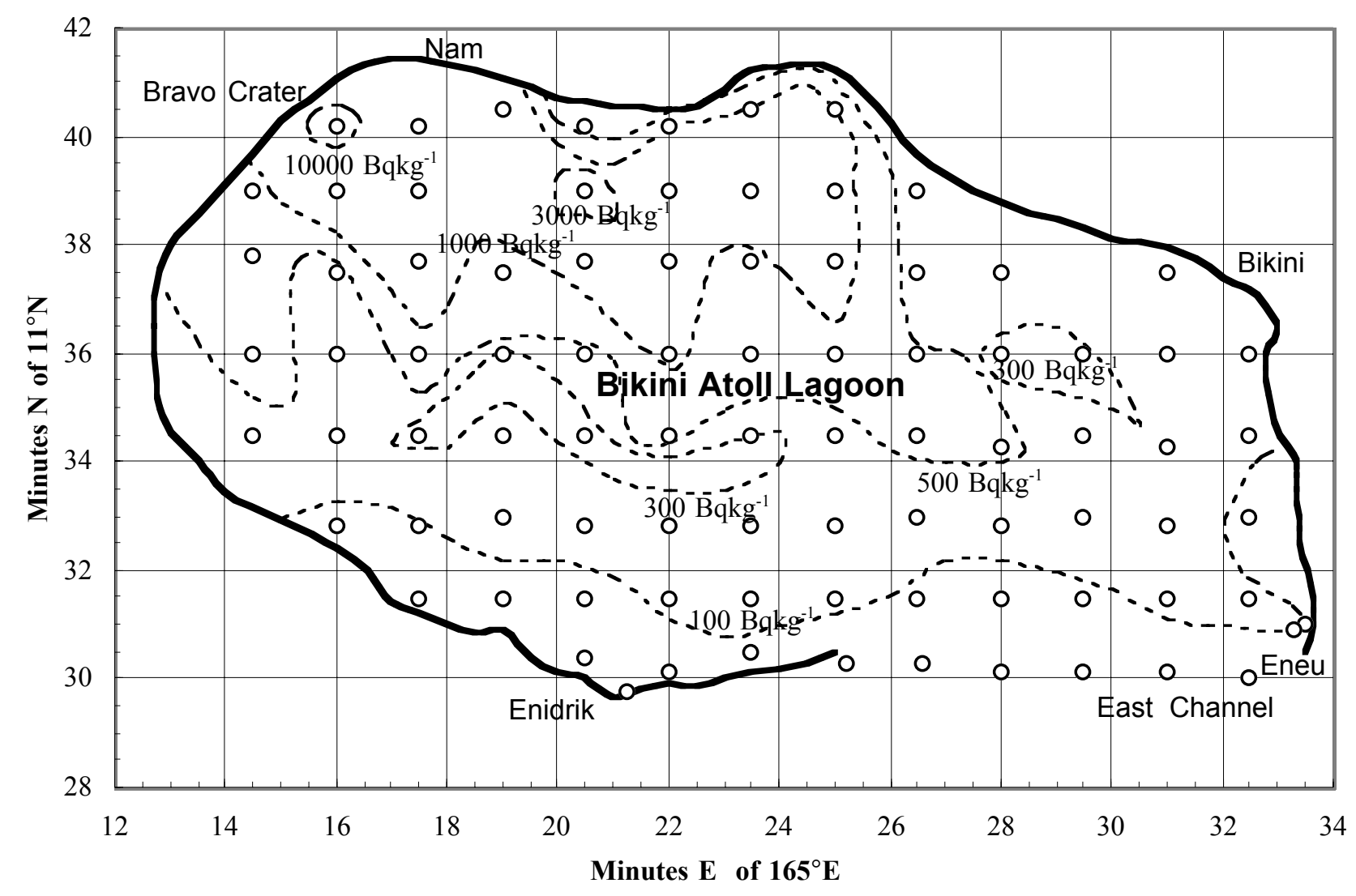

Figure 3. Isoconcentration plot of activity for ${ }^{241} \mathrm{Am}^{\left(\mathrm{Bqkg}^{-1}\right)}$ in the coarse components $(>0.5 \mathrm{~mm})$ in surface (0-2 cm depth) sediments from 1979. 


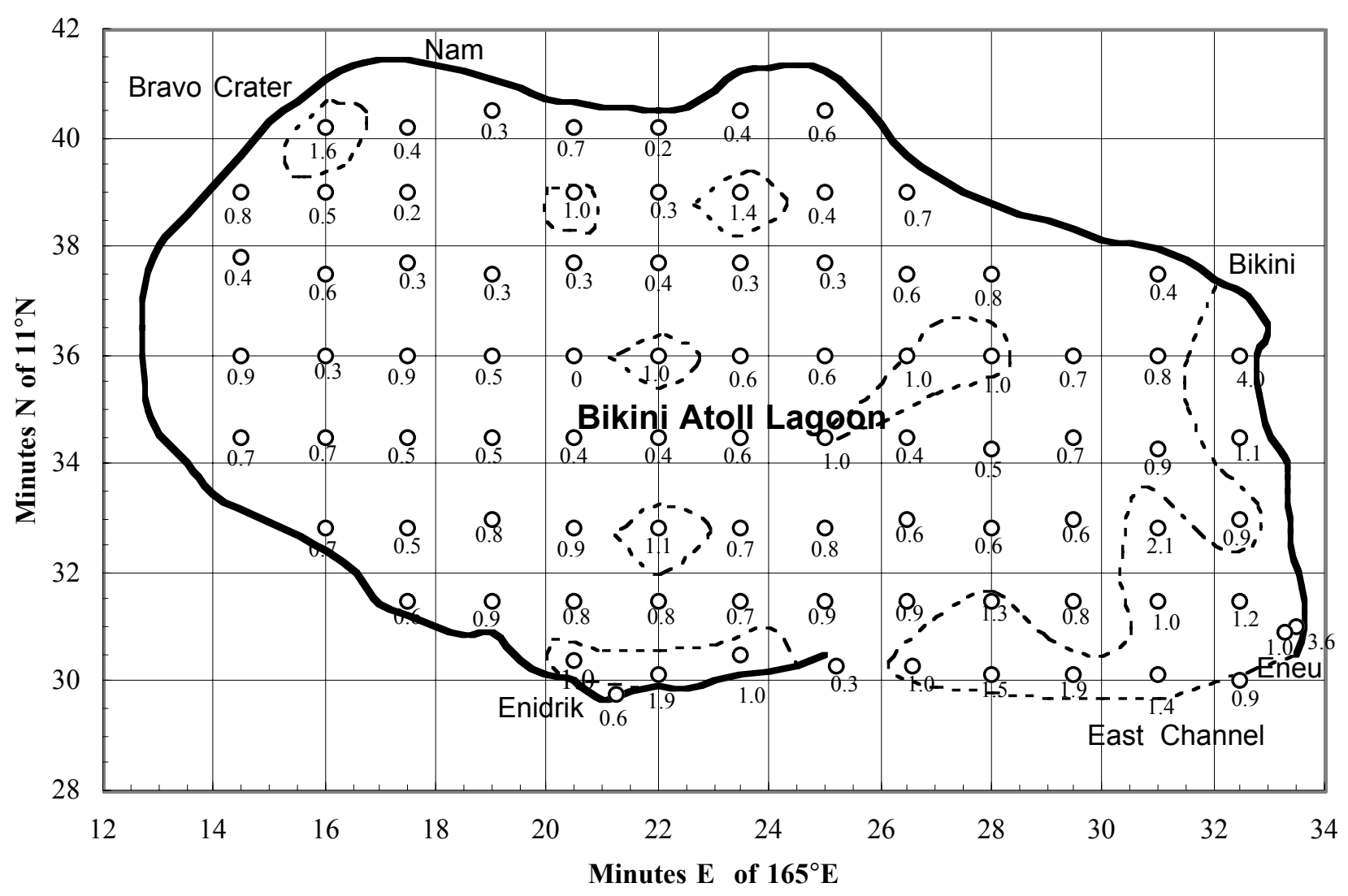

Figure 4. Coarse-to-fine activity ratios for ${ }^{241} \mathrm{Am}$ at lagoon stations sampled in 1979. 


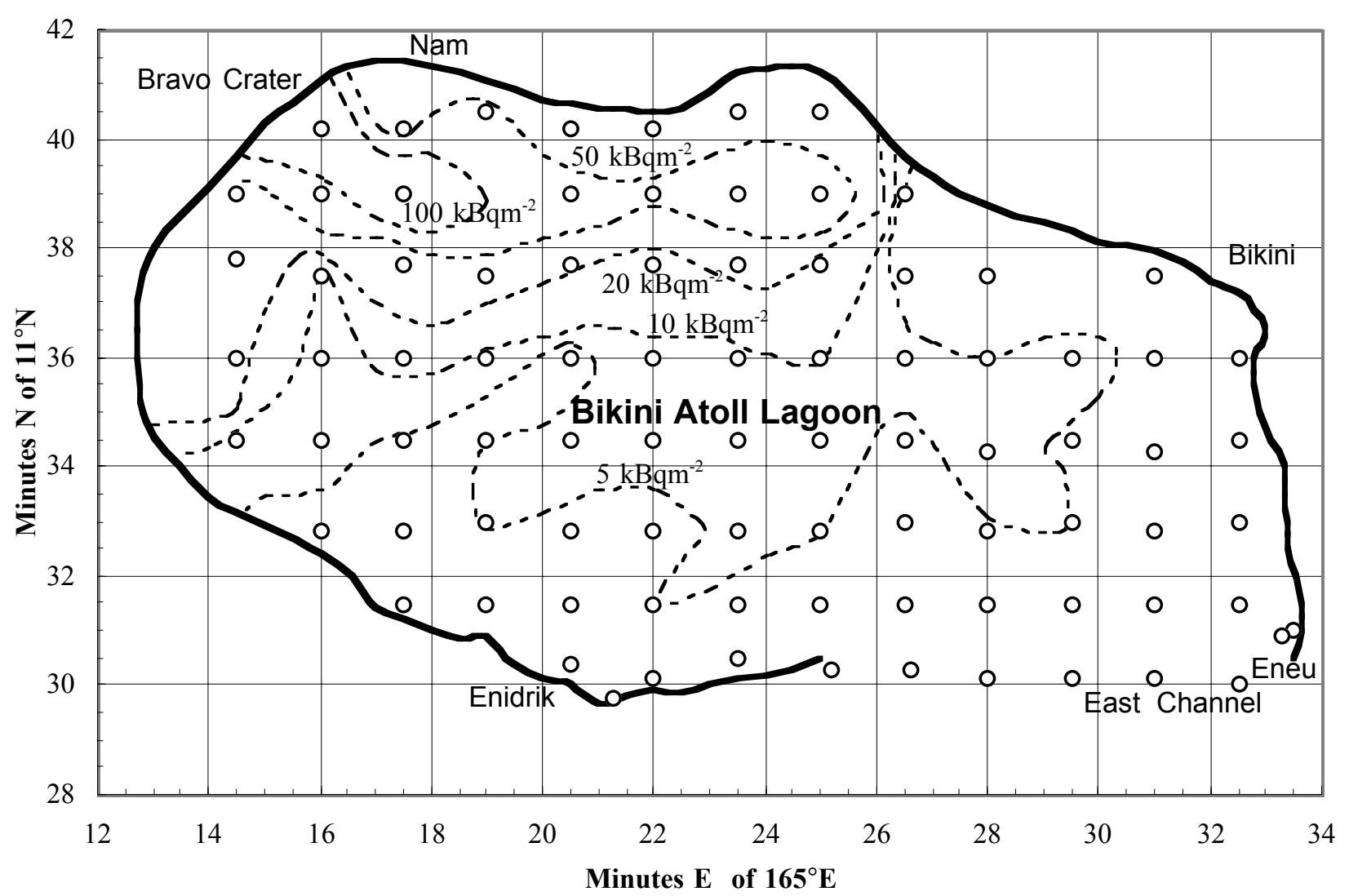

Figure 5. Isoconcentration plot of the inventory for ${ }^{241} \mathrm{Am}\left(\mathrm{kBqm}^{-2}\right)$ in the total sample (fine + coarse) in surface (0-2 cm depth) sediments from 1979. 


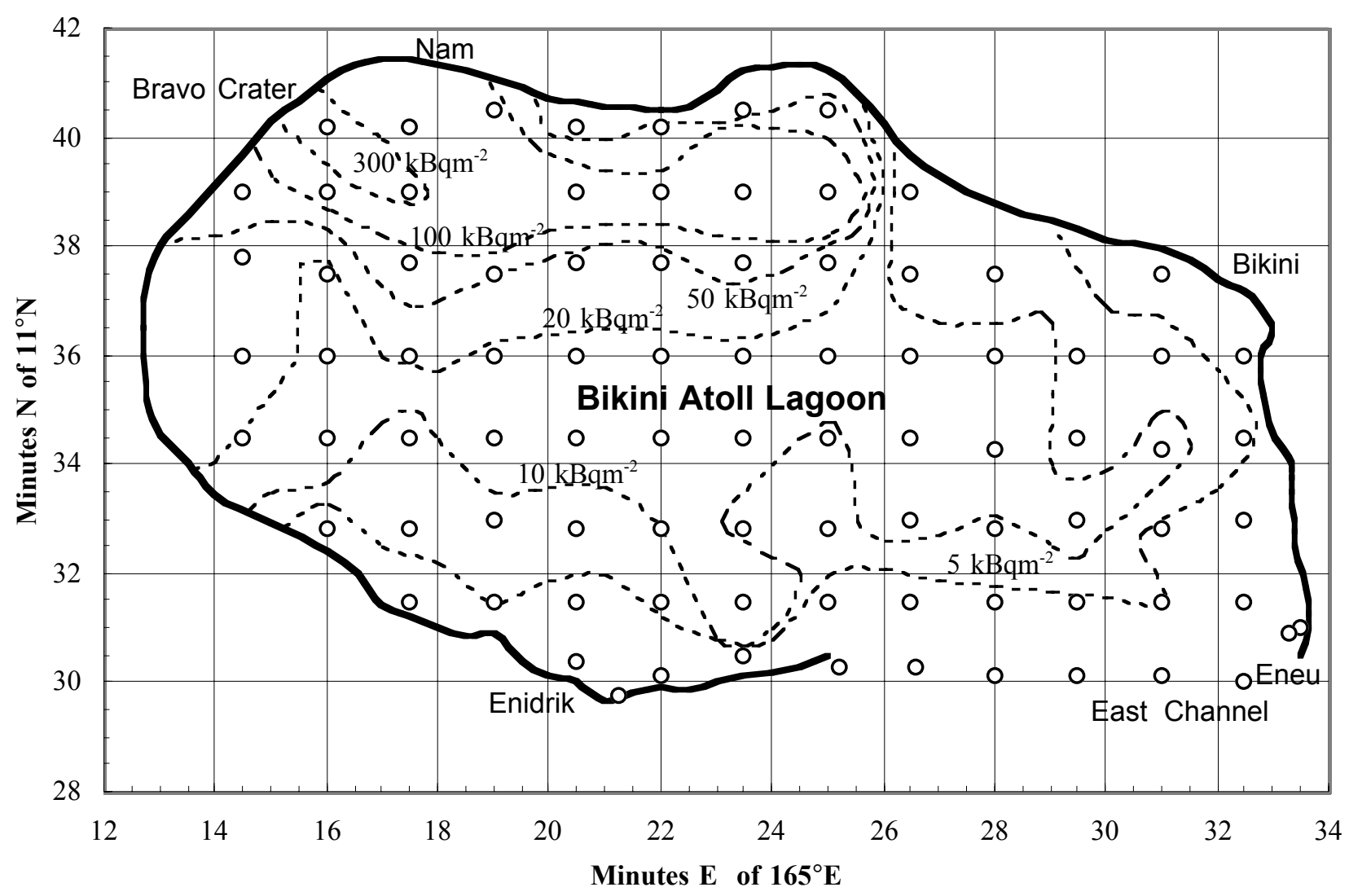

Figure 6. Isoconcentration plot of the inventory for ${ }^{241} \mathrm{Am}\left(\mathrm{kBqm}^{-2}\right)$ in the total sample (fine + coarse) of surface (0-4 cm depth) sediments from 1979. 
enclosed regions plot reasonably well as a straight line on a log normal probability plot. Therefore, throughout this report, mean values for inventories and the associated variances are computed assuming all data are log normally distributed.

The area between the contour intervals is determined along with the $\ln$ normal mean inventory $\left(\mathrm{kBq} \mathrm{m}^{-2}\right)$ from the data associated with each station included in the respective region. Multiplying the area by the mean inventory provides an estimate of the total amount of ${ }^{241} \mathrm{Am}$ associated with the sediment within a region. Summing these quantities produces an estimate of the total amount of ${ }^{241} \mathrm{Am}$ associated with surface $2-$ and $4-\mathrm{cm}$ layer of sediment over the entire lagoon. A comparable procedure is used with the smaller number of 1972 data points [and some supplemental ${ }^{241} \mathrm{Am}$ sediment data from Schell et al. (1980)] to arrive at estimates of ${ }^{241} \mathrm{Am}$ inventories within specific intervals.

Respective areas and mean inventories for the 1972 and 1979 data sets are shown in Table 1.

In Table 2, the 1972 mean lagoon inventory, determined to a depth of $2.5 \mathrm{~cm}$, is corrected to a depth of $2 \mathrm{~cm}$. To do so, it is assumed the surface sediments are well mixed over a few centimeters and that the inventory increases linearly with depth. This assumption is supported by comparing the activity of ${ }^{241} \mathrm{Am}$ in the $0-4$ and $0-2$ depth increments from the same stations in the 1979 collections. From Appendix $\mathrm{H}$, the mean activity ratio in 70 comparable samples is $1.2 \pm 0.4$, and the average inventory ratio is $2.2 \pm 1.0$. This comparison indicates that the radionuclide is reasonably well mixed over at least the first 4 $\mathrm{cm}$ of surface sediment. Therefore, the inventory of ${ }^{241} \mathrm{Am}$ to a depth of $2.0 \mathrm{~cm}$ in 1972 is estimated to be 0.8 times the value measured at $2.5 \mathrm{~cm}$. In addition, the inventory to $4.0 \mathrm{~cm}$ in 1979 is multiplied by 0.5 to provide another comparative value to a depth of $2 \mathrm{~cm}$. This value is also shown in Table 2.

The 1972 value for ${ }^{241} \mathrm{Am}$ is decay corrected to 6/1979 for comparison with the total inventory determined in 1979. Two assumptions are necessary to make this correction. It is assumed that loss (gain) from the sediment surface during the intervening 6.58 years is from radioactive decay (growth). Mobilization from the sediments accounts for some additional loss, but the amount of ${ }^{241} \mathrm{Am}$ and ${ }^{239+240} \mathrm{Pu}$ found at any time in the lagoon water represents a very small fraction $(<0.1 \%)$ of the sediment inventory (Noshkin, 1980; Noshkin and Wong, 1980). An additional small loss is due to decay, but the largest change in the inventory of ${ }^{241} \mathrm{Am}$ is from ingrowth due to ${ }^{241} \mathrm{Pu}$ decay. Values for ${ }^{241} \mathrm{Am}$ and ${ }^{241} \mathrm{Pu}$ were taken from the 1972 growth increment in a sample of living coral from Bikini lagoon (Noshkin et al., 1975). The relative amounts of the radionuclides in this one sample were assumed to be representative of the relative amounts in the entire lagoon. The appropriate growth-decay equation was used to estimate the change in the level of ${ }^{241}$ Am during 6.58 years.

In 1972 , the inventory for ${ }^{239+240} \mathrm{Pu}$ was estimated from the mean of 20 activity ratios determined for ${ }^{241} \mathrm{Am} /{ }^{239+240} \mathrm{Pu}(0.53 \pm 0.17)$ in surface sediments by Schell, et al., (1980) and the estimated 1972 mean ${ }^{241} \mathrm{Am}$ inventory value in Table 1.

In 1979, the estimated inventory for $239+240 \mathrm{Pu}$ is based on the mean ${ }^{241} \mathrm{Am}$ to ${ }^{239+240} \mathrm{Pu}$ concentration ratio of $0.69 \pm 0.17$ determined in 19 measured ratios shown in Appendix $\mathrm{G}$ and the measured ${ }^{241} \mathrm{Am}$ inventory in Tables 1 and 2. The individual activity ratios at the 19 stations sampled are shown in Figure 7. Somewhat higher ratios are evident in the surface sediment from the NW section of the lagoon. A mean activity ratio of $0.86 \pm 0.09$ is computed from the six samples in the NW section of the lagoon. The samples from the remainder of the lagoon have a mean activity ratio of $0.61 \pm 0.13$. The difference is not considered significant because of the limited amount of available data. Therefore, the mean activity ratio of $0.69 \pm 17$, rather than an assessment of an isoconcentration plot, is used to estimate the ${ }^{239+240} \mathrm{Pu}$ inventory. Mean inventories estimated during 1972 and 1979 are shown in Table 2.

\section{Distribution with Depth in Sediment Column}

The sediments appear well mixed to at least a depth of $4 \mathrm{~cm}$. Table 3 shows the inventories for ${ }^{241} \mathrm{Am}$ in the 1972 core samples to the maximum depth sampled. The values are derived from data in Appendix F. The quantities in the $0-2 \mathrm{~cm}$ surface layer were determined from plots of the incremental 
Table 1. Inventories of ${ }^{241} \mathrm{Am}$ in sediments from regions of Bikini lagoon based on 1979 and 1972 collections.

Area of Bikini lagoon $=629 \mathrm{~km}^{2}$.

${ }^{241}$ Am inventory based on 1979 collections

\begin{tabular}{|c|c|c|c|}
\hline $\begin{array}{c}\text { Inventory } \\
\text { interval }\left(\mathrm{kBqm}^{-2}\right)\end{array}$ & $\begin{array}{c}\text { In normal mean } \\
\left(\mathrm{kBqm}^{-2}\right)\end{array}$ & $\begin{array}{c}\text { Area of interval } \\
\left(\mathrm{km}^{2}\right)\end{array}$ & $\begin{array}{l}\text { TBq in interval } \\
\text { to depth of } 2.0 \mathrm{~cm}\end{array}$ \\
\hline $0-5$ & $2.6 \pm 1.8$ & 277 & $0.7 \pm 0.5$ \\
\hline $5-10$ & $7.3 \pm 1.7$ & 148 & $1.1 \pm 0.3$ \\
\hline $10-20$ & $13.5 \pm 2.6$ & 44 & $0.6 \pm 0.1$ \\
\hline $20-50$ & $32.1 \pm 9.9$ & 84 & $2.7 \pm 0.8$ \\
\hline 50-100 & $74.1 \pm 17.6$ & 54 & $4.0 \pm 1.0$ \\
\hline \multirow[t]{2}{*}{$>100$} & $177 \pm 16$ & 22 & $\underline{3.9 \pm 0.4}$ \\
\hline & & Lagoon total & $13.0 \pm 1.4$ \\
\hline
\end{tabular}

${ }^{241}$ Am inventory based on 1979 collections

\begin{tabular}{|c|c|c|c|}
\hline $\begin{array}{c}\text { Inventory } \\
\text { interval }\left(\mathrm{kBqm}^{-2}\right)\end{array}$ & $\begin{array}{c}\text { In normal mean } \\
\left(\mathrm{kBqm}^{-2}\right)\end{array}$ & $\begin{array}{c}\text { Area of interval } \\
\left(\mathrm{km}^{2}\right)\end{array}$ & $\begin{array}{l}\text { TBq in interval } \\
\text { to depth of } 4.0 \mathrm{~cm}\end{array}$ \\
\hline $0-5$ & $2.7 \pm 1.6$ & 133 & $0.4 \pm 0.2$ \\
\hline $5-10$ & $7.6 \pm 1.3$ & 129 & $1.0 \pm 0.2$ \\
\hline $10-20$ & $14.5 \pm 2.8$ & 166 & $2.4 \pm 0.5$ \\
\hline $20-50$ & $30.9 \pm 10.8$ & 101 & $3.1 \pm 1.1$ \\
\hline $50-100$ & $71.9 \pm 19.4$ & 48 & $3.5 \pm 0.9$ \\
\hline $100-250$ & $140.5 \pm 15.3$ & 39 & $5.5 \pm 0.6$ \\
\hline \multirow[t]{3}{*}{$>250$} & 397 & 14 & $\underline{5.6 \pm 0.6}$ \\
\hline & & Lagoon total & $21.4 \pm 1.7$ \\
\hline & \multicolumn{3}{|c|}{${ }^{241}$ Am inventory based on 1972 collections } \\
\hline $\begin{array}{c}\text { Inventory } \\
\text { interval }\left(\mathrm{kBqm}^{-2}\right)\end{array}$ & $\begin{array}{c}\text { In normal mean } \\
\left(\mathrm{kBqm}^{-2}\right)\end{array}$ & $\begin{array}{c}\text { Area of interval } \\
\left(\mathbf{k m}^{2}\right)\end{array}$ & $\begin{array}{l}\text { TBq in interval } \\
\text { to depth of } 2.5 \mathrm{~cm}\end{array}$ \\
\hline $0-5$ & $2.7 \pm 3.8$ & 275 & $0.8 \pm 1.0$ \\
\hline $5-10$ & $6.9 \pm 1.7$ & 33 & $0.9 \pm 0.2$ \\
\hline $10-20$ & $16.0 \pm 1.9$ & 71 & $1.1 \pm 0.1$ \\
\hline $20-50$ & $30.8 \pm 5.6$ & 102 & $3.2 \pm 0.6$ \\
\hline \multirow[t]{2}{*}{$>50$} & $74.6 \pm 7.0$ & 49 & $\underline{3.7 \pm 0.3}$ \\
\hline & & Lagoon total & $9.6 \pm 1.3$ \\
\hline
\end{tabular}


Table 2. Comparison of 1972 decay-corrected and 1979 mean inventories for ${ }^{241} \mathrm{Am}$ and ${ }^{239+240} \mathrm{Pu}$.

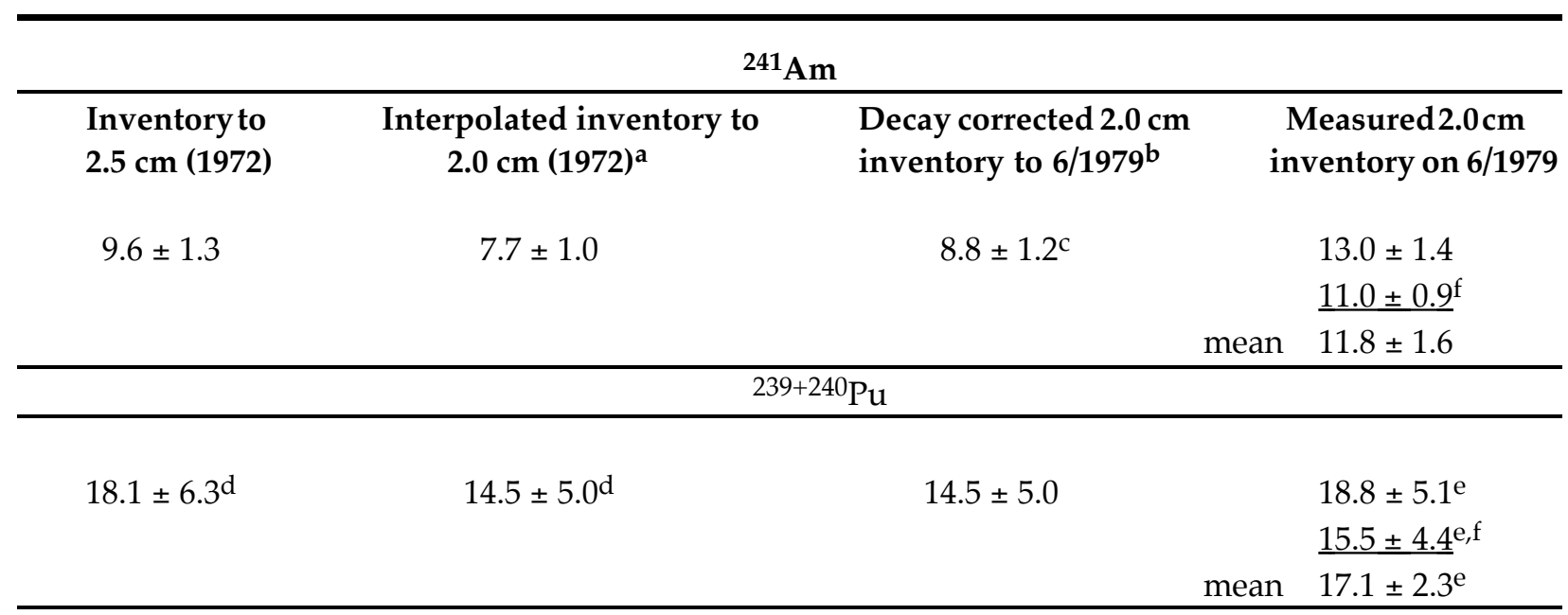

aAssumes inventory over first $2.5 \mathrm{~cm}$ is well mixed. Inventory to $2.0 \mathrm{~cm}$ is 0.8 times the value to $2.5 \mathrm{~cm}$. (see text).

${ }^{b}$ Assumes loss from sediment surface during the intervening years is only from radioactive decay (growth).

cBased on ingrowth from ${ }^{241} \mathrm{Pu}$ during 6.58 years. Values for ${ }^{241} \mathrm{Am}$ and ${ }^{241} \mathrm{Pu}$ from 1972 growth increment in sample of living coral from Bikini (Noshkin et al., 1975).

${ }^{d}$ Based on mean ${ }^{241} \mathrm{Am}$ to ${ }^{239+240} \mathrm{Pu}$ concentration ratio of $0.53 \pm 0.17$ determined in 20 surface sediment samples in 1972 (Schell et al., 1980) and ${ }^{241}$ Am inventory value listed above (1972).

eBased on mean ${ }^{241} \mathrm{Am}$ to ${ }^{239+240} \mathrm{Pu}$ concentration ratio of $0.69 \pm 0.17$ measured in 19 surface sediment samples in 1979 (Appendix G) and ${ }^{241}$ Am inventory values listed above (1979).

${ }_{\mathrm{f}}$ Assumes inventory over first $4 \mathrm{~cm}$ is well mixed. Inventory to $2.0 \mathrm{~cm}$ is 0.5 times the value to $4.0 \mathrm{~cm}$.

Table 3. Core inventories and percent activity of ${ }^{241} \mathrm{Am}$ in the surface $2 \mathrm{~cm}$ of core samples.

\begin{tabular}{cccc}
\hline Core ID & $\begin{array}{c}\text { Maximum depth } \\
\text { sampled (cm) }\end{array}$ & $\begin{array}{c}\text { Total kBqm } \\
\text { maximum depth }\end{array}$ & $\begin{array}{c}\text { Percentin } \\
\text { 0-2 cm section }\end{array}$ \\
\hline All Samples (1979) & 4 & 21 & 45 \\
B4 & 7 & 6 & 24 \\
B18 & 10.5 & 374 & 16 \\
B15 & 15 & 10 & 14 \\
B16 & 15 & 11 & 15 \\
B20 & 15 & 214 & 22 \\
B25 & 8 & 100 & 9 \\
B3 & 35 & 66 & 12 \\
\hline
\end{tabular}




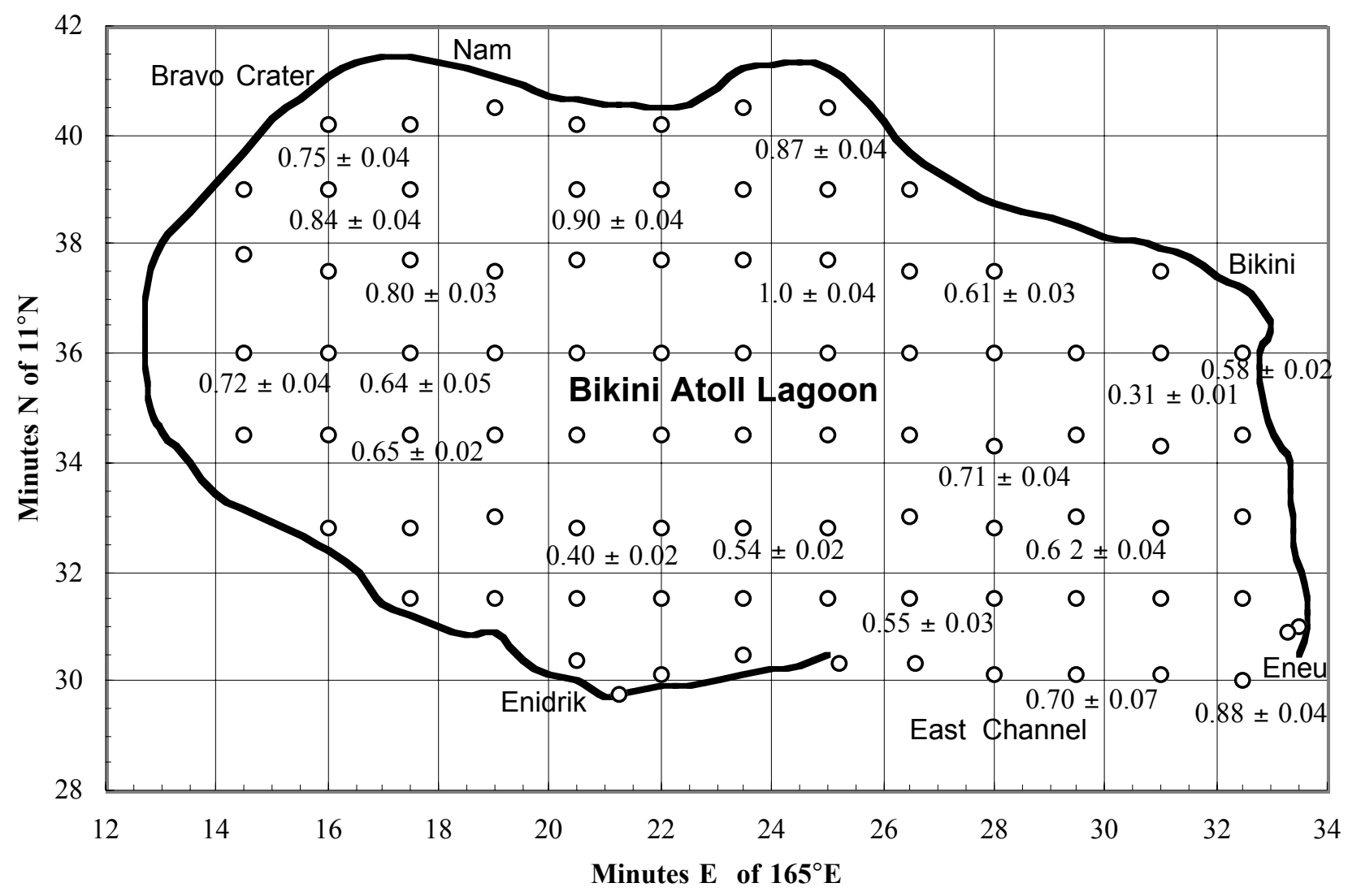

Figure 7. Concentration ratio of ${ }^{241} \mathrm{Am}$ to ${ }^{239+240} \mathrm{Pu}$ in surface sediments from selected stations in lagoon during 1979. 
concentration data with depth. The percent of the inventory in the $0-2 \mathrm{~cm}$ layer is compared to the total at the maximum depth sampled. There appear to be two zones in the sediment column. To about $9 \mathrm{~cm}$ in the sediment column, the inventory increases approximately in a linear fashion. Below about $10 \mathrm{~cm}$, the total inventory changes slowly if at all. The inventory in the $0-2 \mathrm{~cm}$ layer compared to the total inventory (to depths of $10-35 \mathrm{~cm}$ ) in the core is about $14 \pm 5 \%$. Assuming this is a representative fraction over the entire lagoon for both ${ }^{241} \mathrm{Am}$ and ${ }^{239+240} \mathrm{Pu}$, then the total inventory to depth in the sediment in 1979 is estimated to be 84 and $122 \mathrm{TBq}$ for ${ }^{241} \mathrm{Am}$ and $239+240 \mathrm{Pu}$, respectively. These values should be viewed as lower limits because radionuclides are evident at greater depths in some cores from Enewetak (Noshkin, 1980; McMurtry, et al., 1985).

\section{Conclusions}

There is reasonable agreement between the estimate of the mean lagoon inventory for ${ }^{241} \mathrm{Am}$ in the $0-2 \mathrm{~cm}$ surface section of sediment based on the samples collected in 1972 and the value estimated from the 1979 collection. Only small quantities of the transuranics are lost by remobilization processes from the sedimentary reservoir to the water column of the lagoon. Surface inventories $(0-2 \mathrm{~cm})$ for ${ }^{241} \mathrm{Am}$ and ${ }^{239+240} \mathrm{Pu}$ are estimated to be approximately 14 and $17 \mathrm{TBq}$, respectively, when decay corrected to $6 / 1996$. The inventories to greater depths are estimated to be about 100 and $120 \mathrm{TBq}$, respectively. These amounts should be considered to be minimum values of the present inventories for these transuranics in the lagoon sediments. The inventory of americium and plutonium in the lagoon surface sediment will only slowly change with time unless the chemical-physical processes that now regulate the release of the isotopes to the water column are changed or altered.

Inventories and concentrations of the transuranics are lowest in surface sediments from the eastern region of the lagoon. This is the portion of the atoll where the main residence islands have been and will be located. Sediments in the region consist mainly of fine material (Noshkin et al., 1997a). Low concentrations of transuranics are found in the sediment lagoonward of the eastern reef. This area would appear to be the preferred region of the lagoon to dredge if low concentrations of transuranics and quantities of fine material are prerequisites for local construction material.

\section{Acknowledgments}

The authors acknowledge the assistance of Mr. K. V. Marsh and Mr. J. Schweiger in collecting lagoon sediment samples.

\section{References}

Beasley, T.M. and E.E. Held (1971), "Silver$108 \mathrm{~m}$ in Biota and Sediments at Bikini and Eniwetok Atolls," Nature 230, 450-451.

Held, E.E (1971), Radiological Resurvey of Animals, Soils and Groundwater at Bikini Atoll, 1969-1970, U. of Washington, Lab. of Radiation Ecology, Seattle, WA, Rept. NVO-269-8 (Rev. 1).

Lynch, O.D.T., T.F. McCraw, V.A. Nelson, and W.E. Moore (1975), Radiological Resurvey of Food, Soil, Air and Groundwater at Bikini Atoll, 1972, U.S. Energy Research Development Administration, Washington, D.C., ERDA-34.

Marshall, R.P. and W.R. Schell (1974), Distribution of Alpha Emitting Radionuclides in Sediments of Bikini Atoll Lagoon, U. of Washington, Lab of Radiation Ecology, Seattle, WA, RLO2225-T18-12.

Mo, T. and F.G Lowman (1975), “Laboratory Experiments On the Transfer of Plutonium from Marine Sediments to Seawater and to Marine Organisms," Ecol. Soc. of America, Radioecol. \& Energy Series, 86-95.

Nevissi, A. and W.R. Schell (1975), "Distribution of Plutonium and Americium in Bikini Atoll Lagoon," Health Phys. 28, 539-547.

Noshkin, V.E. (1980), “Transuranium Radionuclides in Components of the Benthic Environment of Enewetak Atoll," in Transuranic Elements in the Environment, Hanson, W.C., Eds., U.S. Department of Energy, Washington, D.C., DOE/TIC22800 . 
Noshkin, V.E. and K.M. Wong (1980), "Plutonium Mobilization from Sedimentary Sources to Solution in the Marine Environment," Marine Radioecology (Proc. 3rd NEA Seminar Tokyo, 1979), NEA, OECD, Paris, 729.

Noshkin, V.E., K.M. Wong, R.J. Eagle, and C. Gatrousis (1975), "Transuranics and Other Radionuclides in Bikini Lagoon: Concentration data retrieved from aged coral sections," Limno. \& Oceano 20, 729 742.

Noshkin, V.E., K.M. Wong, R.J. Eagle, T.A. Jokela, and J.L. Brunk (1988), Radionuclide Concentrations in Fish and Invertebrates from Bikini Atoll, Lawrence Livermore National Laboratory, Livermore, CA, UCRL-53846.

Noshkin, V.E., R.J. Eagle, K.M. Wong, and T.A. Jokela (1981), “Transuranic Concentrations in Reef and Pelagic Fish from the Marshall Islands," in Impacts of Radionuclide Releases into the Marine Environment, Proc. Symp., Vienna, Austria, 1980, IAEASM-248/146, IAEA, Vienna.

Noshkin, V.E., R.J. Eagle, and W.L. Robison (1997a), Sediment Studies at Bikini Atoll Part 1. Distribution of Fine and Coarse Components in Surface Sediments, Lawrence Livermore National Laboratory, Livermore, CA, UCRL-LR-126641.

Noshkin, V.E., R.J. Eagle, J.L. Brunk, and W.L. Robison (1997b), Sediment Studies at Bikini Atoll Part 3. Inventories of Some Long Lived Gamma Emitting Radionuclides Associated with Lagoon Surface Sediment, Lawrence Livermore National Laboratory, Livermore, CA, (in press).
Schell, W.R. (1987), "Biogeochemical Cycling of Radionuclides in the Reef Ecosystem at Bikini Atoll," in: Proc. of a Seminar on The Cycling of Long-Lived Radionuclides in the Biosphere: Observations and Models, September 1986, Vol. II. Centro de Investigaciones Energeticas, Medioambientales y Tecnologicas, Madrid, Spain.

Schell W.R., and C.I. A. Yang (1973), LongLived Radionuclides Produced at Bikini and Eniwetok Atolls, U. of Washington, Lab of Radiation Biology, Seattle, WA, RLO-2225-T-18-3.

Schell, W.R., and R.L. Watters (1975), "Plutonium in Aqueous Systems," Health Phys. 29, 589-597.

Schell, W.R., F.G. Lowman, and R.P. Marshall (1980), "Geochemistry of Transuranic Elements at Bikini Atoll," in: Transuranic Elements in the Environment, W.C. Hansen, Ed., U.S. Department of Energy, Washington, D.C., DOE/TIC-22800.

Schell, W.R., A. Nevissi, and J.M. Meyers (1978), Biogeochemistry of Transuranic Elements in Bikini Atoll Lagoon, U. of Washington, Lab of Radiation Ecology, Seattle, WA, RLO-2225-T18-22.

Welander, A.D., K. Bonham, R.F. Palumbo, S.E. Gessel, F.G. Jackson, R. McClin, and G.B. Lewis (1967), Bikini-Eniwetok Studies, 1964, Part II. Radiobiological Studies, U. of Washington, Lab of Radiation Biology, Seattle, WA, UWFL-93 part II.

Wong, K.M., T.A. Jokela, and V.E. Noshkin (1994), Radiochemical Procedures for Analysis of Pu, Am, Cs, and Sr in water, Soil, Sediments and Biota Samples, Lawrence Livermore National Laboratory, Livermore, CA, UCRL-ID-116497. 

Appendix A

Description of Bikini Lagoon Surface Sediments (0-2.5 cm) Collected During 10-11/1972 

Appendix A. Description of Bikini lagoon surface sediments $(0-2.5 \mathrm{~cm})$ collected during 10-11/1972.

\begin{tabular}{|c|c|c|c|c|c|c|c|c|}
\hline $\begin{array}{c}\text { Station } \\
\text { No. }\end{array}$ & $\begin{array}{c}\text { MSC } \\
\text { No. }\end{array}$ & $\begin{array}{c}\text { Volume } \\
\text { total } \\
\text { sample } \\
\left(\mathrm{cm}^{3}\right)\end{array}$ & $\begin{array}{l}\text { Dry wt } \\
\quad \text { fine } \\
\text { and coarse } \\
\text { fraction }(g)\end{array}$ & $\begin{array}{c}\text { Total } \\
\text { dry } \\
\text { sample wt } \\
\text { (g) }\end{array}$ & $\begin{array}{c}\text { Fines } \\
\text { (fraction } \\
\text { of total } \\
\text { dry } w t)\end{array}$ & $\begin{array}{c}\text { Minutes } \\
\text { east of } \\
165^{\circ} \mathrm{E} \\
X \text {-coord }\end{array}$ & $\begin{array}{c}\text { Minutes } \\
\text { north of } \\
11^{\circ} \mathrm{N} \\
\text { Y-coord }\end{array}$ & $\begin{array}{c}\text { Water } \\
\text { depth } \\
(\mathrm{m})\end{array}$ \\
\hline B3 & $44 \mathrm{f}$ & 91 & 102.4 & & & 13.28 & 37.22 & 28.3 \\
\hline B3 & $44 \mathrm{c}$ & & 39.8 & 142.2 & 0.72 & & & \\
\hline B19 & $54 \mathrm{f}$ & 91 & 14.8 & & & 19.10 & 40.63 & 21.5 \\
\hline B19 & $54 \mathrm{c}$ & & 50.1 & 64.9 & 0.23 & & & \\
\hline B18 & $55 \mathrm{f}$ & 91 & 37 & & & 23.22 & 40.52 & 29.0 \\
\hline B18 & $55 c$ & & 62.3 & 99.3 & 0.37 & & & \\
\hline B21 & $56 f$ & 91 & 90.4 & & & 15.83 & 36.00 & 52.0 \\
\hline B21 & $56 c$ & & 33.2 & 123.6 & 0.73 & & & \\
\hline B22 & $57 f$ & 91 & 10.8 & & & 19.63 & 36.52 & 56.7 \\
\hline B22 & $57 c$ & & 40.5 & 51.3 & 0.21 & & & \\
\hline B24 & $59 f$ & 91 & 6 & & & 22.40 & 37.93 & 42.1 \\
\hline B24 & $59 c$ & & 49.4 & 55.4 & 0.11 & & & \\
\hline C11 & $66 f$ & 91 & 52.6 & & & 22.15 & 29.93 & 25.2 \\
\hline C11 & $66 c$ & & 54.4 & 107 & 0.49 & & & \\
\hline $\mathrm{C} 8$ & $68 f$ & 91 & 97.6 & & & 20.33 & 40.37 & 40.7 \\
\hline $\mathrm{C} 8$ & $68 c$ & & 6.65 & 104.25 & 0.94 & & & \\
\hline B2 & $69 f$ & 91 & 98.9 & & & 15.70 & 39.50 & 52.0 \\
\hline B2 & $69 c$ & & 8.3 & 107.2 & 0.92 & & & \\
\hline B4 & $45 f$ & 91 & 17.3 & & & 13.78 & 34.77 & 32.0 \\
\hline B4 & $45 c$ & & 103.3 & 120.6 & 0.14 & & & \\
\hline B6 & $46 f$ & 91 & 90.3 & & & 15.83 & 33.00 & 31.1 \\
\hline B6 & $46 c$ & & 44.7 & 135 & 0.67 & & & \\
\hline B7 & $47 f$ & 91 & 71.3 & & & 18.00 & 31.55 & 49.6 \\
\hline B7 & $47 c$ & & 51.7 & 123 & 0.58 & & & \\
\hline B8 & $48 \mathrm{f}$ & 91 & 73.5 & & & 21.16 & 31.63 & 43.7 \\
\hline B8 & $48 c$ & & 62.3 & 135.8 & 0.54 & & & \\
\hline B10 & $49 f$ & 91 & 14.1 & & & 27.82 & 29.90 & 73.2 \\
\hline B10 & $49 c$ & & 103.3 & 117.4 & 0.12 & & & \\
\hline B11 & $51 \mathrm{f}$ & 91 & 58.1 & & & 27.65 & 30.73 & 30.8 \\
\hline B11 & 51c & & 65.5 & 123.6 & 0.47 & & & \\
\hline B16 & $53 \mathrm{f}$ & 91 & 29.6 & & & 26.17 & 39.52 & 20.0 \\
\hline B16 & $53 c$ & & 51.5 & 81.1 & 0.36 & & & \\
\hline B23 & $58 f$ & 91 & 68.3 & & & 18.82 & 33.66 & 48.6 \\
\hline B23 & $58 c$ & & 58.2 & 126.5 & 0.54 & & & \\
\hline B25 & $60 f$ & 91 & 26.2 & & & 21.86 & 35.33 & 50.4 \\
\hline B25 & $60 c$ & & 81.7 & 107.9 & 0.24 & & & \\
\hline B26 & $61 f$ & 91 & 2.75 & & & 26.58 & 36.20 & 44.8 \\
\hline B26 & $61 c$ & & 40.6 & 43.35 & 0.06 & & & \\
\hline
\end{tabular}


Appendix A. (Continued).

\begin{tabular}{|c|c|c|c|c|c|c|c|c|}
\hline $\begin{array}{c}\text { Station } \\
\text { No }\end{array}$ & $\begin{array}{c}\text { MSC } \\
\text { No }\end{array}$ & $\begin{array}{c}\text { Volume } \\
\text { total } \\
\text { sample } \\
\left(\mathrm{cm}^{3}\right)\end{array}$ & $\begin{array}{l}\text { Dry wt } \\
\quad \text { fine } \\
\text { and coarse } \\
\text { fraction }(g)\end{array}$ & $\begin{array}{c}\text { Total } \\
\text { dry } \\
\text { sample wt } \\
\text { (g) }\end{array}$ & $\begin{array}{c}\text { Fines } \\
\text { (fraction } \\
\text { of total } \\
\text { dry wt) }\end{array}$ & $\begin{array}{c}\text { Minutes } \\
\text { east of } \\
165^{\circ} \mathrm{E} \\
X \text {-coord }\end{array}$ & $\begin{array}{c}\text { Minutes } \\
\text { north of } \\
11^{\circ} \mathrm{N} \\
Y \text {-coord }\end{array}$ & $\begin{array}{l}\text { Water } \\
\text { depth } \\
\text { (m) }\end{array}$ \\
\hline B15 & $64 f$ & 91 & 51.9 & & & 30.88 & 36.63 & 31.7 \\
\hline B15 & $64 c$ & & 50.7 & 102.6 & 0.51 & & & \\
\hline C6 & $29 f$ & 91 & 91 & & & 20.30 & 40.37 & 38.2 \\
\hline C6 & $29 c$ & & 19.6 & 110.6 & 0.82 & & & \\
\hline
\end{tabular}

$\mathrm{f}=$ fine; $\mathrm{c}=$ coarse 
Appendix B

Description of Bikini Lagoon Sediment Cores Collected During 10-11/1972 

Appendix B. Description of Bikini lagoon sediment cores collected during 10-11/1972.

\begin{tabular}{|c|c|c|c|c|c|c|c|c|}
\hline $\begin{array}{c}\text { Station } \\
\text { number } \\
\& \text { date } \\
\text { collected }\end{array}$ & $\begin{array}{l}\text { Depth } \\
\text { increment } \\
\text { (cm) }\end{array}$ & $\begin{array}{l}\begin{array}{l}\text { Volume } \\
\text { total }\end{array} \\
\text { sample } \\
\left(\mathrm{cm}^{3}\right)\end{array}$ & $\begin{array}{l}\text { Dry wt } \\
\text { fine and } \\
\text { coarse } \\
\text { fraction }(g)\end{array}$ & $\begin{array}{c}\text { Total } \\
\text { dry } \\
\text { sample wt } \\
\text { (g) }\end{array}$ & $\begin{array}{c}\text { Fines } \\
\text { (fraction } \\
\text { of } \\
\text { total wt) }\end{array}$ & $\begin{array}{c}\text { Minutes } \\
\text { east of } \\
165^{\circ} \mathrm{E} \\
X \text {-coord }\end{array}$ & $\begin{array}{c}\text { Minutes } \\
\text { north of } \\
11^{\circ} \mathrm{N} \\
Y \text {-coord }\end{array}$ & $\begin{array}{c}\text { Water } \\
\text { depth } \\
\text { (m) }\end{array}$ \\
\hline B-3 & $0-5 f$ & 181.6 & 111.1 & & & 13.28 & 37.22 & 28.3 \\
\hline \multirow[t]{13}{*}{$11 / 8 / 72$} & $0-5 c$ & & 132 & 243.1 & 0.46 & & & \\
\hline & $5-10 f$ & 181.6 & 48.9 & & & & & \\
\hline & $5-10 c$ & & 115 & 163.9 & 0.30 & & & \\
\hline & 10-15f & 181.6 & 52.7 & & & & & \\
\hline & $10-15 c$ & & 116.5 & 169.2 & 0.31 & & & \\
\hline & 15-20f & 181.6 & 50.4 & & & & & \\
\hline & $15-20 c$ & & 102.2 & 152.6 & 0.33 & & & \\
\hline & $20-25 f$ & 181.6 & 53.4 & & & & & \\
\hline & $20-25 c$ & & 108.5 & 161.9 & 0.33 & & & \\
\hline & 25-30f & 181.6 & 56.3 & & & & & \\
\hline & $25-30 c$ & & 123.3 & 179.6 & 0.31 & & & \\
\hline & $30-35 f$ & 181.6 & 47.8 & & & & & \\
\hline & $30-35 c$ & & 122.9 & 170.7 & 0.28 & & & \\
\hline B-4 & $0-3$ & 109 & 88.6 & 88.6 & & 13.78 & 34.77 & 32 \\
\hline \multirow[t]{2}{*}{$11 / 8 / 72$} & $3-6$ & 109 & 123.3 & 123.3 & & & & \\
\hline & $6-7$ & 36.3 & 30.3 & 30.3 & & & & \\
\hline B-16 & $0-3$ & 109 & 119.9 & 119.9 & & 27.17 & 39.52 & 20 \\
\hline \multirow[t]{4}{*}{$11 / 4 / 72$} & $3-6$ & 109 & 97.3 & 97.3 & & & & \\
\hline & $6-9$ & 109 & 97.7 & 97.7 & & & & \\
\hline & $9-12$ & 109 & 97.2 & 97.2 & & & & \\
\hline & $12-15$ & 109 & 97.2 & 97.2 & & & & \\
\hline B-18 & $0-3$ & 109 & 122.1 & 122.1 & & 23.22 & 40.52 & 29 \\
\hline \multirow[t]{3}{*}{$11 / 4 / 72$} & $3-6$ & 109 & 109.1 & 109.1 & & & & \\
\hline & $6-9$ & 109 & 121.2 & 121.2 & & & & \\
\hline & 9-10.5 & 54.5 & 61.2 & 61.2 & & & & \\
\hline B-20 & $0-5 f$ & 181.6 & 180.1 & & & & & \\
\hline \multirow[t]{5}{*}{$11 / 8 / 72$} & $0-5 c$ & & 11.56 & 191.66 & 0.94 & 16.38 & 38.5 & 56 \\
\hline & $5-10 f$ & 181.6 & 184.2 & & & & & \\
\hline & $5-10 c$ & & 9.48 & 193.68 & 0.95 & & & \\
\hline & $10-15 f$ & 181.6 & 96.7 & & & & & \\
\hline & $10-15 c$ & & 69.3 & 166 & 0.58 & & & \\
\hline
\end{tabular}


Appendix B. (Continued).

\begin{tabular}{|c|c|c|c|c|c|c|c|c|}
\hline $\begin{array}{l}\text { Station } \\
\text { number } \\
\text { \& date } \\
\text { collected }\end{array}$ & $\begin{array}{l}\text { Depth } \\
\text { increment } \\
(\mathrm{cm})\end{array}$ & $\begin{array}{c}\begin{array}{c}\text { Volume } \\
\text { total }\end{array} \\
\text { sample } \\
\left(\mathrm{cm}^{3}\right)\end{array}$ & $\begin{array}{l}\text { Dry wt } \\
\text { fine and } \\
\text { coarse } \\
\text { fraction }(g)\end{array}$ & $\begin{array}{c}\text { Total } \\
\text { dry } \\
\text { sample wt } \\
\text { (g) }\end{array}$ & $\begin{array}{l}\text { Fines } \\
\text { (fraction } \\
\text { of } \\
\text { total wt) }\end{array}$ & $\begin{array}{c}\text { Minutes } \\
\text { east of } \\
165^{\circ} \mathrm{E} \\
X \text {-coord }\end{array}$ & $\begin{array}{c}\text { Minutes } \\
\text { north of } \\
11^{\circ} \mathrm{N} \\
\text { Y-coord }\end{array}$ & $\begin{array}{c}\text { Water } \\
\text { depth } \\
(\mathrm{m})\end{array}$ \\
\hline B-25 & $0-3$ & 109 & 70.9 & 70.9 & & 21.86 & 35.33 & 50.4 \\
\hline \multirow[t]{5}{*}{$11 / 5 / 72$} & $3-6$ & 109 & 83.3 & 83.3 & & & & \\
\hline & $6-9$ & 109 & 90.7 & 90.7 & & & & \\
\hline & 9-12 & 109 & 96.7 & 96.7 & & & & \\
\hline & $12-15$ & 109 & 100.1 & 100.1 & & & & \\
\hline & $15-18$ & 109 & 98.4 & 98.4 & & & & \\
\hline$C-2$ & $0-6$ & 218 & 86 & 86 & & 16.62 & 41.47 & 47.1 \\
\hline $11 / 13 / 72$ & $6-12$ & 218 & 154.5 & 154.5 & & & & \\
\hline Bravo & $12-18$ & 218 & 187.8 & 187.8 & & & & \\
\hline \multirow[t]{17}{*}{ Crater } & $18-24$ & 218 & 183 & 183 & & & & \\
\hline & $24-30$ & 218 & 177.4 & 177.4 & & & & \\
\hline & $30-36$ & 218 & 192 & 192 & & & & \\
\hline & $36-42$ & 218 & 187.3 & 187.3 & & & & \\
\hline & $42-48$ & 218 & 195 & 195 & & & & \\
\hline & $48-54$ & 218 & 182 & 182 & & & & \\
\hline & $54-60$ & 218 & 229.2 & 229.2 & & & & \\
\hline & $60-66$ & 218 & 201 & 201 & & & & \\
\hline & $66-72$ & 218 & 194.8 & 194.8 & & & & \\
\hline & $72-78$ & 218 & 191.4 & 191.4 & & & & \\
\hline & $78-84$ & 218 & 198.8 & 198.8 & & & & \\
\hline & $84-90$ & 218 & 209.8 & 209.8 & & & & \\
\hline & $90-96$ & 218 & 215 & 215 & & & & \\
\hline & 96-102 & 218 & 217 & 217 & & & & \\
\hline & 102-108 & 218 & 210 & 210 & & & & \\
\hline & 108-114 & 218 & 202 & 202 & & & & \\
\hline & 114-120 & 218 & 228 & 228 & & & & \\
\hline$C-3$ & $0-6$ & 218 & 213 & 213 & & 16.17 & 41.42 & 47.4 \\
\hline $11 / 13 / 72$ & $6-12$ & 218 & 196.1 & 196.1 & & & & \\
\hline Bravo & $12-18$ & 218 & 236.2 & 236.2 & & & & \\
\hline \multirow[t]{5}{*}{ Crater } & $18-24$ & 218 & 237.2 & 237.2 & & & & \\
\hline & $24-30$ & 218 & 240.1 & 240.1 & & & & \\
\hline & 30-36 & 218 & 234.6 & 234.6 & & & & \\
\hline & $36-42$ & 218 & 231.8 & 231.8 & & & & \\
\hline & $42-48$ & 218 & 237.7 & 237.7 & & & & \\
\hline
\end{tabular}


Appendix B. (Continued).

\begin{tabular}{|c|c|c|c|c|c|c|c|c|}
\hline $\begin{array}{c}\text { Station } \\
\text { number } \\
\text { \& date } \\
\text { collected }\end{array}$ & $\begin{array}{l}\text { Depth } \\
\text { increment } \\
(\mathrm{cm})\end{array}$ & $\begin{array}{c}\begin{array}{c}\text { Volume } \\
\text { total }\end{array} \\
\text { sample } \\
\left(\mathrm{cm}^{3}\right)\end{array}$ & $\begin{array}{c}\text { Dry wt } \\
\text { fine and } \\
\text { coarse } \\
\text { fraction }(g)\end{array}$ & $\begin{array}{c}\text { Total } \\
\text { dry } \\
\text { sample wt } \\
\text { (g) }\end{array}$ & 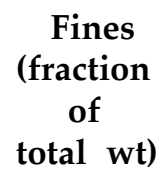 & $\begin{array}{c}\text { Minutes } \\
\text { east of } \\
165^{\circ} \mathrm{E} \\
X \text {-coord }\end{array}$ & $\begin{array}{c}\text { Minutes } \\
\text { north of } \\
11^{\circ} \mathrm{N} \\
Y \text {-coord }\end{array}$ & $\begin{array}{c}\text { Water } \\
\text { depth } \\
\text { (m) }\end{array}$ \\
\hline C-1 & $0-6$ & 218 & 249.5 & 249.5 & & 16.88 & 41.5 & 45 \\
\hline $11 / 13 / 72$ & $6-12$ & 218 & 268.1 & 268.1 & & & & \\
\hline Bravo & $12-18$ & 218 & 257.4 & 257.4 & & & & \\
\hline \multirow[t]{4}{*}{ Crater } & $18-24$ & 218 & 250 & 250 & & & & \\
\hline & $24-30$ & 218 & 264.2 & 264.2 & & & & \\
\hline & $30-36$ & 218 & 257.4 & 257.4 & & & & \\
\hline & $36-41$ & 182 & 200.5 & 200.5 & & & & \\
\hline C-11 & $0-6$ & 218 & 281 & 281 & & 22.15 & 29.93 & 28 \\
\hline $11 / 14 / 72$ & $6-12$ & 218 & 259.1 & 259.1 & & & & \\
\hline Zuni & $12-18$ & 218 & 257 & 257 & & & & \\
\hline \multirow[t]{2}{*}{ Crater } & $18-24$ & 218 & 255.6 & 255.6 & & & & \\
\hline & $24-31$ & 182 & 273.5 & 273.5 & & & & \\
\hline C-8 & $0-6$ & 218 & 190.5 & 190.5 & & 20.33 & 40.37 & 40.7 \\
\hline $11 / 14 / 72$ & $6-12$ & 218 & 237.2 & 237.2 & & & & \\
\hline Tewa & $12-17.5$ & 200 & 231 & 231 & & & & \\
\hline \multicolumn{9}{|l|}{ Crater } \\
\hline B-15 & $0-2.5 f$ & 90.8 & 44.4 & & & 30.88 & 36.63 & 31.7 \\
\hline \multirow[t]{9}{*}{$10 / 31 / 72$} & $0-2.5 c$ & 90.8 & 39.7 & 84.1 & 0.53 & & & \\
\hline & $2.5-5.0 \mathrm{f}$ & 90.8 & 68.8 & & & & & \\
\hline & $2.5-5.0 \mathrm{c}$ & 90.8 & 57.2 & 126 & 0.55 & & & \\
\hline & $5.0-7.5 \mathrm{f}$ & 90.8 & 50.5 & & & & & \\
\hline & $5.0-7.5 c$ & 90.8 & 79.7 & 130.2 & 0.39 & & & \\
\hline & 7.5-10.0f & 90.8 & 42.7 & & & & & \\
\hline & $7.5-10.0 \mathrm{c}$ & 90.8 & 62 & 104.7 & 0.41 & & & \\
\hline & $10.0-12.5 f$ & 90.8 & 29.4 & & & & & \\
\hline & $10.0-12.5 c$ & 90.8 & 70.6 & 100 & 0.29 & & & \\
\hline
\end{tabular}

All cores: diameter $=6.8 \mathrm{~cm}$; area $=36.32 \mathrm{~cm}^{2}$. $\mathrm{f}=$ fine; $\mathrm{c}=$ coarse fraction 

Appendix C

Description of Bikini Lagoon Surface Sediments $(0-2 \mathrm{~cm})$ Collected During 4-6/1979 

Appendix C. Description of Bikini lagoon surface sediments (0-2 cm) collected during 4-6/1979.

\begin{tabular}{|c|c|c|c|c|c|c|c|c|}
\hline $\log I D$ & $\begin{array}{c}\text { MS } \\
\text { number }\end{array}$ & $\begin{array}{c}\text { Volume } \\
\text { total } \\
\text { sample } \\
\left(\mathrm{cm}^{3}\right)\end{array}$ & $\begin{array}{l}\text { Dry wt } \\
\text { fine and } \\
\text { coarse } \\
\text { fraction }(g)\end{array}$ & $\begin{array}{c}\text { Total } \\
\text { dry } \\
\text { sample wt } \\
\text { (g) }\end{array}$ & $\begin{array}{c}\text { Fines } \\
\text { (fraction } \\
\text { of } \\
\text { total wt) }\end{array}$ & $\begin{array}{c}\text { Minutes } \\
\text { east of } \\
165^{\circ} \mathrm{E} \\
X \text {-coord }\end{array}$ & $\begin{array}{l}\text { Minutes } \\
\text { north of } \\
11^{\circ} \mathrm{N} \\
\text { Y-coord }\end{array}$ & $\begin{array}{l}\text { Water } \\
\text { depth } \\
\text { (m) }\end{array}$ \\
\hline $4 / 22 / 79-1 F$ & 7400 & 117.9 & 110.37 & & & 33.5 & 31 & 6 \\
\hline C & 7401 & & 36.71 & 147.08 & 0.75 & & & \\
\hline $2 \mathrm{~F}$ & 2 & 117.9 & 25.93 & & & 32.5 & 30 & 25 \\
\hline C & 3 & & 121.3 & 147.23 & 0.18 & & & \\
\hline $3 F$ & 4 & 117.9 & 63.21 & & & 32.5 & 31.5 & 49 \\
\hline C & 5 & & 71.52 & 134.73 & 0.47 & & & \\
\hline $4 \mathrm{~F}$ & 8 & 117.9 & 65.81 & & & 32.5 & 33 & 38 \\
\hline C & 9 & & 90.14 & 155.95 & 0.42 & & & \\
\hline $5 \mathrm{~F}$ & 12 & 117.9 & 33.47 & & & 32.5 & 34.5 & 31 \\
\hline C & 13 & & 77.68 & 111.15 & 0.30 & & & \\
\hline $6 \mathrm{~F}$ & 16 & 117.9 & 144.06 & & & 32.5 & 36 & 21 \\
\hline C & 17 & & 17.28 & 161.34 & 0.89 & & & \\
\hline $7 \mathrm{~F}$ & 18 & 117.9 & 14.02 & & & 31 & 37.5 & 25 \\
\hline $\mathrm{C}$ & 19 & & 58.84 & 72.86 & 0.19 & & & \\
\hline $9 \mathrm{~F}$ & 22 & 78.6 & 33.37 & & & 28 & 37.5 & $29-39$ \\
\hline $\mathrm{C}$ & 23 & & 63.59 & 96.96 & 0.34 & & & \\
\hline $10 \mathrm{~F}$ & 24 & 117.9 & 20.27 & & & 26.5 & 37.5 & 49 \\
\hline C & 25 & & 98.87 & 119.14 & 0.17 & & & \\
\hline $11 \mathrm{~F}$ & 28 & 117.9 & 3.77 & & & 26.5 & 36 & 49 \\
\hline $\mathrm{C}$ & 29 & & 54.36 & 58.13 & 0.06 & & & \\
\hline $12 \mathrm{~F}$ & 32 & 117.9 & 4.58 & & & 28 & 36 & 51 \\
\hline C & 33 & & 56 & 60.58 & 0.08 & & & \\
\hline $13 \mathrm{~F}$ & 36 & 117.9 & 7.94 & & & 29.5 & 36 & 45 \\
\hline C & 37 & & 70.23 & 78.17 & 0.10 & & & \\
\hline $14 \mathrm{~F}$ & 40 & 117.9 & 93.35 & & & 31 & 36 & 48 \\
\hline $\mathrm{C}$ & 41 & & 64.45 & 157.8 & 0.59 & & & \\
\hline $4 / 23 / 79-1 F$ & 42 & 117.9 & 57.86 & & & 29.5 & 34.5 & 54 \\
\hline $\mathrm{C}$ & 43 & & 94 & 151.86 & 0.38 & & & \\
\hline $2 \mathrm{~F}$ & 46 & 117.9 & 23.17 & & & 29.5 & 33 & 56 \\
\hline $\mathrm{C}$ & 47 & & 77.03 & 100.2 & 0.23 & & & \\
\hline $3 F$ & 50 & 117.9 & 70.72 & & & 29.5 & 31.5 & 44 \\
\hline $\mathrm{C}$ & 51 & & 102.15 & 172.87 & 0.41 & & & \\
\hline $4 / 24 / 79-1 F$ & 54 & 117.9 & 66.47 & & & 26.5 & 31.5 & 42 \\
\hline C & 55 & & 92.22 & 158.69 & 0.42 & & & \\
\hline $2 \mathrm{Fa}$ & 58 & 117.9 & 10.6 & & & 26.5 & 33 & $52-54$ \\
\hline C & 59 & & 73.9 & 84.5 & 0.13 & & & \\
\hline $2 \mathrm{Fb}$ & 62 & 117.9 & 26.9 & & & & & \\
\hline $\mathrm{C}$ & 63 & & 73.8 & 100.7 & 0.27 & & & \\
\hline $3 F a$ & 66 & 117.9 & 3.7 & & & 26.5 & 34.5 & $52-53$ \\
\hline
\end{tabular}


Appendix C. (Continued).

\begin{tabular}{|c|c|c|c|c|c|c|c|c|}
\hline LogID & $\begin{array}{c}\text { MS } \\
\text { number }\end{array}$ & $\begin{array}{c}\text { Volume } \\
\text { total } \\
\text { sample } \\
\left(\mathrm{cm}^{3}\right)\end{array}$ & $\begin{array}{l}\text { Dry wt } \\
\text { fine and } \\
\text { coarse } \\
\text { fraction }(g)\end{array}$ & $\begin{array}{c}\text { Total } \\
\text { dry } \\
\text { sample wt } \\
\text { (g) }\end{array}$ & $\begin{array}{c}\text { Fines } \\
\text { (fraction } \\
\text { of } \\
\text { total wt) }\end{array}$ & $\begin{array}{c}\text { Minutes } \\
\text { east of } \\
165^{\circ} \mathrm{E} \\
X \text {-coord }\end{array}$ & $\begin{array}{l}\text { Minutes } \\
\text { north of } \\
11^{\circ} \mathrm{N} \\
Y \text {-coord }\end{array}$ & $\begin{array}{l}\text { Water } \\
\text { depth } \\
\text { (m) }\end{array}$ \\
\hline C & 67 & & 55.6 & 59.3 & 0.06 & & & \\
\hline $3 \mathrm{Fb}$ & 70 & 117.9 & 2.1 & & & & & \\
\hline $\mathrm{C}$ & 71 & & 56 & 58.1 & 0.04 & & & \\
\hline $4 \mathrm{~F}$ & 74 & 117.9 & 26.1 & & & 25 & 34.5 & 52 \\
\hline $\mathrm{C}$ & 75 & & 94.7 & 120.8 & 0.22 & & & \\
\hline $5 \mathrm{~F}$ & 78 & 117.9 & 1.9 & & & 23.5 & 34.5 & 54 \\
\hline $\mathrm{C}$ & 79 & & 61.1 & 63 & 0.03 & & & \\
\hline $6 \mathrm{~F}$ & 82 & 117.9 & 8.2 & & & 22 & 34.5 & 54 \\
\hline $\mathrm{C}$ & 83 & & 55.8 & 64 & 0.13 & & & \\
\hline $7 F$ & 86 & 117.9 & 7.2 & & & 20.5 & 34.5 & 47 \\
\hline C & 87 & & 59.6 & 66.8 & 0.11 & & & \\
\hline $8 \mathrm{~F}$ & 90 & 117.9 & 82.2 & & & 19 & 34.5 & 49 \\
\hline$C$ & 91 & & 81.3 & 163.5 & 0.50 & & & \\
\hline $9 \mathrm{Fa}$ & 92 & 117.9 & 66.7 & & & 17.5 & 34.5 & 54 \\
\hline$C$ & 93 & & 47.2 & 113.9 & 0.59 & & & \\
\hline $9 \mathrm{Fb}$ & 94 & 117.9 & 102.2 & & & & & \\
\hline C & 95 & & 57.9 & 160.1 & 0.64 & & & \\
\hline $10 \mathrm{~F}$ & 96 & 117.9 & 145 & & & 16 & 34.5 & 48 \\
\hline C & 97 & & 44.4 & 189.4 & 0.77 & & & \\
\hline $11 \mathrm{~F}$ & 7500 & 117.9 & 113.3 & & & 14.5 & 34.5 & 44 \\
\hline C & 1 & & 61.5 & 174.8 & 0.65 & & & \\
\hline $12 \mathrm{~F}$ & 4 & 117.9 & 125.5 & & & 14.5 & 36 & 40 \\
\hline C & 5 & & 43 & 168.5 & 0.74 & & & \\
\hline $13 \mathrm{~F}$ & 8 & 117.9 & 26.7 & & & 16 & 36 & 54 \\
\hline C & 9 & & 85.2 & 111.9 & 0.24 & & & \\
\hline $14 \mathrm{~F}$ & 10 & 117.9 & 63.9 & & & 16 & 37.5 & 40 \\
\hline C & 11 & & 81.3 & 145.2 & 0.44 & & & \\
\hline $15 \mathrm{~F}$ & 12 & 117.9 & 116.4 & & & 17.5 & 39 & 56 \\
\hline$C$ & 13 & & 32 & 148.4 & 0.78 & & & \\
\hline $17 \mathrm{~F}$ & 20 & 117.9 & 145.2 & & & 20.5 & 39 & 59 \\
\hline$C$ & 21 & & 0.7 & 145.9 & 1.00 & & & \\
\hline $4 / 25 / 79-1 F$ & 24 & 117.9 & 56.5 & & & 19 & 40.5 & $39-44$ \\
\hline $\mathrm{C}$ & 25 & & 52.7 & 109.2 & 0.52 & & & \\
\hline $2 \mathrm{~F}$ & 28 & 117.9 & 41.5 & & & 19 & 37.5 & 56 \\
\hline $\mathrm{C}$ & 29 & & 72.3 & 113.8 & 0.36 & & & \\
\hline $3 F$ & 32 & 117.9 & 14.3 & & & 19 & 36 & $46-52$ \\
\hline $\mathrm{C}$ & 33 & & 99.9 & 114.2 & 0.13 & & & \\
\hline $4 \mathrm{~F}$ & 36 & 117.9 & 106.7 & & & 19 & 33 & 51 \\
\hline $\mathrm{C}$ & 37 & & 65.5 & 172.2 & 0.62 & & & \\
\hline
\end{tabular}


Appendix C. (Continued).

\begin{tabular}{|c|c|c|c|c|c|c|c|c|}
\hline $\log I D$ & $\begin{array}{c}\text { MS } \\
\text { number }\end{array}$ & $\begin{array}{c}\text { Volume } \\
\text { total } \\
\text { sample } \\
\left(\mathrm{cm}^{3}\right)\end{array}$ & $\begin{array}{l}\text { Dry wt } \\
\text { fine and } \\
\text { coarse } \\
\text { fraction }(g)\end{array}$ & $\begin{array}{l}\text { Total } \\
\text { dry } \\
\text { sample wt } \\
\text { (g) }\end{array}$ & $\begin{array}{c}\text { Fines } \\
\text { (fraction } \\
\text { of } \\
\text { total wt) }\end{array}$ & $\begin{array}{c}\text { Minutes } \\
\text { east of } \\
165^{\circ} \mathrm{E} \\
X \text {-coord }\end{array}$ & $\begin{array}{c}\text { Minutes } \\
\text { north of } \\
11^{\circ} \mathrm{N} \\
Y \text {-coord }\end{array}$ & $\begin{array}{c}\text { Water } \\
\text { depth } \\
\text { (m) }\end{array}$ \\
\hline $5 \mathrm{~F}$ & 40 & 117.9 & 113.9 & & & 19 & 31.5 & 48 \\
\hline C & 41 & & 66.2 & 180.1 & 0.63 & & & \\
\hline $6 \mathrm{~F}$ & 44 & 117.9 & 102.3 & & & 21.25 & 29.75 & 31 \\
\hline C & 45 & & 70.6 & 172.9 & 0.59 & & & \\
\hline 6/15/79-1F & 48 & 78.6 & 102.5 & & & 33.3 & 30.9 & \\
\hline C & 49 & & 4.5 & 107 & 0.96 & & & \\
\hline $2 \mathrm{~F}$ & 52 & 78.6 & 66.9 & & & 31 & 31.5 & 48 \\
\hline C & 53 & & 35.6 & 102.5 & 0.65 & & & \\
\hline $3 F$ & 56 & 78.6 & 58.5 & & & 28 & 31.5 & 46 \\
\hline $\mathrm{C}$ & 57 & & 44.4 & 102.9 & 0.57 & & & \\
\hline $4 \mathrm{~F}$ & 60 & 78.6 & 44 & & & 25 & 31.5 & 44 \\
\hline $\mathrm{C}$ & 61 & & 61 & 105 & 0.42 & & & \\
\hline $5 \mathrm{~F}$ & 64 & 78.6 & 7.4 & & & 23.5 & 31.5 & 48 \\
\hline $\mathrm{C}$ & 65 & & 47.7 & 55.1 & 0.13 & & & \\
\hline $6 \mathrm{~F}$ & 68 & 78.6 & 76.5 & & & 22 & 31.5 & 44 \\
\hline $\mathrm{C}$ & 69 & & 82.5 & 159 & 0.48 & & & \\
\hline $7 F$ & 72 & 78.6 & 41 & & & 20.5 & 31.5 & 42 \\
\hline $\mathrm{C}$ & 73 & & 66.3 & 107.3 & 0.38 & & & \\
\hline $8 \mathrm{~F}$ & 76 & 78.6 & 73.7 & & & 17.5 & 31.5 & 36 \\
\hline $\mathrm{C}$ & 77 & & 36.7 & 110.4 & 0.67 & & & \\
\hline $9 F$ & 80 & 78.6 & 34.1 & & & 16 & 32.8 & 32 \\
\hline $\mathrm{C}$ & 81 & & 69.4 & 103.5 & 0.33 & & & \\
\hline $10 \mathrm{~F}$ & 84 & 78.6 & 67.3 & & & 17.5 & 32.8 & 45 \\
\hline $\mathrm{C}$ & 85 & & 47.5 & 114.8 & 0.59 & & & \\
\hline $11 \mathrm{~F}$ & 88 & 78.6 & 63.8 & & & 20.5 & 32.8 & 54 \\
\hline $\mathrm{C}$ & 89 & & 35.5 & 99.3 & 0.64 & & & \\
\hline $12 \mathrm{~F}$ & 92 & 117.9 & 58.2 & & & 22 & 32.8 & 52 \\
\hline C & 93 & & 70.1 & 128.3 & 0.45 & & & \\
\hline $13 \mathrm{~F}$ & 96 & 78.6 & 70.2 & & & 23.5 & 32.8 & 57 \\
\hline C & 97 & & 36.6 & 106.8 & 0.66 & & & \\
\hline $14 \mathrm{~F}$ & 7600 & 78.6 & 17.2 & & & 25 & 32.8 & 54 \\
\hline C & 1 & & 53.2 & 70.4 & 0.24 & & & \\
\hline $15 \mathrm{~F}$ & 4 & 78.6 & 55.7 & & & 28 & 32.8 & 56 \\
\hline $\mathrm{C}$ & 5 & & 44.3 & 100 & 0.56 & & & \\
\hline $16 \mathrm{~F}$ & 8 & 78.6 & 7.5 & & & 28 & 34.3 & 59 \\
\hline C & 9 & & 52.9 & 60.4 & 0.12 & & & \\
\hline $17 \mathrm{~F}$ & 12 & 78.6 & 3.4 & & & 31 & 32.8 & 53 \\
\hline $\mathrm{C}$ & 13 & & 38.2 & 41.6 & 0.08 & & & \\
\hline $18 \mathrm{~F}$ & 16 & 78.6 & 2.9 & & & 31 & 34.3 & 47 \\
\hline
\end{tabular}


Appendix C. (Continued).

\begin{tabular}{|c|c|c|c|c|c|c|c|c|}
\hline LogID & $\begin{array}{c}\text { MS } \\
\text { number }\end{array}$ & $\begin{array}{c}\text { Volume } \\
\text { total } \\
\text { sample } \\
\left(\mathrm{cm}^{3}\right)\end{array}$ & $\begin{array}{l}\text { Dry wt } \\
\text { fine and } \\
\text { coarse } \\
\text { fraction }(g)\end{array}$ & $\begin{array}{c}\text { Total } \\
\text { dry } \\
\text { sample wt } \\
\text { (g) }\end{array}$ & $\begin{array}{c}\text { Fines } \\
\text { (fraction } \\
\text { of } \\
\text { total wt) }\end{array}$ & $\begin{array}{c}\text { Minutes } \\
\text { east of } \\
165^{\circ} \mathrm{E} \\
X \text {-coord }\end{array}$ & $\begin{array}{l}\text { Minutes } \\
\text { north of } \\
11^{\circ} \mathrm{N} \\
Y \text {-coord }\end{array}$ & $\begin{array}{c}\text { Water } \\
\text { depth } \\
\text { (m) }\end{array}$ \\
\hline $\mathrm{C}$ & 17 & & 41.8 & 44.7 & 0.06 & & & \\
\hline 6/16/79-1F & 20 & 78.6 & 26.5 & & & 26.5 & 39 & 38 \\
\hline $\mathrm{C}$ & 21 & & 41.9 & 68.4 & 0.39 & & & \\
\hline $2 \mathrm{~F}$ & 22 & 78.6 & 89.7 & & & 25 & 39 & 54 \\
\hline $\mathrm{C}$ & 23 & & 9.5 & 99.2 & 0.90 & & & \\
\hline $3 F$ & 24 & 78.6 & 57.3 & & & 25 & 40.5 & 20 \\
\hline $\mathrm{C}$ & 25 & & 23.5 & 80.8 & 0.71 & & & \\
\hline $4 \mathrm{~F}$ & 26 & 78.6 & 45 & & & 23.5 & 40.5 & 25 \\
\hline $\mathrm{C}$ & 27 & & 44.6 & 89.6 & 0.50 & & & \\
\hline $5 \mathrm{~F}$ & 28 & 78.6 & 29.8 & & & 22 & 40.2 & 20 \\
\hline $\mathrm{C}$ & 29 & & 33.8 & 63.6 & 0.47 & & & \\
\hline $6 \mathrm{~F}$ & 30 & 78.6 & 83.8 & & & 20.5 & 40.2 & 35 \\
\hline $\mathrm{C}$ & 31 & & 14.2 & 98 & 0.86 & & & \\
\hline $7 F$ & 32 & 78.6 & 37.5 & & & 17.5 & 40.2 & 45 \\
\hline $\mathrm{C}$ & 33 & & 47.3 & 84.8 & 0.44 & & & \\
\hline $8 \mathrm{~F}$ & 36 & 78.6 & 96.7 & & & 16 & 40.2 & 44 \\
\hline $\mathrm{C}$ & 37 & & 0.3 & 97 & 1.00 & & & \\
\hline $9 \mathrm{~F}$ & 38 & 78.6 & 91.9 & & & 16 & 39 & 59 \\
\hline C & 39 & & 1.7 & 93.6 & 0.98 & & & \\
\hline $10 \mathrm{~F}$ & 42 & 78.6 & 88.5 & & & 14.5 & 39 & 43 \\
\hline C & 43 & & 5.1 & 93.6 & 0.95 & & & \\
\hline $11 \mathrm{~F}$ & 46 & 78.6 & 41 & & & 14.5 & 37.8 & 48 \\
\hline C & 47 & & 51 & 92 & 0.45 & & & \\
\hline $12 \mathrm{~F}$ & 50 & 78.6 & 15.1 & & & 17.5 & 37.7 & 57 \\
\hline$C$ & 51 & & 53.2 & 68.3 & 0.22 & & & \\
\hline $13 \mathrm{~F}$ & 54 & 117.9 & 32.4 & & & 17.5 & 36 & 56 \\
\hline C & 55 & & 67.9 & 100.3 & 0.32 & & & \\
\hline $14 \mathrm{~F}$ & 58 & 117.9 & 5.7 & & & 20.5 & 36 & 55 \\
\hline$C$ & 59 & & 68.1 & 73.8 & 0.08 & & & \\
\hline $15 \mathrm{~F}$ & 62 & 117.9 & 3.1 & & & 22 & 36 & 55 \\
\hline $\mathrm{C}$ & 63 & & 51.1 & 54.2 & 0.06 & & & \\
\hline $16 \mathrm{~F}$ & 66 & 117.9 & 5.5 & & & 23.5 & 36 & 58 \\
\hline$C$ & 67 & & 61.6 & 67.1 & 0.08 & & & \\
\hline $17 \mathrm{~F}$ & 70 & 117.9 & 9.2 & & & 25 & 36 & 59 \\
\hline$C$ & 71 & & 59 & 68.2 & 0.13 & & & \\
\hline $18 \mathrm{~F}$ & 74 & 117.9 & 5.4 & & & 25 & 37.7 & 57 \\
\hline$C$ & 75 & & 51 & 56.4 & 0.10 & & & \\
\hline $19 \mathrm{~F}$ & 78 & 117.9 & 35 & & & 23.5 & 37.7 & 49 \\
\hline C & 79 & & 57.8 & 92.8 & 0.38 & & & \\
\hline
\end{tabular}


Appendix C. (Continued).

\begin{tabular}{|c|c|c|c|c|c|c|c|c|}
\hline LogID & $\begin{array}{c}\text { MS } \\
\text { number }\end{array}$ & $\begin{array}{c}\text { Volume } \\
\text { total } \\
\text { sample } \\
\left(\mathrm{cm}^{3}\right)\end{array}$ & $\begin{array}{l}\text { Dry wt } \\
\text { fine and } \\
\text { coarse } \\
\text { fraction }(g)\end{array}$ & $\begin{array}{l}\text { Total } \\
\text { dry } \\
\text { sample wt } \\
\text { (g) }\end{array}$ & $\begin{array}{c}\text { Fines } \\
\text { (fraction } \\
\text { of } \\
\text { total wt) }\end{array}$ & $\begin{array}{c}\text { Minutes } \\
\text { east of } \\
165^{\circ} \mathrm{E} \\
X \text {-coord }\end{array}$ & $\begin{array}{l}\text { Minutes } \\
\text { north of } \\
11^{\circ} \mathrm{N} \\
Y \text {-coord }\end{array}$ & $\begin{array}{c}\text { Water } \\
\text { depth } \\
\text { (m) }\end{array}$ \\
\hline $20 \mathrm{~F}$ & 82 & 117.9 & 5.4 & & & 22 & 37.7 & 57 \\
\hline C & 83 & & 56 & 61.4 & 0.09 & & & \\
\hline $21 \mathrm{~F}$ & 86 & 117.9 & 11 & & & 20.5 & 37.7 & 58 \\
\hline C & 87 & & 71.6 & 82.6 & 0.13 & & & \\
\hline $22 \mathrm{~F}$ & 90 & 117.9 & 60.5 & & & 22 & 39 & 48 \\
\hline C & 91 & & 65.1 & 125.6 & 0.48 & & & \\
\hline $23 \mathrm{~F}$ & 94 & 117.9 & 86.6 & & & 23.5 & 39 & 50 \\
\hline C & 95 & & 74.4 & 161 & 0.54 & & & \\
\hline 6/17/79-1F & 98 & 117.9 & 25.4 & & & 31 & 30.1 & 22 \\
\hline $\mathrm{C}$ & 99 & & 132.3 & 157.7 & 0.16 & & & \\
\hline $2 \mathrm{~F}$ & 7700 & 117.9 & 53.8 & & & 29.5 & 30.1 & 29 \\
\hline $\mathrm{C}$ & 1 & & 117.6 & 171.4 & 0.31 & & & \\
\hline $3 F$ & 4 & 117.9 & 24.3 & & & 28 & 30.1 & 13 \\
\hline $\mathrm{C}$ & 5 & & 146.5 & 170.8 & 0.14 & & & \\
\hline $4 \mathrm{~F}$ & 8 & 117.9 & 29.7 & & & 26.6 & 30.3 & 19 \\
\hline $\mathrm{C}$ & 9 & & 129.2 & 158.9 & 0.19 & & & \\
\hline $5 \mathrm{~F}$ & 12 & 117.9 & 76.8 & & & 25.2 & 30.3 & 36 \\
\hline $\mathrm{C}$ & 13 & & 90.5 & 167.3 & 0.46 & & & \\
\hline $6 \mathrm{~F}$ & 16 & 117.9 & 128.2 & & & 23.5 & 30.5 & 31 \\
\hline $\mathrm{C}$ & 17 & & 41.4 & 169.6 & 0.76 & & & \\
\hline $7 F$ & 20 & 117.9 & 114.5 & & & 22 & 30.1 & 24 \\
\hline$C$ & 21 & & 56.6 & 171.1 & 0.67 & & & \\
\hline $8 \mathrm{~F}$ & 24 & 117.9 & 128.6 & & & 20.5 & 30.4 & 34 \\
\hline C & 25 & & 70.5 & 199.1 & 0.65 & & & \\
\hline
\end{tabular}

$\mathrm{F}=$ fine; $\mathrm{C}=$ coarse fractions

Station locations provided by $X \& Y$ coordinates.

$\mathrm{a}$ and $\mathrm{b}$ samples are replicates $0-2 \mathrm{~cm}$ surface sections at station from different Shipek grab samples. 



\section{Appendix D}

Description of Bikini Lagoon Surface Sediments (0-4 cm)

Collected During 4-6/1979 

Appendix D. Description of Bikini lagoon sediments (0-4 cm surface sections) collected during 4-6/1979.

\begin{tabular}{|c|c|c|c|c|c|c|c|c|}
\hline LogID & $\begin{array}{c}\text { MS } \\
\text { number }\end{array}$ & $\begin{array}{c}\text { Volume } \\
\text { total } \\
\text { sample } \\
\left(\mathrm{cm}^{3}\right)\end{array}$ & $\begin{array}{l}\text { Dry wt } \\
\text { fine and } \\
\text { coarse } \\
\text { fraction }(g)\end{array}$ & $\begin{array}{l}\text { Total dry } \\
\text { sample } \\
\text { wt } \\
\text { (g) }\end{array}$ & $\begin{array}{c}\text { Fines } \\
\text { (fraction } \\
\text { of } \\
\text { total wt) }\end{array}$ & $\begin{array}{l}\text { Minutes } \\
\text { east of } \\
165^{\circ} \mathrm{E} \\
X \text {-coord }\end{array}$ & $\begin{array}{c}\text { Minutes } \\
\text { north of } \\
11^{\circ} \mathrm{N} \\
Y \text {-coord }\end{array}$ & $\begin{array}{l}\text { Water } \\
\text { depth } \\
\text { (m) }\end{array}$ \\
\hline $4 / 22 / 79-3 F$ & 7406 & 102.07 & 60.12 & & & 32.5 & 31.5 & 49 \\
\hline $\mathrm{C}$ & 7 & & 51.72 & 111.84 & 0.54 & & & \\
\hline $4 \mathrm{~F}$ & 10 & 102.07 & 57.88 & & & 32.5 & 33 & 38 \\
\hline $\mathrm{C}$ & 11 & & 78.87 & 136.75 & 0.42 & & & \\
\hline $5 \mathrm{~F}$ & 14 & 102.07 & 34.27 & & & 32.5 & 34.5 & 31 \\
\hline $\mathrm{C}$ & 15 & & 58.27 & 92.54 & 0.37 & & & \\
\hline $10 \mathrm{~F}$ & 26 & 102.07 & 21.48 & & & 26.5 & 37.5 & 49 \\
\hline $\mathrm{C}$ & 27 & & 83.09 & 104.57 & 0.21 & & & \\
\hline $11 \mathrm{~F}$ & 30 & 102.07 & 3.27 & & & 26.5 & 36 & 49 \\
\hline $\mathrm{C}$ & 31 & & 48.81 & 52.08 & 0.06 & & & \\
\hline $12 \mathrm{~F}$ & 34 & 102.07 & 5.03 & & & 28 & 36 & 51 \\
\hline $\mathrm{C}$ & 35 & & 55.43 & 60.46 & 0.08 & & & \\
\hline $13 \mathrm{~F}$ & 38 & 102.07 & 2.88 & & & 29.5 & 36 & 45 \\
\hline $\mathrm{C}$ & 39 & & 46.14 & 49.02 & 0.06 & & & \\
\hline $4 / 23 / 79-1 F$ & 44 & 102.07 & 57.46 & & & 29.5 & 34.5 & 54 \\
\hline $\mathrm{C}$ & 45 & & 88.22 & 145.68 & 0.39 & & & \\
\hline $2 \mathrm{~F}$ & 48 & 102.07 & 28.14 & & & 29.5 & 33 & 56 \\
\hline $\mathrm{C}$ & 49 & & 68.72 & 96.86 & 0.29 & & & \\
\hline $3 F$ & 52 & 102.07 & 71.69 & & & 29.5 & 31.5 & 44 \\
\hline $\mathrm{C}$ & 53 & & 77.09 & 148.78 & 0.48 & & & \\
\hline $4 / 24 / 79-1 F$ & 56 & 102.07 & 69.28 & & & 26.5 & 31.5 & 42 \\
\hline C & 57 & & 67.4 & 136.68 & 0.51 & & & \\
\hline $2 \mathrm{Fa}$ & 60 & 102.07 & 40.54 & & & 26.5 & 33 & $52-54$ \\
\hline$C$ & 61 & & 63.2 & 103.74 & 0.39 & & & \\
\hline $2 \mathrm{Fb}$ & 64 & 102.07 & 11.78 & & & & & \\
\hline$C$ & 65 & & 57.09 & 68.87 & 0.17 & & & \\
\hline $3 \mathrm{Fa}$ & 68 & 102.07 & 5.41 & & & 26.5 & 34.5 & $52-53$ \\
\hline$C$ & 69 & & 48.9 & 54.31 & 0.10 & & & \\
\hline $3 \mathrm{Fb}$ & 72 & 102.07 & 1.45 & & & & & \\
\hline$C$ & 73 & & 48.21 & 49.66 & 0.03 & & & \\
\hline $4 \mathrm{~F}$ & 76 & 102.07 & 32.42 & & & 25 & 34.5 & 52 \\
\hline$C$ & 77 & & 81.07 & 113.49 & 0.29 & & & \\
\hline $5 \mathrm{~F}$ & 80 & 102.07 & 2.56 & & & 23.5 & 34.5 & 54 \\
\hline $\mathrm{C}$ & 81 & & 52.15 & 54.71 & 0.05 & & & \\
\hline $6 \mathrm{~F}$ & 84 & 102.07 & 10.33 & & & 22 & 34.5 & 54 \\
\hline$C$ & 85 & & 52.13 & 62.46 & 0.17 & & & \\
\hline $7 F$ & 88 & 102.07 & 4.35 & & & 20.5 & 34.5 & 47 \\
\hline C & 89 & & 50.62 & 54.97 & 0.08 & & & \\
\hline $8 \mathrm{~F}$ & 9094 & 102.07 & 81.69 & & & 19 & 34.5 & 49 \\
\hline
\end{tabular}


Appendix D. (Continued).

\begin{tabular}{|c|c|c|c|c|c|c|c|c|}
\hline LogID & $\begin{array}{c}\text { MS } \\
\text { number }\end{array}$ & $\begin{array}{c}\text { Volume } \\
\text { total } \\
\text { sample } \\
\left(\mathrm{cm}^{3}\right)\end{array}$ & $\begin{array}{l}\text { Dry wt } \\
\text { fine and } \\
\text { coarse } \\
\text { fraction }(g)\end{array}$ & $\begin{array}{l}\text { Total dry } \\
\text { sample } \\
\text { wt } \\
\text { (g) }\end{array}$ & $\begin{array}{c}\text { Fines } \\
\text { (fraction } \\
\text { of } \\
\text { total wt) }\end{array}$ & $\begin{array}{l}\text { Minutes } \\
\text { east of } \\
165^{\circ} \mathrm{E} \\
X \text {-coord }\end{array}$ & $\begin{array}{c}\text { Minutes } \\
\text { north of } \\
11^{\circ} \mathrm{N} \\
Y \text {-coord }\end{array}$ & $\begin{array}{l}\text { Water } \\
\text { depth } \\
(\mathrm{m})\end{array}$ \\
\hline $\mathrm{C}$ & 9095 & & 67.16 & 148.85 & 0.55 & & & \\
\hline $10 \mathrm{~F}$ & 98 & 102.07 & 110.32 & & & 16 & 34.5 & 48 \\
\hline $\mathrm{C}$ & 99 & & 35.09 & 145.41 & 0.76 & & & \\
\hline $11 \mathrm{~F}$ & 7502 & 102.07 & 115.04 & & & 14.5 & 34.5 & 44 \\
\hline $\mathrm{C}$ & 3 & & 60.83 & 175.87 & 0.65 & & & \\
\hline $12 \mathrm{~F}$ & 6 & 102.07 & 100.82 & & & 14.5 & 36 & 40 \\
\hline $\mathrm{C}$ & 7 & & 31.77 & 132.59 & 0.76 & & & \\
\hline $13 \mathrm{~F}$ & 9096 & 102.07 & 17.63 & & & 16 & 36 & 54 \\
\hline $\mathrm{C}$ & 9097 & & 101.75 & 119.38 & 0.15 & & & \\
\hline $15 \mathrm{~F}$ & 14 & 102.07 & 107.11 & & & 17.5 & 39 & 56 \\
\hline $\mathrm{C}$ & 15 & & 28.92 & 136.03 & 0.79 & & & \\
\hline $15 \mathrm{bF}$ & 16 & 102.07 & 89.98 & & & & & \\
\hline $\mathrm{C}$ & 17 & & 50.69 & 140.67 & 0.64 & & & \\
\hline $17 \mathrm{~F}$ & 22 & 102.07 & 123.18 & & & 20.5 & 39 & 59 \\
\hline $\mathrm{C}$ & 23 & & 0.57 & 123.75 & 1.00 & & & \\
\hline $4 / 25 / 79-2 F$ & 30 & 102.07 & 47.6 & & & 19 & 37.5 & 56 \\
\hline $\mathrm{C}$ & 31 & & 69.26 & 116.86 & 0.41 & & & \\
\hline $3 F$ & 34 & 102.07 & 14.3 & & & 19 & 36 & $46-52$ \\
\hline $\mathrm{C}$ & 35 & & 89.27 & 103.57 & 0.14 & & & \\
\hline $4 \mathrm{~F}$ & 38 & 102.07 & 89.67 & & & 19 & 33 & 51 \\
\hline $\mathrm{C}$ & 39 & & 48.64 & 138.31 & 0.65 & & & \\
\hline $5 \mathrm{~F}$ & 42 & 102.07 & 93.62 & & & 19 & 31.5 & 48 \\
\hline $\mathrm{C}$ & 43 & & 61.93 & 155.55 & 0.60 & & & \\
\hline $6 \mathrm{~F}$ & 46 & 102.07 & 99.1 & & & 21.25 & 29.75 & 31 \\
\hline $\mathrm{C}$ & 47 & & 47.65 & 146.75 & 0.68 & & & \\
\hline 6/15/79-1F & 50 & 102.07 & 108.46 & & & 33.3 & 30.9 & \\
\hline $\mathrm{C}$ & 51 & & 3.03 & 111.49 & 0.97 & & & \\
\hline $2 \mathrm{~F}$ & 54 & 102.07 & 90.14 & & & 31 & 31.5 & 48 \\
\hline $\mathrm{C}$ & 55 & & 45.95 & 136.09 & 0.66 & & & \\
\hline $3 F$ & 58 & 102.07 & 74.22 & & & 28 & 31.5 & 46 \\
\hline $\mathrm{C}$ & 59 & & 48.56 & 122.78 & 0.60 & & & \\
\hline $4 \mathrm{~F}$ & 62 & 102.07 & 31.16 & & & 25 & 31.5 & 44 \\
\hline $\mathrm{C}$ & 63 & & 81.23 & 112.39 & 0.28 & & & \\
\hline $5 \mathrm{~F}$ & 66 & 102.07 & 26.05 & & & 23.5 & 31.5 & 48 \\
\hline $\mathrm{C}$ & 67 & & 54.15 & 80.2 & 0.32 & & & \\
\hline $6 \mathrm{~F}$ & 70 & 102.07 & 92.25 & & & 22 & 31.5 & 44 \\
\hline $\mathrm{C}$ & 71 & & 50.13 & 142.38 & 0.65 & & & \\
\hline $7 F$ & 74 & 102.07 & 64.07 & & & 20.5 & 31.5 & 42 \\
\hline $\mathrm{C}$ & 75 & & 85.49 & 149.56 & 0.43 & & & \\
\hline
\end{tabular}


Appendix D. (Continued).

\begin{tabular}{|c|c|c|c|c|c|c|c|c|}
\hline LogID & $\begin{array}{c}\text { MS } \\
\text { number }\end{array}$ & $\begin{array}{c}\text { Volume } \\
\text { total } \\
\text { sample } \\
\left(\mathrm{cm}^{3}\right)\end{array}$ & $\begin{array}{l}\text { Dry wt } \\
\text { fine and } \\
\text { coarse } \\
\text { fraction }(g)\end{array}$ & $\begin{array}{c}\text { Total dry } \\
\text { sample } \\
\text { wt } \\
\text { (g) }\end{array}$ & 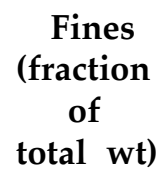 & $\begin{array}{l}\text { Minutes } \\
\text { east of } \\
165^{\circ} \mathrm{E} \\
X \text {-coord }\end{array}$ & $\begin{array}{c}\text { Minutes } \\
\text { north of } \\
11^{\circ} \mathrm{N} \\
Y \text {-coord }\end{array}$ & $\begin{array}{c}\text { Water } \\
\text { depth } \\
\text { (m) }\end{array}$ \\
\hline $8 \mathrm{~F}$ & 78 & 102.07 & 104.65 & & & 17.5 & 31.5 & 36 \\
\hline $\mathrm{C}$ & 79 & & 64.1 & 168.75 & 0.62 & & & \\
\hline $9 F$ & 82 & 102.07 & 42.76 & & & 16 & 32.8 & 32 \\
\hline $\mathrm{C}$ & 83 & & 85.37 & 128.13 & 0.33 & & & \\
\hline $10 \mathrm{~F}$ & 86 & 102.07 & 72.1 & & & 17.5 & 32.8 & 45 \\
\hline $\mathrm{C}$ & 87 & & 46.65 & 118.75 & 0.61 & & & \\
\hline $11 \mathrm{~F}$ & 90 & 102.07 & 89.65 & & & 20.5 & 32.8 & 54 \\
\hline C & 91 & & 49.82 & 139.47 & 0.64 & & & \\
\hline $12 \mathrm{~F}$ & 94 & 102.07 & 56.66 & & & 22 & 32.8 & 52 \\
\hline $\mathrm{C}$ & 95 & & 59.12 & 115.78 & 0.49 & & & \\
\hline $13 \mathrm{~F}$ & 98 & 102.07 & 95.57 & & & 23.5 & 32.8 & 57 \\
\hline C & 99 & & 26.83 & 122.4 & 0.78 & & & \\
\hline $14 \mathrm{~F}$ & 7602 & 102.07 & 21.47 & & & 25 & 32.8 & 54 \\
\hline $\mathrm{C}$ & 3 & & 55.69 & 77.16 & 0.28 & & & \\
\hline $15 \mathrm{~F}$ & 6 & 102.07 & 50.58 & & & 28 & 32.8 & 56 \\
\hline C & 7 & & 53.77 & 104.35 & 0.48 & & & \\
\hline $16 \mathrm{~F}$ & 10 & 102.07 & 24.9 & & & 28 & 34.3 & 59 \\
\hline $\mathrm{C}$ & 11 & & 52.95 & 77.85 & 0.32 & & & \\
\hline $17 \mathrm{~F}$ & 14 & 102.07 & 3.55 & & & 31 & 32.8 & 53 \\
\hline $\mathrm{C}$ & 15 & & 46.91 & 50.46 & 0.07 & & & \\
\hline $18 \mathrm{~F}$ & 18 & 102.07 & 19.55 & & & 31 & 34.3 & 47 \\
\hline $\mathrm{C}$ & 19 & & 46.78 & 66.33 & 0.29 & & & \\
\hline 6/16/79-7F & 34 & 102.07 & 41.9 & & & 17.5 & 40.2 & 45 \\
\hline C & 35 & & 54.35 & 96.25 & 0.44 & & & \\
\hline $9 \mathrm{~F}$ & 40 & 102.07 & 93.55 & & & 16 & 39 & 59 \\
\hline $\mathrm{C}$ & 41 & & 3.07 & 96.62 & 0.97 & & & \\
\hline $10 \mathrm{~F}$ & 44 & 102.07 & 102.68 & & & 14.5 & 39 & 43 \\
\hline C & 45 & & 3.92 & 106.6 & 0.96 & & & \\
\hline $11 \mathrm{~F}$ & 48 & 102.07 & 50.93 & & & 14.5 & 37.8 & 48 \\
\hline C & 49 & & 48.37 & 99.3 & 0.51 & & & \\
\hline $12 \mathrm{~F}$ & 52 & 102.07 & 28.35 & & & 17.5 & 37.7 & 57 \\
\hline C & 53 & & 65.26 & 93.61 & 0.30 & & & \\
\hline $13 \mathrm{~F}$ & 56 & 102.07 & 20.06 & & & 17.5 & 36 & 56 \\
\hline C & 57 & & 59.29 & 79.35 & 0.25 & & & \\
\hline $14 \mathrm{~F}$ & 60 & 102.07 & 15.07 & & & 20.5 & 36 & 55 \\
\hline $\mathrm{C}$ & 61 & & 37.08 & 52.15 & 0.29 & & & \\
\hline $15 \mathrm{~F}$ & 64 & 102.07 & 2.23 & & & 22 & 36 & 55 \\
\hline $\mathrm{C}$ & 65 & & 44.81 & 47.04 & 0.05 & & & \\
\hline $16 \mathrm{~F}$ & 68 & 102.07 & 6.21 & & & 23.5 & 36 & 58 \\
\hline
\end{tabular}


Appendix D. (Continued).

\begin{tabular}{|c|c|c|c|c|c|c|c|c|}
\hline $\log I D$ & $\begin{array}{c}\text { MS } \\
\text { number }\end{array}$ & $\begin{array}{c}\text { Volume } \\
\text { total } \\
\text { sample } \\
\left(\mathrm{cm}^{3}\right)\end{array}$ & $\begin{array}{l}\text { Dry wt } \\
\text { fine and } \\
\text { coarse } \\
\text { fraction }(g)\end{array}$ & $\begin{array}{l}\text { Total dry } \\
\text { sample } \\
\text { wt } \\
\text { (g) }\end{array}$ & 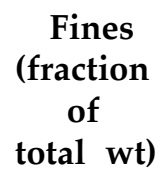 & $\begin{array}{l}\text { Minutes } \\
\text { east of } \\
165^{\circ} \mathrm{E} \\
X \text {-coord }\end{array}$ & $\begin{array}{c}\text { Minutes } \\
\text { north of } \\
11^{\circ} \mathrm{N} \\
Y \text {-coord }\end{array}$ & $\begin{array}{c}\text { Water } \\
\text { depth } \\
\text { (m) }\end{array}$ \\
\hline C & 69 & & 41.52 & 47.73 & 0.13 & & & \\
\hline $17 \mathrm{~F}$ & 72 & 102.07 & 4.6 & & & 25 & 36 & 59 \\
\hline C & 73 & & 40.37 & 44.97 & 0.10 & & & \\
\hline $18 \mathrm{~F}$ & 76 & 102.07 & 2.97 & & & 25 & 37.7 & 57 \\
\hline C & 77 & & 47 & 49.97 & 0.06 & & & \\
\hline $19 \mathrm{~F}$ & 80 & 102.07 & 43.66 & & & 23.5 & 37.7 & 49 \\
\hline C & 81 & & 41.69 & 85.35 & 0.51 & & & \\
\hline $20 \mathrm{~F}$ & 84 & 102.07 & 5.06 & & & 22 & 37.7 & 57 \\
\hline C & 85 & & 40.25 & 45.31 & 0.11 & & & \\
\hline $21 \mathrm{~F}$ & 88 & 102.07 & 5.72 & & & 20.5 & 37.7 & 58 \\
\hline $\mathrm{C}$ & 89 & & 45.24 & 50.96 & 0.11 & & & \\
\hline $22 \mathrm{~F}$ & 92 & 102.07 & 71.74 & & & 22 & 39 & 48 \\
\hline $\mathrm{C}$ & 93 & & 46.93 & 118.67 & 0.60 & & & \\
\hline $23 \mathrm{~F}$ & 96 & 102.07 & 73.94 & & & 23.5 & 39 & 50 \\
\hline $\mathrm{C}$ & 97 & & 33.57 & 107.51 & 0.69 & & & \\
\hline $6 / 17 / 79-2 F$ & 7702 & 102.07 & 54.26 & & & 29.5 & 30.1 & 29 \\
\hline $\mathrm{C}$ & 3 & & 75.45 & 129.71 & 0.42 & & & \\
\hline $3 F$ & 6 & 102.07 & 11.96 & & & 28 & 30.1 & 13 \\
\hline C & 7 & & 99.35 & 111.31 & 0.11 & & & \\
\hline $4 \mathrm{~F}$ & 10 & 102.07 & 29.06 & & & 26.6 & 30.3 & 19 \\
\hline $\mathrm{C}$ & 11 & & 84.55 & 113.61 & 0.26 & & & \\
\hline $5 \mathrm{~F}$ & 14 & 102.07 & 76.76 & & & 25.2 & 30.3 & 36 \\
\hline C & 15 & & 69.54 & 146.3 & 0.52 & & & \\
\hline $6 \mathrm{~F}$ & 18 & 102.07 & 95.84 & & & 23.5 & 30.5 & 31 \\
\hline$C$ & 19 & & 38.42 & 134.26 & 0.71 & & & \\
\hline $7 F$ & 22 & 102.07 & 26.6 & & & 22 & 30.1 & 24 \\
\hline$C$ & 23 & & 34.61 & 61.21 & 0.43 & & & \\
\hline $8 \mathrm{~F}$ & 26 & 102.07 & 18.09 & & & 20.5 & 30.4 & 34 \\
\hline C & 27 & & 31.79 & 49.88 & 0.36 & & & \\
\hline
\end{tabular}

$\mathrm{F}=$ fine; $\mathrm{C}=$ coarse fraction

All sediment subsampled to a depth of $4 \mathrm{~cm}$ from Shipek grab sampler.

Station locations provided by $X \& Y$ coordinates

a and b samples are replicate $0-4 \mathrm{~cm}$ surface sections at station from different Shipek grab samples. 
Appendix E

Concentration of ${ }^{241} \mathrm{Am}$ in Fine and Coarse Fractions in Surface $(0-2.5 \mathrm{~cm})$ Sections of Sediment Samples Collected from Bikini Lagoon During 10-11/1972 

Appendix E. Concentration of ${ }^{241} \mathrm{Am}$ in fine and coarse fractions in surface $(0-2.5 \mathrm{~cm})$ sections of sediment samples collected from Bikini lagoon during 10-11/1972.

\begin{tabular}{|c|c|c|c|c|c|c|c|c|c|}
\hline $\begin{array}{l}\text { Station } \\
\text { No. }\end{array}$ & $\begin{array}{l}\text { MSC } \\
\text { No. }\end{array}$ & $\begin{array}{c}\text { Fines } \\
\text { (fraction } \\
\text { of } \\
\text { total wt) }\end{array}$ & $\begin{array}{c}{ }^{241} \mathrm{Am} \\
\mathrm{Bqkg}^{-1} \\
\text { dry wt } \\
\text { fraction }\end{array}$ & $\begin{array}{l}\% \\
\text { error }\end{array}$ & $\begin{array}{l}{ }^{241} \mathrm{Am} \\
\mathrm{kBqm}^{-2} \\
\text { dry wt } \\
\text { fraction }\end{array}$ & $\begin{array}{l}\% \\
\text { error }\end{array}$ & $\begin{array}{c}{ }^{241} \mathrm{Am}^{\mathrm{dry} \mathrm{Bqkg}}{ }^{-1} \\
\text { total } \\
\text { sample }\end{array}$ & $\begin{array}{l}{ }^{241} \mathrm{Am} \\
\text { dry kBqm } \\
\text { total } \\
\text { sample }\end{array}$ & $\begin{array}{c}2 \\
\quad \% \\
\text { error }\end{array}$ \\
\hline B3 & $44 \mathrm{f}$ & & 530 & 3 & 14.9 & 3 & 461 & 18.0 & 3 \\
\hline B3 & $44 \mathrm{c}$ & 0.72 & 285 & 3 & 3.1 & 3 & & & \\
\hline B19 & $54 \mathrm{f}$ & & 3926 & 1 & 16.0 & 1 & 1947 & 34.7 & 0 \\
\hline B19 & $54 \mathrm{c}$ & 0.23 & 1363 & 1 & 18.8 & 1 & & & \\
\hline B18 & $55 \mathrm{f}$ & & 3815 & 1 & 38.8 & 1 & 2490 & 67.9 & 0 \\
\hline B18 & $55 c$ & 0.37 & 1704 & 1 & 29.2 & 1 & & & \\
\hline B21 & $56 f$ & & 907 & 2 & 22.5 & 2 & 768 & 26.1 & 2 \\
\hline B21 & $56 c$ & 0.73 & 389 & 3 & 3.5 & 3 & & & \\
\hline B22 & $57 f$ & & 178 & 2 & 0.5 & 2 & 1020 & 14.4 & 0 \\
\hline B22 & $57 \mathrm{c}$ & 0.21 & 1244 & 1 & 13.8 & 1 & & & \\
\hline B24 & $58 \mathrm{f}$ & & 1959 & 3 & 3.2 & 3 & 1015 & 15.4 & 1 \\
\hline B24 & $59 c$ & 0.11 & 900 & 1 & 12.2 & 1 & & & \\
\hline C11 & $66 f$ & & 208 & 5 & 3.0 & 5 & 176 & 5.2 & 4 \\
\hline C11 & $66 c$ & 0.49 & 145 & 6 & 2.2 & 6 & & & \\
\hline C8 & $68 \mathrm{f}$ & & 1252 & 1 & 33.6 & 1 & 1218 & 34.9 & 0 \\
\hline C8 & $68 c$ & 0.94 & 726 & 5 & 1.3 & 5 & & & \\
\hline B2 & $69 \mathrm{f}$ & & 2570 & 1 & 69.8 & 1 & 2504 & 73.7 & 0 \\
\hline B2 & $69 c$ & 0.92 & 1707 & 2 & 3.9 & 2 & & & \\
\hline B4 & $45 \mathrm{f}$ & & 109 & 6 & 0.5 & 6 & 67 & 2.2 & 3 \\
\hline B4 & $45 c$ & 0.14 & 60 & 3 & 1.7 & 3 & & & \\
\hline B6 & $46 f$ & & 45 & 6 & 1.1 & 6 & 41 & 1.5 & 6 \\
\hline B6 & $46 c$ & 0.67 & 34 & 16 & 0.4 & 16 & & & \\
\hline B7 & $47 f$ & & 90 & 4 & 1.8 & 4 & 81 & 2.7 & 4 \\
\hline B7 & $47 \mathrm{c}$ & 0.58 & 67 & 7 & 1.0 & 7 & & & \\
\hline B8 & $48 \mathrm{f}$ & & 47 & 7 & 1.0 & 7 & 40 & 1.5 & 5 \\
\hline B8 & $48 \mathrm{c}$ & 0.54 & 31 & 8 & 0.5 & 8 & & & \\
\hline B10 & $49 \mathrm{f}$ & & 4 & 100 & 0.0 & 100 & 3 & 0.0 & 87 \\
\hline B10 & $49 \mathrm{c}$ & 0.12 & 3 & 100 & 0.0 & 100 & & & \\
\hline B10 & $50 \mathrm{f}$ & & 4 & 100 & 0.0 & 100 & 3 & 0.1 & 77 \\
\hline B10 & $50 c$ & 0.24 & 3 & 100 & 0.0 & 100 & & & \\
\hline B11 & $51 \mathrm{f}$ & & 31 & 8 & 0.5 & 8 & 27 & 0.9 & 6 \\
\hline B11 & $51 \mathrm{c}$ & 0.47 & 23 & 9 & 0.4 & 9 & & & \\
\hline B11 & $52 \mathrm{f}$ & & 25 & 10 & 0.4 & 10 & 30 & 1.0 & 7 \\
\hline B11 & $52 c$ & 0.46 & 34 & 9 & 0.6 & 9 & & & \\
\hline B16 & $53 \mathrm{f}$ & & 85 & 4 & 0.7 & 4 & 73 & 1.6 & 3 \\
\hline B16 & $53 c$ & 0.36 & 66 & 5 & 0.9 & 5 & & & \\
\hline B23 & $58 \mathrm{f}$ & & 110 & 3 & 2.1 & 3 & 103 & 3.6 & 2 \\
\hline B23 & $58 \mathrm{c}$ & 0.54 & 96 & 3 & 1.5 & 3 & & & \\
\hline B25 & $60 \mathrm{f}$ & & 552 & 2 & 4.0 & 2 & 278 & 8.2 & 1 \\
\hline
\end{tabular}


Appendix E. (Continued).

\begin{tabular}{|c|c|c|c|c|c|c|c|c|c|}
\hline $\begin{array}{l}\text { Station } \\
\text { No. }\end{array}$ & $\begin{array}{l}\text { MSC } \\
\text { No. }\end{array}$ & $\begin{array}{c}\begin{array}{c}\text { Fines } \\
\text { (fraction }\end{array} \\
\text { of } \\
\text { total wt) }\end{array}$ & $\begin{array}{l}{ }^{241} \mathrm{Am} \\
\mathrm{Bqkg}^{-1} \\
\text { dry wt } \\
\text { fraction }\end{array}$ & $\begin{array}{l}\% \\
\text { error }\end{array}$ & $\begin{array}{l}{ }^{241} \mathrm{Am} \\
\mathrm{kBqm}^{-2} \\
\text { dry wt } \\
\text { fraction }\end{array}$ & $\begin{array}{l}\% \\
\text { error }\end{array}$ & $\begin{array}{c}{ }^{241} \mathrm{Am}^{-1} \\
\text { dry Bqkg } \\
\text { total } \\
\text { sample }\end{array}$ & $\begin{array}{l}{ }^{241} \mathrm{Am} \\
\text { dry } \mathrm{kBqm}^{-2} \\
\text { total } \\
\text { sample }\end{array}$ & $\begin{array}{c}\% \\
\text { error }\end{array}$ \\
\hline B25 & $60 c$ & 0.24 & 190 & 2 & 4.3 & 2 & & & \\
\hline B26 & $61 \mathrm{f}$ & & 611 & 4 & 0.5 & 4 & 357 & 4.2 & 2 \\
\hline B26 & 61c & 0.06 & 340 & 2 & 3.8 & 2 & & & \\
\hline B15 & $64 \mathrm{f}$ & & 60 & 6 & 0.9 & 6 & 64 & 1.8 & 5 \\
\hline B15 & $64 c$ & 0.51 & 68 & 7 & 0.9 & 7 & & & \\
\hline C6 & $29 \mathrm{f}$ & & 485 & 2 & 2.6 & 2 & 930 & 28.3 & 0 \\
\hline C6 & $29 c$ & 0.82 & 1026 & 1 & 25.6 & 1 & & & \\
\hline
\end{tabular}




\section{Appendix F}

Concentration of ${ }^{241} \mathrm{Am}$ in Fractions from Core Sections of Sediment from Bikini, 10-11/1972 

Appendix F. Concentration of ${ }^{241} \mathrm{Am}$ in fractions from core sections of sediment from Bikini, 10-11/1972.

\begin{tabular}{|c|c|c|c|c|c|c|c|c|c|}
\hline $\begin{array}{l}\text { Station } \\
\text { number } \\
\text { \& date } \\
\text { collected }\end{array}$ & $\begin{array}{l}\text { Depth } \\
\text { increment } \\
\text { (cm) }\end{array}$ & $\begin{array}{l}\text { Dry wt } \\
\text { fine } \\
t \text { and coarse } \\
\text { fraction }(g)\end{array}$ & $\begin{array}{l}{ }^{241} \mathrm{Am} \\
\text { dry wt } \\
\mathrm{Bqkg}^{-1} \\
\text { fraction }\end{array}$ & $\begin{array}{c}\% \\
\text { error }\end{array}$ & $\begin{array}{l}{ }^{241} \mathrm{Am} \\
\text { dry wt } \\
\mathrm{kBqm}^{-2} \\
\text { fraction }\end{array}$ & $\begin{array}{l}\% \\
\text { error }\end{array}$ & $\begin{array}{c}{ }^{241} \mathrm{Am} \\
\text { dry } \\
\text { Bqkg }^{-1} \\
\text { total }\end{array}$ & $\begin{array}{l}{ }^{241} \mathrm{Am} \\
\text { dry } \\
\mathrm{kBqm}^{-2} \\
\text { total }\end{array}$ & $\begin{array}{l}\% \\
\text { error }\end{array}$ \\
\hline B-3 & $0-5 f$ & 111.1 & 310 & 2 & 9.5 & 2 & 284 & 19.0 & 2 \\
\hline \multirow[t]{13}{*}{$11 / 8 / 72$} & $0-5 c$ & 132 & 263 & 3 & 9.6 & 3 & & & \\
\hline & 5-10f & 48.9 & 411 & 2 & 5.5 & 2 & 257 & 11.6 & 2 \\
\hline & $5-10 c$ & 115 & 191 & 3 & 6.1 & 3 & & & \\
\hline & $10-15 f$ & 52.7 & 752 & 2 & 10.9 & 2 & 385 & 18.0 & 2 \\
\hline & $10-15 c$ & 116.5 & 220 & 3 & 7.0 & 3 & & & \\
\hline & 15-20f & 50.4 & 581 & 2 & 8.1 & 2 & 252 & 10.6 & 2 \\
\hline & $15-20 c$ & 102.2 & 89 & 5 & 2.5 & 5 & & & \\
\hline & $20-25 f$ & 53.4 & 307 & 3 & 4.5 & 3 & 123 & 5.5 & 3 \\
\hline & $20-25 c$ & 108.5 & 33 & 10 & 1.0 & 10 & & & \\
\hline & 25-30f & 56.3 & 64 & 6 & 1.0 & 6 & 23 & 1.1 & 12 \\
\hline & $25-30 c$ & 123.3 & 4 & 100 & 0.1 & 100 & & & \\
\hline & $30-35 f$ & 47.8 & 59 & 6 & 0.8 & 6 & 19 & 0.9 & 15 \\
\hline & $30-35 c$ & 122.9 & 4 & 100 & 0.1 & 100 & & & \\
\hline B-4 & $0-3$ & 88.6 & 86 & 5 & 2.1 & 5 & 185 & 2.1 & 5 \\
\hline \multirow[t]{2}{*}{$11 / 8 / 72$} & $3-6$ & 123.3 & 87 & 5 & 3.0 & 5 & 185 & 3.0 & 5 \\
\hline & $6-7$ & 30.3 & 86 & 7 & 0.7 & 7 & 259 & 0.7 & 7 \\
\hline B-16 & $0-3$ & 119.9 & 74 & 5 & 2.5 & 5 & 185 & 2.5 & 5 \\
\hline \multirow[t]{4}{*}{$11 / 4 / 72$} & $3-6$ & 97.3 & 78 & 5 & 2.1 & 5 & 185 & 2.1 & 5 \\
\hline & $6-9$ & 97.7 & 83 & 5 & 2.2 & 5 & 185 & 2.2 & 5 \\
\hline & 9-12 & 97.2 & 75 & 5 & 2.0 & 5 & 185 & 2.0 & 5 \\
\hline & $12-15$ & 97.2 & 80 & 5 & 2.2 & 5 & 185 & 2.2 & 5 \\
\hline B-18 & $0-3$ & 122.1 & 2722 & 1 & 91.5 & 1 & 37 & 91.5 & 1 \\
\hline \multirow[t]{3}{*}{$11 / 4 / 72$} & $3-6$ & 109.1 & 3041 & 1 & 91.3 & 1 & 37 & 91.3 & 1 \\
\hline & $6-9$ & 121.2 & 3619 & 1 & 120.7 & 1 & 37 & 120.7 & 1 \\
\hline & 9-10.5 & 61.2 & 4148 & 1 & 69.9 & 1 & 37 & 69.9 & 1 \\
\hline B-20 & $0-5 f$ & 180.1 & 2341 & 2 & 116.1 & 2 & 2223 & 117.3 & 2 \\
\hline \multirow[t]{5}{*}{$11 / 8 / 72$} & $0-5 c$ & 11.56 & 396 & 5 & 1.3 & 5 & & & \\
\hline & $5-10 f$ & 184.2 & 1756 & 2 & 89.0 & 2 & 1680 & 89.6 & 2 \\
\hline & $5-10 c$ & 9.48 & 210 & 7 & 0.5 & 7 & & & \\
\hline & 10-15f & 96.7 & 271 & 2 & 7.2 & 2 & 158 & 7.2 & 2 \\
\hline & $10-15 c$ & 69.3 & 0 & 100 & 0.0 & 100 & & & \\
\hline
\end{tabular}


Appendix F. (Continued).

\begin{tabular}{|c|c|c|c|c|c|c|c|c|c|}
\hline $\begin{array}{l}\text { Station } \\
\text { number } \\
\text { \& date } \\
\text { collected }\end{array}$ & $\begin{array}{c}\text { Depth } \\
\text { incremen } \\
\text { (cm) }\end{array}$ & $\begin{array}{l}\text { Dry wt } \\
\text { fine } \\
\text { th and coarse } \\
\text { fraction }(g)\end{array}$ & $\begin{array}{l}{ }^{241} \mathrm{Am} \\
\text { dry } w t \\
\text { Bqkg-1 } \\
\text { fraction }\end{array}$ & $\begin{array}{c}\% \\
\text { error }\end{array}$ & $\begin{array}{c}{ }^{241} \mathrm{Am} \\
\text { dry } w t \\
\mathrm{kBqm}^{-2} \\
\text { fraction }\end{array}$ & $\begin{array}{l}\% \\
\text { error }\end{array}$ & $\begin{array}{c}{ }^{241} \mathrm{Am} \\
\text { dry } \\
\text { Bqkg-1 }^{-1} \\
\text { total }\end{array}$ & $\begin{array}{l}{ }^{241} \mathrm{Am} \\
\text { dry } \\
\mathrm{kBqm}^{-2} \\
\text { total }\end{array}$ & $\begin{array}{l}\% \\
\text { error }\end{array}$ \\
\hline B-25 & $0-3$ & 70.9 & 648 & 1 & 12.6 & 1 & 37 & 12.6 & 1 \\
\hline \multirow[t]{5}{*}{$11 / 5 / 72$} & $3-6$ & 83.3 & 1644 & 1 & 62.8 & 1 & 37 & 62.8 & 1 \\
\hline & $6-9$ & 90.7 & 1485 & 1 & 61.8 & 1 & 37 & 61.8 & 1 \\
\hline & $9-12$ & 96.7 & 267 & 2 & 11.8 & 2 & 74 & 11.8 & 2 \\
\hline & $12-15$ & 100.1 & 159 & 4 & 7.3 & 4 & 148 & 7.3 & 4 \\
\hline & $15-18$ & 98.4 & 25 & 11 & 1.1 & 11 & 407 & 1.1 & 11 \\
\hline$C-2$ & $0-6$ & 86 & 1541 & 1 & 36.5 & 1 & 1541 & 36.5 & 1 \\
\hline $11 / 13 / 72$ & $6-12$ & 154.5 & 1567 & 1 & 66.6 & 1 & 1567 & 66.6 & 1 \\
\hline Bravo & $12-18$ & 187.8 & 1622 & 1 & 83.8 & 1 & 1622 & 83.8 & 1 \\
\hline \multirow[t]{17}{*}{ Crater } & $18-24$ & 183 & 1667 & 1 & 83.9 & 1 & 1667 & 83.9 & 1 \\
\hline & $24-30$ & 177.4 & 1544 & 1 & 75.4 & 1 & 1544 & 75.4 & 1 \\
\hline & $30-36$ & 192 & 1570 & 1 & 83.0 & 1 & 1570 & 83.0 & 1 \\
\hline & $36-42$ & 187.3 & 1619 & 1 & 83.4 & 1 & 1619 & 83.4 & 1 \\
\hline & $42-48$ & 195 & 1619 & 1 & 86.9 & 1 & 1619 & 86.9 & 1 \\
\hline & $48-54$ & 182 & 1796 & 1 & 90.0 & 1 & 1796 & 90.0 & 1 \\
\hline & $54-60$ & 229.2 & 1533 & 1 & 96.7 & 1 & 1533 & 96.7 & 1 \\
\hline & $60-66$ & 201 & 1563 & 1 & 86.5 & 1 & 1563 & 86.5 & 1 \\
\hline & $66-72$ & 194.8 & 1622 & 1 & 87.0 & 1 & 1622 & 87.0 & 1 \\
\hline & $72-78$ & 191.4 & 1563 & 1 & 82.3 & 1 & 1563 & 82.3 & 1 \\
\hline & $78-84$ & 198.8 & 1648 & 1 & 90.2 & 1 & 1648 & 90.2 & 1 \\
\hline & $84-90$ & 209.8 & 1711 & 1 & 98.8 & 1 & 1711 & 98.8 & 1 \\
\hline & $90-96$ & 215 & 1644 & 1 & 97.3 & 1 & 1644 & 97.3 & 1 \\
\hline & 96-102 & 217 & 1585 & 1 & 94.7 & 1 & 1585 & 94.7 & 1 \\
\hline & $102-108$ & 210 & 1670 & 1 & 96.5 & 1 & 1670 & 96.5 & 1 \\
\hline & 108-114 & 202 & 1841 & 1 & 102.3 & 1 & 1841 & 102.3 & 1 \\
\hline & $114-120$ & 228 & 1978 & 1 & 124.1 & 1 & 1978 & 124.1 & 1 \\
\hline$C-3$ & $0-6$ & 213 & 1356 & 1 & 79.5 & 1 & 1356 & 79.5 & 1 \\
\hline $11 / 13 / 72$ & $6-12$ & 196.1 & 1130 & 1 & 61.0 & 1 & 1130 & 61.0 & 1 \\
\hline Bravo & $12-18$ & 236.2 & 548 & 1 & 35.6 & 1 & 548 & 35.6 & 1 \\
\hline \multirow[t]{5}{*}{ Crater } & $18-24$ & 237.2 & 507 & 1 & 33.1 & 1 & 507 & 33.1 & 1 \\
\hline & $24-30$ & 240.1 & 511 & 1 & 33.8 & 1 & 511 & 33.8 & 1 \\
\hline & $30-36$ & 234.6 & 526 & 1 & 34.0 & 1 & 526 & 34.0 & 1 \\
\hline & $36-42$ & 231.8 & 611 & 1 & 39.0 & 1 & 611 & 39.0 & 1 \\
\hline & $42-48$ & 237.7 & 967 & 1 & 63.2 & 1 & 967 & 63.2 & 1 \\
\hline
\end{tabular}


Appendix F. (Continued).

\begin{tabular}{|c|c|c|c|c|c|c|c|c|c|}
\hline $\begin{array}{l}\text { Station } \\
\text { number } \\
\text { \& date } \\
\text { collected }\end{array}$ & $\begin{array}{l}\text { Depth } \\
\text { increment } \\
\text { (cm) }\end{array}$ & $\begin{array}{l}\text { Dry wt } \\
\text { fine } \\
t \text { and coarse } \\
\text { fraction }(g)\end{array}$ & $\begin{array}{l}{ }^{241} \mathrm{Am} \\
\text { dry wt } \\
\mathrm{Bqkg}^{-1} \\
\text { fraction }\end{array}$ & $\begin{array}{c}\% \\
\text { error }\end{array}$ & $\begin{array}{l}{ }^{241} \mathrm{Am} \\
\text { dry wt } \\
\mathrm{kBqm}^{-2} \\
\text { fraction }\end{array}$ & $\begin{array}{l}\% \\
\text { error }\end{array}$ & $\begin{array}{c}{ }^{241} \mathrm{Am} \\
\text { dry } \\
\text { Bqkg }^{-1} \\
\text { total }\end{array}$ & $\begin{array}{l}{ }^{241} \mathrm{Am} \\
\text { dry } \\
\mathrm{kBqm}^{-2} \\
\text { total }\end{array}$ & $\begin{array}{l}\% \\
\text { error }\end{array}$ \\
\hline$C-1$ & $0-6$ & 249.5 & 1319 & 1 & 90.5 & 1 & 1319 & 90.5 & 1 \\
\hline $11 / 13 / 72$ & $6-12$ & 268.1 & 1304 & 1 & 96.2 & 1 & 1304 & 96.2 & 1 \\
\hline Bravo & $12-18$ & 257.4 & 1448 & 1 & 102.6 & 1 & 1448 & 102.6 & 1 \\
\hline \multirow[t]{4}{*}{ Crater } & $18-24$ & 250 & 1359 & 1 & 93.5 & 1 & 1359 & 93.5 & 1 \\
\hline & $24-30$ & 264.2 & 1393 & 1 & 101.3 & 1 & 1393 & 101.3 & 1 \\
\hline & $30-36$ & 257.4 & 1433 & 1 & 101.5 & 1 & 1433 & 101.5 & 1 \\
\hline & $36-41$ & 200.5 & 1026 & 1 & 67.8 & 1 & 1026 & 67.8 & 1 \\
\hline C-11 & $0-6$ & 281 & 422 & 3 & 32.7 & 3 & 422 & 32.7 & 3 \\
\hline $11 / 14 / 72$ & $6-12$ & 259.1 & 193 & 7 & 13.7 & 7 & 193 & 13.7 & 7 \\
\hline Zuni & $12-18$ & 257 & 230 & 5 & 16.2 & 5 & 230 & 16.2 & 5 \\
\hline \multirow[t]{2}{*}{ Crater } & $18-24$ & 255.6 & 104 & 9 & 7.3 & 9 & 104 & 7.3 & 9 \\
\hline & $24-31$ & 273.5 & 73 & 6 & 6.5 & 6 & 73 & 6.5 & 6 \\
\hline$C-8$ & $0-6$ & 190.5 & 1070 & 2 & 56.1 & 2 & 1070 & 56.1 & 2 \\
\hline $11 / 14 / 72$ & $6-12$ & 237.2 & 1007 & 2 & 65.8 & 2 & 1007 & 65.8 & 2 \\
\hline Tewa & $12-17.5$ & 231 & 1148 & 2 & 72.9 & 2 & 1148 & 72.9 & 2 \\
\hline \multicolumn{10}{|l|}{ Crater } \\
\hline B-15 & $0-2.5 f$ & 44.4 & 82 & 3 & 1.0 & 3 & 76 & 1.8 & 3 \\
\hline \multirow[t]{9}{*}{$10 / 31 / 72$} & $0-2.5 \mathrm{c}$ & 39.7 & 69 & 7 & 0.8 & 7 & & & \\
\hline & $2.5-5.0 \mathrm{f}$ & 68.8 & 62 & 3 & 1.2 & 3 & 56 & 1.9 & 3 \\
\hline & $2.5-5.0 \mathrm{c}$ & 57.2 & 49 & 7 & 0.8 & 7 & & & \\
\hline & $5.0-7.5 \mathrm{f}$ & 50.5 & 65 & 4 & 0.9 & 4 & 51 & 1.8 & 4 \\
\hline & $5.0-7.5 \mathrm{c}$ & 79.7 & 43 & 7 & 0.9 & 7 & & & \\
\hline & 7.5-10.0f & 42.7 & 70 & 5 & 0.8 & 5 & 53 & 1.5 & 4 \\
\hline & $7.5-10.0 \mathrm{c}$ & 62 & 41 & 7 & 0.7 & 7 & & & \\
\hline & $10.0-12.5 f$ & 29.4 & 86 & 4 & 0.7 & 4 & 47 & 1.3 & 4 \\
\hline & $10.0-12.5 c$ & 70.6 & 31 & 7 & 0.6 & 7 & & & \\
\hline
\end{tabular}

All cores: diameter $=6.8 \mathrm{~cm}$; area $=36.32 \mathrm{~cm}^{2}$

$\mathrm{f}=$ fine; $\mathrm{c}=$ coarse fractions 

Appendix G

Concentration of ${ }^{241} \mathrm{Am}$ and ${ }^{241} \mathrm{Am} /{ }^{239+240} \mathrm{Pu}$ Concentration Ratios in Fine and Coarse Fractions from Surface (0-2 cm) Sections of Sediment Samples Collected from Bikini Lagoon During 4-6/1979 

Appendix G . Concentration of ${ }^{241} \mathrm{Am}$ and ${ }^{241} \mathrm{Am} /{ }^{239+240} \mathrm{Pu}$ concentration ratios in fine and coarse fractions from surface $(0-2 \mathrm{~cm})$ sections of sediment samples collected from Bikini lagoon during 4-6/1979.

\begin{tabular}{|c|c|c|c|c|c|c|c|c|c|c|}
\hline $\log$ ID & $\begin{array}{l}\text { MS } \\
\text { No. }\end{array}$ & $\begin{array}{c}\text { Fines } \\
\text { (fraction } \\
\text { of } \\
\text { total wt) }\end{array}$ & $\begin{array}{l}{ }^{241} \mathrm{Am} \\
\text { dry wt } \\
\mathrm{Bqkg}^{-1} \\
\text { fraction }\end{array}$ & $\begin{array}{l}\% \\
\text { error }\end{array}$ & $\begin{array}{l}{ }^{241} \mathrm{Am} \\
\text { dry wt } \\
\mathrm{kBqm}^{-2} \\
\text { fraction }\end{array}$ & $\begin{array}{l}\% \\
\text { error }\end{array}$ & $\begin{array}{l}{ }^{241} \text { Am } \\
\text { dry } \\
\text { Bqkg-1 } \\
\text { total } \\
\text { sample }\end{array}$ & $\begin{array}{c}{ }^{241} \mathrm{Am} \\
\text { dry } \\
\mathrm{kBqm}^{-2} \\
\text { total } \\
\text { sample }\end{array}$ & $\begin{array}{l}\% \\
\text { error }\end{array}$ & $\begin{array}{c}{ }^{241} \mathrm{Am} / \\
{ }^{239+240} \mathrm{Pu}\end{array}$ \\
\hline 4/22/79-1F & 7400 & & 38 & 9 & 0.71 & 9 & 63 & 1.6 & 6 & \\
\hline $\mathrm{C}$ & 7401 & 0.75 & 138 & 8 & 0.86 & 8 & & & & \\
\hline $2 \mathrm{~F}$ & 2 & & 49 & 26 & 0.21 & 26 & 46 & 1.2 & 8 & 0.88 \\
\hline $\mathrm{C}$ & 3 & 0.18 & 46 & 8 & 0.94 & 8 & & & & \\
\hline $3 F$ & 4 & & 95 & 6 & 1.02 & 6 & 103 & 2.4 & 4 & \\
\hline $\mathrm{C}$ & 5 & 0.47 & 111 & 6 & 1.35 & 6 & & & & \\
\hline $4 \mathrm{~F}$ & 8 & & 57 & 9 & 0.64 & 9 & 55 & 1.5 & 5 & \\
\hline $\mathrm{C}$ & 9 & 0.42 & 54 & 6 & 0.82 & 6 & & & & \\
\hline $5 \mathrm{~F}$ & 12 & & 113 & 10 & 0.64 & 10 & 119 & 2.2 & 6 & \\
\hline $\mathrm{C}$ & 13 & 0.30 & 122 & 7 & 1.60 & 7 & & & & \\
\hline $6 \mathrm{~F}$ & 16 & & 45 & 6 & 1.11 & 6 & 60 & 1.6 & 4 & 0.58 \\
\hline $\mathrm{C}$ & 17 & 0.89 & 180 & 5 & 0.53 & 5 & & & & \\
\hline $7 F$ & 18 & & 299 & 11 & 0.71 & 11 & 164 & 2.0 & 7 & \\
\hline $\mathrm{C}$ & 19 & 0.19 & 132 & 9 & 1.31 & 9 & & & & \\
\hline $9 \mathrm{~F}$ & 22 & & 159 & 8 & 1.35 & 8 & 142 & 3.5 & 5 & 0.61 \\
\hline $\mathrm{C}$ & 23 & 0.34 & 133 & 6 & 2.15 & 6 & & & & \\
\hline $10 \mathrm{~F}$ & 24 & & 265 & 8 & 0.91 & 8 & 174 & 3.5 & 5 & \\
\hline $\mathrm{C}$ & 25 & 0.17 & 155 & 6 & 2.60 & 6 & & & & \\
\hline $11 \mathrm{~F}$ & 28 & & 597 & 15 & 0.38 & 15 & 615 & 6.1 & 6 & \\
\hline $\mathrm{C}$ & 29 & 0.06 & 617 & 6 & 5.69 & 6 & & & & \\
\hline $12 \mathrm{~F}$ & 32 & & 454 & 14 & 0.35 & 14 & 454 & 4.7 & 5 & \\
\hline C & 33 & 0.08 & 454 & 5 & 4.31 & 5 & & & & \\
\hline $13 \mathrm{~F}$ & 36 & & 623 & 12 & 0.84 & 12 & 433 & 5.7 & 5 & \\
\hline C & 37 & 0.10 & 411 & 6 & 4.90 & 6 & & & & \\
\hline $14 \mathrm{~F}$ & 40 & & 179 & 6 & 2.83 & 6 & 163 & 4.4 & 5 & 0.31 \\
\hline $\mathrm{C}$ & 41 & 0.59 & 141 & 11 & 1.55 & 11 & & & & \\
\hline $4 / 23 / 79-1 F$ & 42 & & 157 & 7 & 1.54 & 7 & 142 & 3.7 & 5 & \\
\hline $\mathrm{C}$ & 43 & 0.38 & 133 & 6 & 2.13 & 6 & & & & \\
\hline $2 \mathrm{~F}$ & 46 & & 419 & 6 & 1.65 & 6 & 280 & 4.8 & 5 & 0.62 \\
\hline $\mathrm{C}$ & 47 & 0.23 & 239 & 7 & 3.12 & 7 & & & & \\
\hline $3 F$ & 50 & & 73 & 8 & 0.87 & 8 & 63 & 1.9 & 5 & \\
\hline $\mathrm{C}$ & 51 & 0.41 & 57 & 7 & 0.98 & 7 & & & & \\
\hline $4 / 24 / 79-1 F$ & 54 & & 61 & 6 & 0.68 & 6 & 56 & 1.5 & 5 & 0.55 \\
\hline $\mathrm{C}$ & 55 & 0.42 & 53 & 7 & 0.84 & 7 & & & & \\
\hline $2 \mathrm{Fa}$ & 58 & & 396 & 9 & 0.71 & 9 & 246 & 3.5 & 5 & \\
\hline C & 59 & 0.13 & 225 & 6 & 2.82 & 6 & & & & \\
\hline
\end{tabular}


Appendix G . (Continued).

\begin{tabular}{|c|c|c|c|c|c|c|c|c|c|c|}
\hline $\log$ ID & $\begin{array}{l}\text { MS } \\
\text { No. }\end{array}$ & $\begin{array}{c}\text { Fines } \\
\text { (fraction } \\
\text { of } \\
\text { total wt) }\end{array}$ & $\begin{array}{l}{ }^{241} \mathrm{Am} \\
\text { dry wt } \\
\mathrm{Bqkg}^{-1} \\
\text { fraction }\end{array}$ & $\begin{array}{l}\% \\
\text { error }\end{array}$ & $\begin{array}{l}{ }^{241} \mathrm{Am} \\
\text { dry } w \mathrm{t} \\
\mathrm{kBqm}^{-2} \\
\text { fraction }\end{array}$ & $\begin{array}{l}\% \\
\text { error }\end{array}$ & $\begin{array}{l}{ }^{241} \mathrm{Am} \\
\text { dry } \\
\text { Bqkg-1 } \\
\text { total } \\
\text { sample }\end{array}$ & $\begin{array}{c}{ }^{241} \mathrm{Am} \\
\text { dry } \\
\mathrm{kBqm}^{-2} \\
\text { total } \\
\text { sample }\end{array}$ & $\begin{array}{l}\% \\
\text { error }\end{array}$ & $\begin{array}{c}{ }^{241} \mathrm{Am} / \\
{ }^{239+240} \mathrm{Pu}\end{array}$ \\
\hline $2 \mathrm{Fb}$ & 62 & & 736 & 5 & 3.36 & 5 & 479 & 8.2 & 5 & \\
\hline C & 63 & 0.27 & 385 & 7 & 4.82 & 7 & & & & \\
\hline $3 \mathrm{Fa}$ & 66 & & 620 & 11 & 0.39 & 11 & 281 & 2.8 & 7 & \\
\hline C & 67 & 0.06 & 259 & 8 & 2.44 & 8 & & & & \\
\hline $3 \mathrm{Fb}$ & 70 & & 629 & 21 & 0.22 & 21 & 572 & 5.6 & 7 & \\
\hline C & 71 & 0.04 & 570 & 7 & 5.41 & 7 & & & & \\
\hline $4 \mathrm{~F}$ & 74 & & 291 & 13 & 1.29 & 13 & 295 & 6.0 & 5 & \\
\hline C & 75 & 0.22 & 296 & 6 & 4.75 & 6 & & & & \\
\hline $5 \mathrm{~F}$ & 78 & & 822 & 15 & 0.27 & 15 & 503 & 5.4 & 6 & \\
\hline C & 79 & 0.03 & 493 & 6 & 5.11 & 6 & & & & \\
\hline $6 \mathrm{~F}$ & 82 & & 1329 & 9 & 1.85 & 9 & 638 & 6.9 & 5 & \\
\hline C & 83 & 0.13 & 536 & 6 & 5.08 & 6 & & & & \\
\hline $7 F$ & 86 & & 1149 & 6 & 1.40 & 6 & 533 & 6.0 & 5 & \\
\hline C & 87 & 0.11 & 458 & 6 & 4.63 & 6 & & & & \\
\hline $8 \mathrm{~F}$ & 90 & & 240 & 9 & 3.34 & 9 & 179 & 5.0 & 6 & \\
\hline C & 91 & 0.50 & 117 & 5 & 1.61 & 5 & & & & \\
\hline $9 \mathrm{Fb}$ & 94 & & 548 & 6 & 9.50 & 6 & 452 & 12.3 & 5 & 0.65 \\
\hline C & 95 & 0.64 & 282 & 5 & 2.77 & 5 & & & & \\
\hline $10 \mathrm{~F}$ & 96 & & 304 & 10 & 7.48 & 10 & 284 & 9.1 & 8 & \\
\hline C & 97 & 0.77 & 220 & 6 & 1.66 & 6 & & & & \\
\hline $11 \mathrm{~F}$ & 7500 & & 323 & 75 & 6.21 & 75 & 288 & 8.5 & 55 & \\
\hline C & 1 & 0.65 & 224 & 8 & 2.33 & 8 & & & & \\
\hline $12 \mathrm{~F}$ & 4 & & 812 & 11 & 17.29 & 11 & 786 & 22.5 & 9 & 0.72 \\
\hline C & 5 & 0.74 & 711 & 5 & 5.19 & 5 & & & & \\
\hline $13 \mathrm{~F}$ & 8 & & 1024 & 6 & 4.64 & 6 & 441 & 8.4 & 4 & \\
\hline C & 9 & 0.24 & 258 & 6 & 3.73 & 6 & & & & \\
\hline $14 \mathrm{~F}$ & 10 & & 481 & 68 & 5.22 & 68 & 382 & 9.4 & 38 & \\
\hline C & 11 & 0.44 & 304 & 9 & 4.20 & 9 & & & & \\
\hline $15 \mathrm{~F}$ & 12 & & 7970 & 9 & 157.38 & 9 & 6555 & 165.0 & 9 & \\
\hline C & 13 & 0.78 & 1407 & 16 & 7.64 & 16 & & & & \\
\hline $17 \mathrm{~F}$ & 20 & & 2955 & 10 & 72.78 & 10 & 2955 & 73.1 & 10 & 0.90 \\
\hline C & 21 & 1.00 & 3007 & 7 & 0.36 & 7 & & & & \\
\hline $4 / 25 / 79-1 F$ & 24 & & 5041 & 9 & 48.31 & 9 & 3359 & 62.2 & 8 & \\
\hline C & 25 & 0.52 & 1556 & 14 & 13.91 & 14 & & & & \\
\hline $2 \mathrm{~F}$ & 28 & & 2237 & 5 & 15.75 & 5 & 1310 & 25.3 & 4 & \\
\hline C & 29 & 0.36 & 778 & 6 & 9.54 & 6 & & & & \\
\hline $3 F$ & 32 & & 795 & 12 & 1.93 & 12 & 447 & 8.7 & 5 & \\
\hline C & 33 & 0.13 & 397 & 6 & 6.73 & 6 & & & & \\
\hline
\end{tabular}


Appendix G . (Continued).

\begin{tabular}{|c|c|c|c|c|c|c|c|c|c|c|}
\hline $\log$ ID & $\begin{array}{l}\text { MS } \\
\text { No. }\end{array}$ & $\begin{array}{c}\text { Fines } \\
\text { (fraction } \\
\text { of } \\
\text { total wt) }\end{array}$ & $\begin{array}{l}{ }^{241} \mathrm{Am} \\
\text { dry wt } \\
\text { Bqkg-1 }^{-1} \\
\text { fraction }\end{array}$ & $\begin{array}{l}\% \\
\text { error }\end{array}$ & $\begin{array}{l}{ }^{241} \mathrm{Am} \\
\text { dry wt } \\
\mathrm{kBqm}^{-2} \\
\text { fraction }\end{array}$ & $\begin{array}{l}\% \\
\text { error }\end{array}$ & $\begin{array}{c}{ }^{241} \mathrm{Am} \\
\text { dry } \\
\text { Bqkg-1 }^{-1} \\
\text { total } \\
\text { sample }\end{array}$ & $\begin{array}{c}{ }^{241} \mathrm{Am} \\
\text { dry } \\
\mathrm{kBqm}^{-2} \\
\text { total } \\
\text { sample }\end{array}$ & $\begin{array}{l}\% \\
\text { error }\end{array}$ & $\begin{array}{c}{ }^{241} \mathrm{Am} / \\
{ }^{239} \mathrm{A40} \mathrm{Pu}\end{array}$ \\
\hline $4 \mathrm{~F}$ & 36 & & 189 & 6 & 3.42 & 6 & 173 & 5.0 & 5 & \\
\hline C & 37 & 0.62 & 146 & 6 & 1.62 & 6 & & & & \\
\hline $5 \mathrm{~F}$ & 40 & & 69 & 9 & 1.33 & 9 & 67 & 2.0 & 6 & \\
\hline C & 41 & 0.63 & 63 & 6 & 0.71 & 6 & & & & \\
\hline $6 \mathrm{~F}$ & 44 & & 49 & 14 & 0.85 & 14 & 40 & 1.2 & 11 & \\
\hline C & 45 & 0.59 & 28 & 11 & 0.33 & 11 & & & & \\
\hline 6/15/79-1F & 48 & & 39 & 8 & 1.01 & 8 & 39 & 1.1 & 8 & \\
\hline C & 49 & 0.96 & 37 & 25 & 0.04 & 25 & & & & \\
\hline $2 \mathrm{~F}$ & 52 & & 111 & 7 & 1.90 & 7 & 113 & 2.9 & 5 & \\
\hline C & 53 & 0.65 & 115 & 8 & 1.04 & 8 & & & & \\
\hline $3 F$ & 56 & & 66 & 9 & 0.98 & 9 & 75 & 2.0 & 5 & \\
\hline C & 57 & 0.57 & 86 & 6 & 0.97 & 6 & & & & \\
\hline $4 \mathrm{~F}$ & 60 & & 119 & 9 & 1.34 & 9 & 111 & 3.0 & 6 & \\
\hline C & 61 & 0.42 & 105 & 7 & 1.63 & 7 & & & & \\
\hline $5 \mathrm{~F}$ & 64 & & 317 & 6 & 0.60 & 6 & 235 & 3.3 & 6 & \\
\hline C & 65 & 0.13 & 222 & 7 & 2.69 & 7 & & & & \\
\hline $6 \mathrm{~F}$ & 68 & & 131 & 6 & 2.54 & 6 & 119 & 4.8 & 5 & \\
\hline C & 69 & 0.48 & 107 & 7 & 2.25 & 7 & & & & \\
\hline $7 F$ & 72 & & 69 & 11 & 0.72 & 11 & 59 & 1.6 & 7 & \\
\hline C & 73 & 0.38 & 53 & 9 & 0.89 & 9 & & & & \\
\hline $8 \mathrm{~F}$ & 76 & & 68 & 6 & 1.28 & 6 & 59 & 1.7 & 5 & \\
\hline C & 77 & 0.67 & 40 & 8 & 0.37 & 8 & & & & \\
\hline $9 F$ & 80 & & 44 & 17 & 0.38 & 17 & 34 & 0.9 & 9 & \\
\hline C & 81 & 0.33 & 29 & 8 & 0.51 & 8 & & & & \\
\hline $10 \mathrm{~F}$ & 84 & & 176 & 9 & 3.01 & 9 & 137 & 4.0 & 7 & \\
\hline C & 85 & 0.59 & 82 & 5 & 0.99 & 5 & & & & \\
\hline $11 \mathrm{~F}$ & 88 & & 160 & 10 & 2.60 & 10 & 152 & 3.8 & 7 & 0.40 \\
\hline C & 89 & 0.64 & 137 & 7 & 1.24 & 7 & & & & \\
\hline $12 \mathrm{~F}$ & 92 & & 100 & 14 & 0.99 & 14 & 105 & 2.3 & 7 & \\
\hline C & 93 & 0.45 & 109 & 7 & 1.29 & 7 & & & & \\
\hline $13 \mathrm{~F}$ & 96 & & 197 & 16 & 3.51 & 16 & 173 & 4.7 & 12 & \\
\hline C & 97 & 0.66 & 128 & 6 & 1.19 & 6 & & & & \\
\hline $14 \mathrm{~F}$ & 7600 & & 336 & 8 & 1.47 & 8 & 275 & 4.9 & 5 & \\
\hline C & 1 & 0.24 & 255 & 7 & 3.45 & 7 & & & & \\
\hline $15 \mathrm{~F}$ & 4 & & 211 & 6 & 2.99 & 6 & 170 & 4.3 & 4 & 0.54 \\
\hline C & 5 & 0.56 & 117 & 5 & 1.32 & 5 & & & & \\
\hline $16 \mathrm{~F}$ & 8 & & 1097 & 7 & 2.09 & 7 & 615 & 9.5 & 5 & 0.71 \\
\hline C & 9 & 0.12 & 547 & 6 & 7.36 & 6 & & & & \\
\hline
\end{tabular}


Appendix G . (Continued).

\begin{tabular}{|c|c|c|c|c|c|c|c|c|c|c|}
\hline $\log$ ID & $\begin{array}{l}\text { MS } \\
\text { No. }\end{array}$ & $\begin{array}{c}\text { Fines } \\
\text { (fraction } \\
\text { of } \\
\text { total wt) }\end{array}$ & $\begin{array}{l}{ }^{241} \mathrm{Am} \\
\text { dry wt } \\
\text { Bqkg }^{-1} \\
\text { fraction }\end{array}$ & $\begin{array}{l}\% \\
\text { error }\end{array}$ & $\begin{array}{l}{ }^{241} \mathrm{Am} \\
\text { dry wt } \\
\mathrm{kBqm}^{-2} \\
\text { fraction }\end{array}$ & $\begin{array}{l}\% \\
\text { error }\end{array}$ & $\begin{array}{l}{ }^{241} \text { Am } \\
\text { dry } \\
\text { Bqkg-1 } \\
\text { total } \\
\text { sample }\end{array}$ & $\begin{array}{l}{ }^{241} \mathrm{Am} \\
\text { dry } \\
\mathrm{kBqm}^{-2} \\
\text { total } \\
\text { sample }\end{array}$ & $\begin{array}{l}\% \\
\text { error }\end{array}$ & $\begin{array}{c}{ }^{241} \mathrm{Am} / \\
{ }^{239+240} \mathrm{Pu}\end{array}$ \\
\hline $17 \mathrm{~F}$ & 12 & & 115 & 100 & 0.10 & 100 & 230 & 2.4 & 7 & \\
\hline C & 13 & 0.08 & 241 & 6 & 2.34 & 6 & & & & \\
\hline $18 \mathrm{~F}$ & 16 & & 385 & 14 & 0.28 & 14 & 288 & 3.3 & 13 & \\
\hline $\mathrm{C}$ & 17 & 0.06 & 281 & 14 & 2.99 & 14 & & & & \\
\hline $6 / 16 / 79-1 F$ & 20 & & 283 & 7 & 1.91 & 7 & 234 & 4.1 & 5 & \\
\hline $\mathrm{C}$ & 21 & 0.39 & 202 & 6 & 2.16 & 6 & & & & \\
\hline $2 \mathrm{~F}$ & 22 & & 4193 & 8 & 95.69 & 8 & 3950 & 99.7 & 8 & 0.87 \\
\hline $\mathrm{C}$ & 23 & 0.90 & 1659 & 7 & 4.01 & 7 & & & & \\
\hline $3 F$ & 24 & & 1799 & 5 & 26.23 & 5 & 1597 & 32.8 & 4 & \\
\hline $\mathrm{C}$ & 25 & 0.71 & 1104 & 7 & 6.60 & 7 & & & & \\
\hline $4 \mathrm{~F}$ & 26 & & 3037 & 9 & 34.77 & 9 & 2081 & 47.5 & 7 & \\
\hline C & 27 & 0.50 & 1117 & 8 & 12.68 & 8 & & & & \\
\hline $5 \mathrm{~F}$ & 28 & & 3944 & 6 & 29.91 & 6 & 2493 & 40.4 & 5 & \\
\hline $\mathrm{C}$ & 29 & 0.47 & 1214 & 7 & 10.44 & 7 & & & & \\
\hline $6 \mathrm{~F}$ & 30 & & 613 & 6 & 13.06 & 6 & 583 & 14.5 & 5 & \\
\hline $\mathrm{C}$ & 31 & 0.86 & 406 & 10 & 1.47 & 10 & & & & \\
\hline $7 F$ & 32 & & 3556 & 5 & 33.93 & 5 & 2267 & 48.9 & 4 & \\
\hline C & 33 & 0.44 & 1245 & 6 & 14.99 & 6 & & & & \\
\hline $8 \mathrm{~F}$ & 36 & & 7589 & 6 & 186.73 & 6 & 7603 & 187.7 & 6 & 0.75 \\
\hline C & 37 & 1.00 & 12185 & 7 & 0.93 & 7 & & & & \\
\hline $9 \mathrm{~F}$ & 38 & & 3426 & 6 & 80.11 & 6 & 3397 & 80.9 & 6 & 0.84 \\
\hline C & 39 & 0.98 & 1811 & 5 & 0.78 & 5 & & & & \\
\hline $10 \mathrm{~F}$ & 42 & & 1029 & 8 & 23.16 & 8 & 1019 & 24.3 & 8 & \\
\hline$C$ & 43 & 0.95 & 857 & 6 & 1.11 & 6 & & & & \\
\hline $11 \mathrm{~F}$ & 46 & & 1894 & 12 & 19.76 & 12 & 1238 & 29.0 & 8 & \\
\hline $\mathrm{C}$ & 47 & 0.45 & 710 & 7 & 9.21 & 7 & & & & \\
\hline $12 \mathrm{~F}$ & 50 & & 4426 & 6 & 17.01 & 6 & 2049 & 35.6 & 5 & 0.80 \\
\hline C & 51 & 0.22 & 1374 & 7 & 18.61 & 7 & & & & \\
\hline $13 \mathrm{~F}$ & 54 & & 736 & 11 & 4.04 & 11 & 705 & 12.0 & 5 & 0.64 \\
\hline $\mathrm{C}$ & 55 & 0.32 & 691 & 5 & 7.96 & 5 & & & & \\
\hline $14 \mathrm{~F}$ & 58 & & 1055 & 14 & 1.02 & 14 & 81 & 1.0 & 14 & \\
\hline$C$ & 59 & 0.08 & & & & & & & & \\
\hline $15 \mathrm{~F}$ & 62 & & 999 & 8 & 0.53 & 8 & 1029 & 9.5 & 6 & \\
\hline C & 63 & 0.06 & 1031 & 6 & 8.94 & 6 & & & & \\
\hline $16 \mathrm{~F}$ & 66 & & 904 & 8 & 0.84 & 8 & 552 & 6.3 & 8 & \\
\hline$C$ & 67 & 0.08 & 521 & 9 & 5.44 & 9 & & & & \\
\hline $17 \mathrm{~F}$ & 70 & & 1326 & 9 & 2.07 & 9 & 867 & 10.0 & 5 & \\
\hline $\mathrm{C}$ & 71 & 0.13 & 795 & 6 & 7.95 & 6 & & & & \\
\hline
\end{tabular}


Appendix G . (Continued).

\begin{tabular}{|c|c|c|c|c|c|c|c|c|c|c|}
\hline $\log I D$ & $\begin{array}{l}\text { MS } \\
\text { No. }\end{array}$ & $\begin{array}{c}\begin{array}{c}\text { Fines } \\
\text { (fraction } \\
\text { of } \\
\text { total wt) }\end{array}\end{array}$ & $\begin{array}{l}{ }^{241} \mathrm{Am} \\
\text { dry wt } \\
\mathrm{Bqkg}^{-1} \\
\text { fraction }\end{array}$ & $\begin{array}{l}\% \\
\text { error }\end{array}$ & $\begin{array}{l}{ }^{241} \mathrm{Am} \\
\text { dry wt } \\
\mathrm{kBqm}^{-2} \\
\text { fraction }\end{array}$ & $\begin{array}{l}\% \\
\text { error }\end{array}$ & $\begin{array}{l}{ }^{241} \text { Am } \\
\text { dry } \\
\text { Bqkg-1 } \\
\text { total } \\
\text { sample }\end{array}$ & $\begin{array}{l}{ }^{241} \mathrm{Am} \\
\mathrm{dry}^{-} \\
\mathrm{kBqm}^{-2} \\
\text { total } \\
\text { sample }\end{array}$ & $\begin{array}{l}\% \\
\text { error }\end{array}$ & $\begin{array}{c}{ }^{241} \mathrm{Am} / \\
{ }^{239+240} \mathrm{Pu}\end{array}$ \\
\hline $18 \mathrm{~F}$ & 74 & & 5115 & 5 & 4.69 & 5 & 1787 & 17.1 & 5 & 1.00 \\
\hline C & 75 & 0.10 & 1434 & 7 & 12.41 & 7 & & & & \\
\hline $19 \mathrm{~F}$ & 78 & & 2984 & 5 & 17.72 & 5 & 1612 & 25.4 & 4 & \\
\hline C & 79 & 0.38 & 782 & 5 & 7.67 & 5 & & & & \\
\hline $20 \mathrm{~F}$ & 82 & & 3289 & 11 & 3.01 & 11 & 1403 & 14.6 & 5 & \\
\hline C & 83 & 0.09 & 1221 & 5 & 11.60 & 5 & & & & \\
\hline $21 \mathrm{~F}$ & 86 & & 3559 & 7 & 6.64 & 7 & 1439 & 20.2 & 4 & \\
\hline $\mathrm{C}$ & 87 & 0.13 & 1113 & 5 & 13.52 & 5 & & & & \\
\hline $22 \mathrm{~F}$ & 90 & & 3756 & 5 & 38.54 & 5 & 2354 & 50.2 & 4 & \\
\hline C & 91 & 0.48 & 1052 & 5 & 11.62 & 5 & & & & \\
\hline $23 \mathrm{~F}$ & 94 & & 4189 & 5 & 61.54 & 5 & 2786 & 76.1 & 4 & \\
\hline C & 95 & 0.54 & 1153 & 9 & 14.56 & 9 & & & & \\
\hline 6/17/79-1F & 98 & & 34 & 36 & 0.14 & 36 & 45 & 1.2 & 10 & \\
\hline C & 99 & 0.16 & 48 & 10 & 1.07 & 10 & & & & \\
\hline $2 \mathrm{~F}$ & 7700 & & 19 & 30 & 0.18 & 30 & 31 & 0.9 & 11 & 0.70 \\
\hline $\mathrm{C}$ & 1 & 0.31 & 36 & 11 & 0.72 & 11 & & & & \\
\hline $3 F$ & 4 & & 16 & 100 & 0.07 & 100 & 24 & 0.7 & 13 & \\
\hline $\mathrm{C}$ & 5 & 0.14 & 25 & 9 & 0.62 & 9 & & & & \\
\hline $4 \mathrm{~F}$ & 8 & & 25 & 23 & 0.12 & 23 & 25 & 0.7 & 9 & \\
\hline $\mathrm{C}$ & 9 & 0.19 & 25 & 10 & 0.55 & 10 & & & & \\
\hline $5 \mathrm{~F}$ & 12 & & 33 & 8 & 0.43 & 8 & 21 & 0.6 & 7 & \\
\hline C & 13 & 0.46 & 11 & 14 & 0.17 & 14 & & & & \\
\hline $6 \mathrm{~F}$ & 16 & & 40 & 7 & 0.86 & 7 & 39 & 1.1 & 6 & \\
\hline C & 17 & 0.76 & 38 & 9 & 0.27 & 9 & & & & \\
\hline $7 F$ & 20 & & 29 & 7 & 0.56 & 7 & 38 & 1.1 & 6 & \\
\hline C & 21 & 0.67 & 56 & 11 & 0.54 & 11 & & & & \\
\hline $8 \mathrm{~F}$ & 24 & & 26 & 18 & 0.56 & 18 & 25 & 0.9 & 12 & \\
\hline C & 25 & 0.65 & 25 & 10 & 0.30 & 10 & & & & \\
\hline & & & & & & & \multicolumn{4}{|c|}{ mean ${ }^{241} \mathrm{Am} / 239+240 \mathrm{Pu} 0.69 \pm 0.17$} \\
\hline
\end{tabular}

$\mathrm{F}=$ fines; $\mathrm{C}=$ coarse fraction 



\section{Appendix $\mathbf{H}$}

Concentration of ${ }^{241} \mathrm{Am}$ in Fine and Coarse Fractions from Surface $(0-4 \mathrm{~cm})$ Sections of Sediment Samples Collected from Bikini Lagoon During 4-6/1979 and Ratio of Inventory in 0-4 cm Section to Inventory in 0-2 cm Section 

Appendix H. Concentration of ${ }^{241} \mathrm{Am}$ in fine and coarse fractions from surface $(0-4 \mathrm{~cm})$ sections of sediment samples collected from Bikini lagoon during 4-6/1979 and ratio of inventory in 0-4 cm section to inventory in $0-2 \mathrm{~cm}$ section .

\begin{tabular}{|c|c|c|c|c|c|c|c|c|c|c|}
\hline $\log I D$ & $\begin{array}{l}\text { MS } \\
\text { No. }\end{array}$ & $\begin{array}{c}\text { Fines } \\
\text { (fraction } \\
\text { of } \\
\text { total wt) }\end{array}$ & $\begin{array}{c}{ }^{241} \mathrm{Am} \\
\text { dry wt } \\
\text { Bqkg }^{-1} \\
\text { fraction }\end{array}$ & $\begin{array}{l}\% \\
\text { error }\end{array}$ & $\begin{array}{l}{ }^{241} \mathrm{Am} \\
\text { dry wt } \\
\mathrm{kBqm}^{-2} \\
\text { fraction }\end{array}$ & $\begin{array}{c}\% \\
\text { error }\end{array}$ & $\begin{array}{l}{ }^{241} \mathrm{Am} \\
\text { dry } \\
\text { Bqkg-1 } \\
\text { total } \\
\text { sample }\end{array}$ & $\begin{array}{l}{ }^{241} \mathrm{Am} \\
\text { dry } \\
\mathrm{kBqm}^{-2} \\
\text { total } \\
\text { sample }\end{array}$ & $\begin{array}{l}\% \\
\text { error }\end{array}$ & $\begin{array}{c}\text { Inventory } \\
\text { ratio } \\
0-4 \mathrm{~cm} / \\
0-2 \mathrm{~cm} \\
\text { depth }\end{array}$ \\
\hline $4 / 22 / 79-3 F$ & 7406 & & 94 & 6 & 2.2 & 6 & 83 & 3.6 & 9 & 1.5 \\
\hline C & 7 & 0.54 & 70 & 11 & 1.4 & 11 & & & & \\
\hline $4 \mathrm{~F}$ & 10 & & 45 & 11 & 1.0 & 11 & 48 & 2.6 & 9 & 1.7 \\
\hline C & 11 & 0.42 & 51 & 8 & 1.6 & 8 & & & & \\
\hline $5 \mathrm{~F}$ & 14 & & 151 & 6 & 2.0 & 6 & 172 & 6.2 & 7 & 2.8 \\
\hline $\mathrm{C}$ & 15 & 0.37 & 184 & 7 & 4.2 & 7 & & & & \\
\hline $10 \mathrm{~F}$ & 26 & & 291 & 17 & 2.4 & 17 & 187 & 7.7 & 9 & 2.2 \\
\hline C & 27 & 0.21 & 160 & 6 & 5.2 & 6 & & & & \\
\hline $11 \mathrm{~F}$ & 30 & & 718 & 10 & 0.9 & 10 & 587 & 12.0 & 6 & 2.0 \\
\hline C & 31 & 0.06 & 578 & 6 & 11.1 & 6 & & & & \\
\hline $12 \mathrm{~F}$ & 34 & & 512 & 6 & 1.0 & 6 & 493 & 11.7 & 6 & 2.5 \\
\hline C & 35 & 0.08 & 491 & 6 & 10.7 & 6 & & & & \\
\hline $13 \mathrm{~F}$ & 38 & & 178 & 31 & 0.2 & 31 & 368 & 7.1 & 9 & 1.2 \\
\hline C & 39 & 0.06 & 380 & 5 & 6.9 & 5 & & & & \\
\hline $4 / 23 / 79-1 F$ & 44 & & 139 & 15 & 3.1 & 15 & 104 & 5.9 & 10 & 1.6 \\
\hline C & 45 & 0.39 & 81 & 5 & 2.8 & 5 & & & & \\
\hline $2 \mathrm{~F}$ & 48 & & 247 & 13 & 2.7 & 13 & 319 & 12.1 & 8 & 2.5 \\
\hline C & 49 & 0.29 & 349 & 5 & 9.4 & 5 & & & & \\
\hline $3 F$ & 52 & & 74 & 7 & 2.1 & 7 & 65 & 3.8 & 7 & 2.0 \\
\hline $\mathrm{C}$ & 53 & 0.48 & 58 & 7 & 1.7 & 7 & & & & \\
\hline $4 / 24 / 79-1 F$ & 56 & & 53 & 7 & 1.5 & 7 & 52 & 2.8 & 7 & 1.8 \\
\hline C & 57 & 0.51 & 50 & 7 & 1.3 & 7 & & & & \\
\hline $2 \mathrm{Fa}$ & 60 & & 437 & 8 & 6.9 & 8 & 307 & 12.5 & 6 & 3.6 \\
\hline C & 61 & 0.39 & 224 & 5 & 5.5 & 5 & & & & \\
\hline $2 \mathrm{Fb}$ & 64 & & 1077 & 5 & 5.0 & 5 & 598 & 16.2 & 6 & 2.0 \\
\hline C & 65 & 0.17 & 500 & 6 & 11.2 & 6 & & & & \\
\hline $3 \mathrm{Fa}$ & 68 & & 1955 & 6 & 4.1 & 6 & 706 & 15.0 & 6 & 5.4 \\
\hline C & 69 & 0.10 & 567 & 6 & 10.9 & 6 & & & & \\
\hline $3 \mathrm{Fb}$ & 72 & & 608 & 43 & 0.3 & 43 & 433 & 8.4 & 8 & 1.5 \\
\hline C & 73 & 0.03 & 427 & 4 & 8.1 & 4 & & & & \\
\hline $4 \mathrm{~F}$ & 76 & & 287 & 8 & 3.6 & 8 & 209 & 9.3 & 5 & 1.6 \\
\hline C & 77 & 0.29 & 178 & 4 & 5.7 & 4 & & & & \\
\hline $5 \mathrm{~F}$ & 80 & & 596 & 10 & 0.6 & 10 & 545 & 11.7 & 6 & 2.2 \\
\hline C & 81 & 0.05 & 543 & 6 & 11.1 & 6 & & & & \\
\hline $6 \mathrm{~F}$ & 84 & & 1289 & 6 & 5.2 & 6 & 744 & 18.2 & 6 & 2.6 \\
\hline $\mathrm{C}$ & 85 & 0.17 & 636 & 6 & 13.0 & 6 & & & & \\
\hline
\end{tabular}


Appendix H. (Continued).

\begin{tabular}{|c|c|c|c|c|c|c|c|c|c|c|}
\hline $\log$ ID & $\begin{array}{l}\text { MS } \\
\text { No. }\end{array}$ & $\begin{array}{c}\text { Fines } \\
\text { (fraction } \\
\text { of } \\
\text { total wt) }\end{array}$ & $\begin{array}{c}{ }^{241} \mathrm{Am} \\
\text { dry wt } \\
\text { Bqkg-1 }^{-1} \\
\text { fraction }\end{array}$ & $\begin{array}{l}\% \\
\text { error }\end{array}$ & $\begin{array}{l}{ }^{241} \mathrm{Am} \\
\text { dry } w t \\
\mathrm{kBqm}^{-2} \\
\text { fraction }\end{array}$ & $\begin{array}{c}\% \\
\text { error }\end{array}$ & $\begin{array}{c}{ }^{241} \mathrm{Am} \\
\text { dry } \\
\text { Bqkg-1 }^{-1} \\
\text { total } \\
\text { sample }\end{array}$ & $\begin{array}{l}{ }^{241} \mathrm{Am} \\
\text { dry } \\
\mathrm{kBqm}^{-2} \\
\text { total } \\
\text { sample }\end{array}$ & error & $\begin{array}{c}\text { Inventory } \\
\text { ratio } \\
0-4 \mathrm{~cm} / \\
0-2 \mathrm{~cm} \\
\text { depth }\end{array}$ \\
\hline $7 F$ & 88 & & 863 & 16 & 1.5 & 16 & 557 & 12.0 & 7 & 2.0 \\
\hline C & 89 & 0.08 & 531 & 5 & 10.5 & 5 & & & & \\
\hline $8 \mathrm{~F}$ & 9094 & & 264 & 8 & 8.5 & 8 & 293 & 17.1 & 7 & 3.4 \\
\hline C & 9095 & 0.55 & 327 & 5 & 8.6 & 5 & & & & \\
\hline $10 \mathrm{~F}$ & 98 & & 348 & 11 & 15.1 & 11 & 315 & 17.9 & 10 & 2.0 \\
\hline C & 99 & 0.76 & 208 & 6 & 2.9 & 6 & & & & \\
\hline $11 \mathrm{~F}$ & 7502 & & 330 & 6 & 14.9 & 6 & 291 & 20.1 & 6 & 2.4 \\
\hline C & 3 & 0.65 & 217 & 7 & 5.2 & 7 & & & & \\
\hline $12 \mathrm{~F}$ & 6 & & 951 & 5 & 37.6 & 5 & 915 & 47.5 & 6 & 2.1 \\
\hline $\mathrm{C}$ & 7 & 0.76 & 799 & 7 & 10.0 & 7 & & & & \\
\hline $13 \mathrm{~F}$ & 9096 & & 918 & 12 & 6.3 & 12 & 354 & 16.5 & 10 & 2.0 \\
\hline C & 9097 & 0.15 & 256 & 9 & 10.2 & 9 & & & & \\
\hline $15 \mathrm{~F}$ & 14 & & 9081 & 7 & 381.2 & 7 & 7443 & 396.8 & 7 & 2.4 \\
\hline $\mathrm{C}$ & 15 & 0.79 & 1377 & 8 & 15.6 & 8 & & & & \\
\hline $15 \mathrm{bF}$ & 16 & & 10104 & 7 & 356.3 & 7 & 7149 & 394.1 & 6 & \\
\hline C & 17 & 0.64 & 1905 & 5 & 37.8 & 5 & & & & \\
\hline $17 \mathrm{~F}$ & 22 & & 3110 & 9 & 150.1 & 9 & 3112 & 150.9 & 9 & 2.1 \\
\hline C & 23 & 1.00 & 3648 & 8 & 0.8 & 8 & & & & \\
\hline $4 / 25 / 79-2 F$ & 30 & & 1920 & 14 & 35.8 & 14 & 974 & 44.6 & 10 & 1.8 \\
\hline $\mathrm{C}$ & 31 & 0.41 & 324 & 7 & 8.8 & 7 & & & & \\
\hline $3 F$ & 34 & & 1281 & 6 & 7.2 & 6 & 463 & 18.8 & 6 & 2.2 \\
\hline C & 35 & 0.14 & 332 & 6 & 11.6 & 6 & & & & \\
\hline $4 \mathrm{~F}$ & 38 & & 174 & 7 & 6.1 & 7 & 148 & 8.0 & 7 & 1.6 \\
\hline C & 39 & 0.65 & 100 & 7 & 1.9 & 7 & & & & \\
\hline $5 \mathrm{~F}$ & 42 & & 65 & 12 & 2.4 & 12 & 76 & 4.6 & 12 & 2.3 \\
\hline C & 43 & 0.60 & 92 & 11 & 2.2 & 11 & & & & \\
\hline $6 \mathrm{~F}$ & 46 & & 53 & 11 & 2.1 & 11 & 73 & 4.2 & 10 & 3.5 \\
\hline C & 47 & 0.68 & 114 & 8 & 2.1 & 8 & & & & \\
\hline 6/15/79-1F & 50 & & 37 & 8 & 1.6 & 8 & 36 & 1.6 & 8 & 1.4 \\
\hline C & 51 & 0.97 & 16 & & 0.0 & & & & & \\
\hline $2 \mathrm{~F}$ & 54 & & 84 & 10 & 3.0 & 10 & 87 & 4.6 & 10 & 1.6 \\
\hline C & 55 & 0.66 & 92 & 11 & 1.7 & 11 & & & & \\
\hline $3 F$ & 58 & & 90 & 6 & 2.6 & 6 & 87 & 4.2 & 6 & 2.1 \\
\hline C & 59 & 0.60 & 81 & 6 & 1.6 & 6 & & & & \\
\hline $4 \mathrm{~F}$ & 62 & & 105 & 7 & 1.3 & 7 & 88 & 3.9 & 6 & 1.3 \\
\hline C & 63 & 0.28 & 81 & 6 & 2.6 & 6 & & & & \\
\hline $5 \mathrm{~F}$ & 66 & & 274 & 10 & 2.8 & 10 & 980 & 30.8 & 7 & 9.3 \\
\hline C & 67 & 0.32 & 1319 & 4 & 28.0 & 4 & & & & \\
\hline $6 \mathrm{~F}$ & 70 & & 109 & 8 & 4.0 & 8 & 101 & 5.6 & 8 & 1.2 \\
\hline C & 71 & 0.65 & 85 & 8 & 1.7 & 8 & & & & \\
\hline $7 F$ & 74 & & 69 & 11 & 1.7 & 11 & 50 & 2.9 & 9 & 1.8 \\
\hline C & 75 & 0.43 & 36 & 7 & 1.2 & 7 & & & & \\
\hline 9F & 82 & & 36 & 31 & 0.6 & 31 & 30 & 1.5 & 20 & 1.7 \\
\hline C & 83 & 0.33 & 27 & 10 & 0.9 & 10 & & & & \\
\hline $10 \mathrm{~F}$ & 86 & & 177 & 7 & 5.0 & 7 & 158 & 7.3 & 7 & 1.8 \\
\hline
\end{tabular}


Appendix H. (Continued).

\begin{tabular}{|c|c|c|c|c|c|c|c|c|c|c|}
\hline $\log$ ID & $\begin{array}{l}\text { MS } \\
\text { No. }\end{array}$ & $\begin{array}{c}\text { Fines } \\
\text { (fraction } \\
\text { of } \\
\text { total wt) }\end{array}$ & $\begin{array}{c}{ }^{241} \mathrm{Am} \\
\text { dry } w t \\
\text { Bqkg }^{-1} \\
\text { fraction }\end{array}$ & $\begin{array}{l}\% \\
\text { error }\end{array}$ & $\begin{array}{l}{ }^{241} \mathrm{Am} \\
\text { dry } w \mathrm{t} \\
\mathrm{kBqm}^{-2} \\
\text { fraction }\end{array}$ & $\begin{array}{c}\% \\
\text { error }\end{array}$ & $\begin{array}{l}{ }^{241} \mathrm{Am} \\
\text { dry } \\
\text { Bqkg-1 }^{-1} \\
\text { total } \\
\text { sample }\end{array}$ & $\begin{array}{l}{ }^{241} \mathrm{Am} \\
\text { dry } \\
\mathrm{kBqm}^{-2} \\
\text { total } \\
\text { sample }\end{array}$ & error & $\begin{array}{c}\text { Inventory } \\
\text { ratio } \\
0-4 \mathrm{~cm} / \\
0-2 \mathrm{~cm} \\
\text { depth }\end{array}$ \\
\hline C & 87 & 0.61 & 128 & 6 & 2.3 & 6 & & & & \\
\hline $11 \mathrm{~F}$ & 90 & & 142 & 8 & 5.0 & 8 & 134 & 7.4 & 8 & 1.9 \\
\hline C & 91 & 0.64 & 121 & 7 & 2.4 & 7 & & & & \\
\hline $12 \mathrm{~F}$ & 94 & & 181 & 6 & 4.0 & 6 & 214 & 9.7 & 6 & 4.2 \\
\hline C & 95 & 0.49 & 246 & 6 & 5.7 & 6 & & & & \\
\hline $13 \mathrm{~F}$ & 98 & & 161 & 11 & 6.0 & 11 & 158 & 7.6 & 10 & 1.6 \\
\hline C & 99 & 0.78 & 147 & 6 & 1.5 & 6 & & & & \\
\hline $14 \mathrm{~F}$ & 7602 & & 305 & 12 & 2.6 & 12 & 272 & 8.2 & 9 & 1.7 \\
\hline C & 3 & 0.28 & 260 & 7 & 5.7 & 7 & & & & \\
\hline $15 \mathrm{~F}$ & 6 & & 227 & 10 & 4.5 & 10 & 221 & 9.0 & 8 & 2.1 \\
\hline C & 7 & 0.48 & 214 & 5 & 4.5 & 5 & & & & \\
\hline $16 \mathrm{~F}$ & 10 & & 833 & 5 & 8.1 & 5 & 658 & 20.1 & 6 & 2.1 \\
\hline $\mathrm{C}$ & 11 & 0.32 & 576 & 6 & 11.9 & 6 & & & & \\
\hline $17 \mathrm{~F}$ & 14 & & 200 & 29 & 0.3 & 29 & 197 & 3.9 & 10 & 1.6 \\
\hline $\mathrm{C}$ & 15 & 0.07 & 196 & 7 & 3.6 & 7 & & & & \\
\hline $18 \mathrm{~F}$ & 18 & & 867 & 8 & 6.6 & 8 & 473 & 12.3 & 7 & 3.7 \\
\hline $\mathrm{C}$ & 19 & 0.29 & 308 & 7 & 5.6 & 7 & & & & \\
\hline 6/16/79-7F & 34 & & 4593 & 5 & 75.4 & 5 & 2643 & 99.7 & 10 & 2.0 \\
\hline C & 35 & 0.44 & 1141 & 13 & 24.3 & 13 & & & & \\
\hline $9 \mathrm{~F}$ & 40 & & 3362 & 8 & 123.2 & 8 & 3317 & 125.6 & 8 & 1.6 \\
\hline C & 41 & 0.97 & 1947 & 8 & 2.3 & 8 & & & & \\
\hline $10 \mathrm{~F}$ & 44 & & 1269 & 5 & 51.1 & 5 & 1266 & 52.9 & 5 & 2.2 \\
\hline $\mathrm{C}$ & 45 & 0.96 & 1201 & 8 & 1.8 & 8 & & & & \\
\hline $11 \mathrm{~F}$ & 48 & & 1750 & 11 & 34.9 & 11 & 1245 & 48.4 & 9 & 1.7 \\
\hline $\mathrm{C}$ & 49 & 0.51 & 713 & 6 & 13.5 & 6 & & & & \\
\hline $12 \mathrm{~F}$ & 52 & & 4237 & 7 & 47.1 & 7 & 1857 & 68.1 & 6 & 1.9 \\
\hline $\mathrm{C}$ & 53 & 0.30 & 823 & 6 & 21.1 & 6 & & & & \\
\hline $13 \mathrm{~F}$ & 56 & & 1053 & 8 & 8.3 & 8 & 716 & 22.3 & 7 & 1.9 \\
\hline C & 57 & 0.25 & 601 & 7 & 14.0 & 7 & & & & \\
\hline $14 \mathrm{~F}$ & 60 & & 2134 & 11 & 12.6 & 11 & 918 & 18.8 & 7 & \\
\hline C & 61 & 0.29 & 423 & 4 & 6.1 & 4 & & & & \\
\hline $15 \mathrm{~F}$ & 64 & & 0 & & 0.0 & & 800 & 14.7 & 6 & 1.5 \\
\hline C & 65 & 0.05 & 840 & 6 & 14.7 & 6 & & & & \\
\hline $16 \mathrm{~F}$ & 68 & & 856 & 6 & 2.1 & 6 & 600 & 11.2 & 7 & 1.8 \\
\hline C & 69 & 0.13 & 561 & 7 & 9.1 & 7 & & & & \\
\hline $17 \mathrm{~F}$ & 72 & & 1109 & 7 & 2.0 & 7 & 860 & 15.2 & 6 & 1.5 \\
\hline C & 73 & 0.10 & 832 & 6 & 13.2 & 6 & & & & \\
\hline $18 \mathrm{~F}$ & 76 & & 4330 & 9 & 5.0 & 9 & 1660 & 32.5 & 5 & 1.9 \\
\hline C & 77 & 0.06 & 1491 & 5 & 27.5 & 5 & & & & \\
\hline $19 \mathrm{~F}$ & 80 & & 2672 & 8 & 45.7 & 8 & 1934 & 64.7 & 10 & 2.5 \\
\hline C & 81 & 0.51 & 1161 & 11 & 19.0 & 11 & & & & \\
\hline $20 \mathrm{~F}$ & 84 & & 4452 & 6 & 8.8 & 6 & 1792 & 31.8 & 8 & 2.2 \\
\hline C & 85 & 0.11 & 1457 & 8 & 23.0 & 8 & & & & \\
\hline $21 \mathrm{~F}$ & 88 & & 2688 & 5 & 6.0 & 5 & 1185 & 23.7 & 6 & 1.2 \\
\hline C & 89 & 0.11 & 994 & 6 & 17.6 & 6 & & & & \\
\hline
\end{tabular}


Appendix H. (Continued).

\begin{tabular}{|c|c|c|c|c|c|c|c|c|c|c|}
\hline $\log$ ID & $\begin{array}{l}\text { MS } \\
\text { No. }\end{array}$ & $\begin{array}{c}\text { Fines } \\
\text { (fraction } \\
\text { of } \\
\text { total wt) }\end{array}$ & $\begin{array}{c}{ }^{241} \mathrm{Am} \\
\text { dry wt } \\
\text { Bqkg }^{-1} \\
\text { fraction }\end{array}$ & $\begin{array}{l}\% \\
\text { error }\end{array}$ & $\begin{array}{l}{ }^{241} \mathrm{Am} \\
\text { dry wt } \\
\text { kBqm }^{-2} \\
\text { fraction }\end{array}$ & $\begin{array}{c}\% \\
\text { error }\end{array}$ & $\begin{array}{c}{ }^{241} \mathrm{Am} \\
\text { dry } \\
\text { Bqkg-1 } \\
\text { total } \\
\text { sample }\end{array}$ & $\begin{array}{l}{ }^{241} \mathrm{Am} \\
\text { dry } \\
\mathrm{kBqm}^{-2} \\
\text { total } \\
\text { sample }\end{array}$ & $\begin{array}{l}\% \\
\text { error }\end{array}$ & $\begin{array}{c}\text { Inventory } \\
\text { ratio } \\
0-4 \mathrm{~cm} / \\
0-2 \mathrm{~cm} \\
\text { depth }\end{array}$ \\
\hline $22 \mathrm{~F}$ & 92 & & 3770 & 5 & 106.0 & 5 & 2770 & 128.8 & 5 & 2.6 \\
\hline C & 93 & 0.60 & 1241 & 5 & 22.8 & 5 & & & & \\
\hline $23 \mathrm{~F}$ & 96 & & 4767 & 6 & 138.1 & 6 & 3695 & 155.7 & 6 & 2.0 \\
\hline C & 97 & 0.69 & 1333 & 5 & 17.5 & 5 & & & & \\
\hline $6 / 17 / 79-2 F$ & 7702 & & 20 & 22 & 0.4 & 22 & 18 & 0.9 & 17 & 1.0 \\
\hline $\mathrm{C}$ & 3 & 0.42 & 16 & 12 & 0.5 & 12 & & & & \\
\hline $3 F$ & 6 & & 26 & & 0.1 & & 27 & 1.2 & 9 & 1.7 \\
\hline C & 7 & 0.11 & 27 & 9 & 1.1 & 9 & & & & \\
\hline $4 \mathrm{~F}$ & 10 & & 32 & 26 & 0.4 & 26 & 30 & 1.3 & 18 & 1.9 \\
\hline C & 11 & 0.26 & 29 & 14 & 1.0 & 14 & & & & \\
\hline $5 \mathrm{~F}$ & 14 & & 30 & 9 & 0.9 & 9 & 26 & 1.5 & 11 & 2.5 \\
\hline C & 15 & 0.52 & 21 & 12 & 0.6 & 12 & & & & \\
\hline $6 \mathrm{~F}$ & 18 & & 45 & 8 & 1.7 & 8 & 40 & 2.1 & 9 & 1.9 \\
\hline $\mathrm{C}$ & 19 & 0.71 & 26 & 11 & 0.4 & 11 & & & & \\
\hline $7 \mathrm{~F}$ & 22 & & 141 & 12 & 1.5 & 12 & 96 & 2.3 & 10 & 2.1 \\
\hline C & 23 & 0.43 & 62 & 8 & 0.8 & 8 & & & & \\
\hline $8 \mathrm{~F}$ & 26 & & 167 & 12 & 1.2 & 12 & 72 & 1.4 & 31 & 1.6 \\
\hline \multirow[t]{2}{*}{ C } & 27 & 0.36 & 18 & 38 & 0.2 & 38 & & & & \\
\hline & & & & & & & & $\begin{array}{l}\text { mean } \\
\text { median }\end{array}$ & & $\begin{array}{l}2.2 \pm 1.2 \\
2.0\end{array}$ \\
\hline
\end{tabular}

$\mathrm{F}=$ fines $; \mathrm{C}=$ coarse fraction 


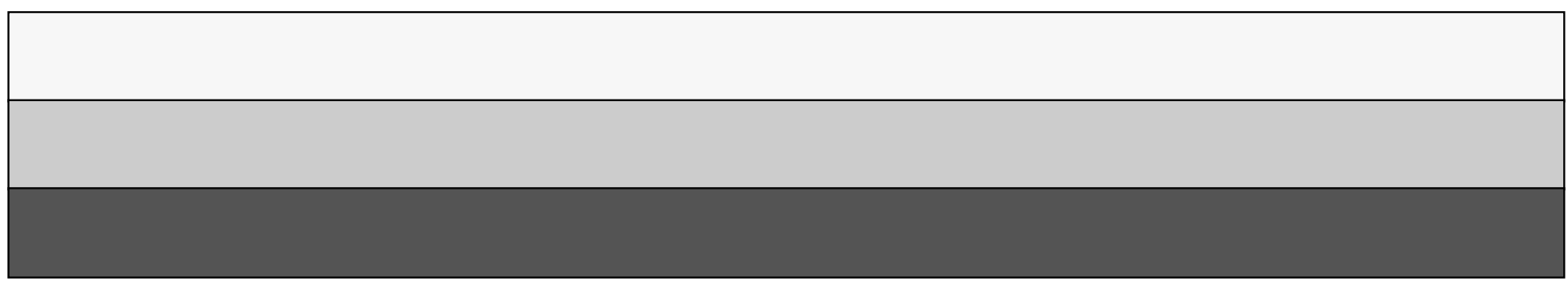

